NASATM- 88179

NASA Technical Memorandum 88179

Airborne Astronomy Program

Medium Altıtude Missıons Branch

Preprint Series 033

19860005753

\title{
Far Infrared and Submillimeter Brightness Temperatures of the Giant Planets
}

R.H. Hildebrand, R.R. Loewenstein, D.A. Harper, G.S. Orton, Jocelyn Keene, and S.E. Whitcomb

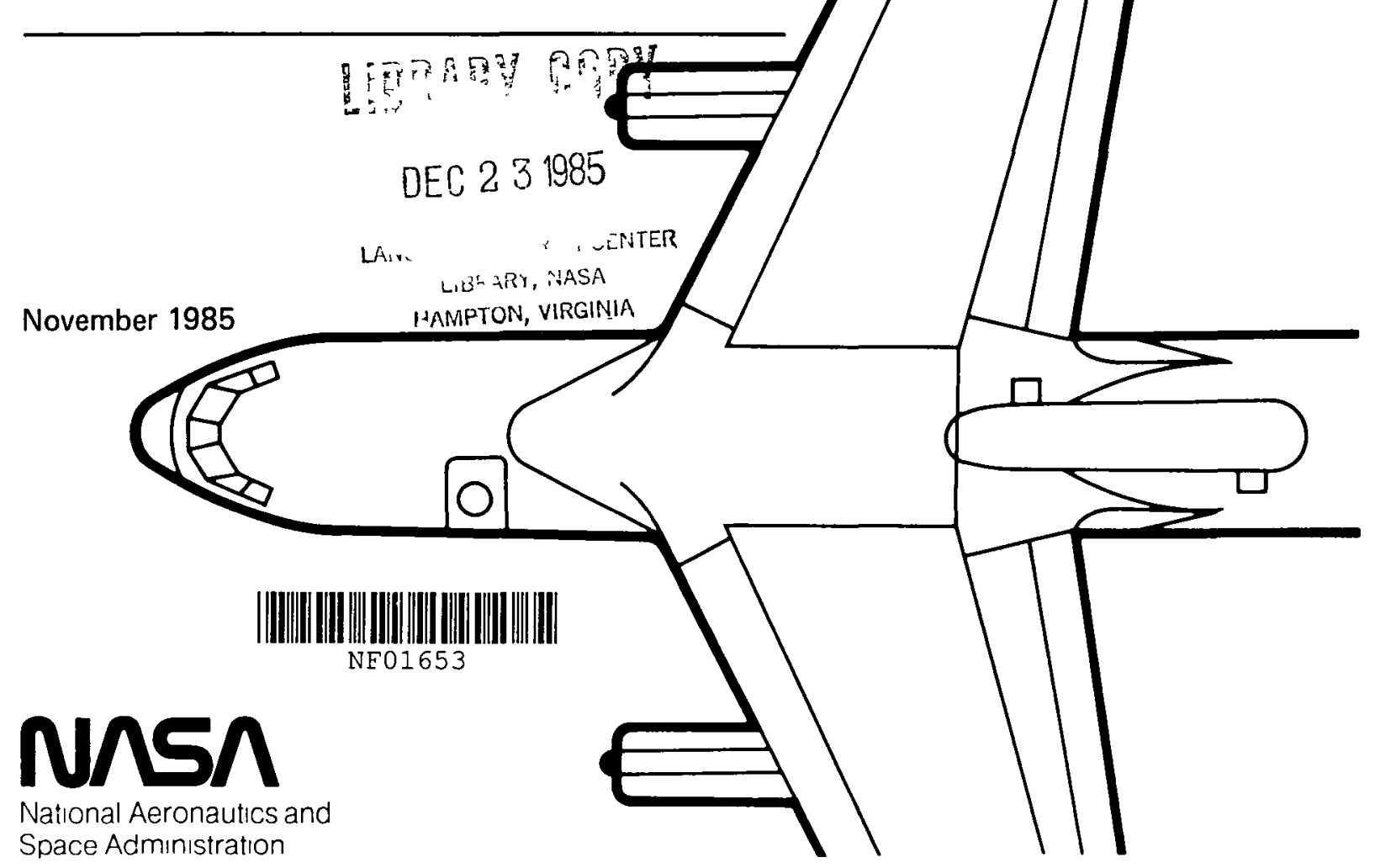




\section{Far Infrared and Submillimeter Brightness Temperatures of the Giant Planets}

R. H. HIldebrand,

R. F. Loewenstein,

D. A. Harper, Ames Research Center, Moffett Field, Californıa

G. S. Orton, Jet Propulsıon Laboratory, Pasadena, Calıfornıa

Jocelyn Keene,

S. E. Whitcomb, Ames Research Center, Moffett Fıeld, Calıfornia

November 1985

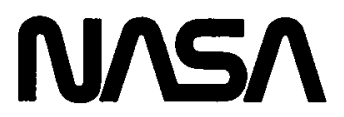

Natıonal Aeronautics and

Space Administration

Ames Research Center

Moffett Field Calıfornı 94035 


\section{FAR INFRARED AND SUBMILIIMETER BRIGHTNESS \\ TEMPERATURES OF THE GIANT PLANETS}

R. H. Hzldebrand $1,2,3$

R. F. Loewenstein $n^{1,2,4}$

D. A. Harper $1,2,4$

G. S. Orton ${ }^{5}$

Jocelyn Keene $1,2,6$

and

S. E. Whitcomb $1,2,6$

${ }^{1}$ Guest Observer: G. P. Ruiper Airborne Observatory, Ames Research Center, Moffett Field, CA 94035.

${ }^{2}$ Visiting Astronomer at the Infrared Telescope Facility, which 19 operated by the University of Hawaii under contract from the National Aeronautics and Space Adminzstration.

${ }^{3}$ Enrico Ferml Institute, Department of Astronomy and Astrophysics, and Department of Physics, The University of Chrcago, Chrcago, II 60637.

${ }^{4}$ Yerkes Observatory and Department of Astronomy and Astrophysics, The University of Chicago, Williams Bay, WI 53191.

${ }^{5}$ Jet Propulsion Laboratory, Calıfornia Institute of Technology, 4800 Oak Grove Driye, Pasadena, CA 91109.

6ivision of Physics, Mathematıcs, and Astronomy, Calıfornia Institute of Technology, Pasadena, CA 91125. 


\begin{abstract}
We have measured the brightness temperatures of Jupiter, Saturn. Uranus, and Neptune in the range 35- to 1000- $4 \mathrm{~m}$. The effectıve temperatures derived from the measurements, supplemented by shorter wavelength Voyager data for Jupiter and Saturn, are $126.8 \pm 4.5 \mathrm{~K}, 93.4$ $\pm 3.3 \mathrm{~K}, 58.3 \pm 2.0 \mathrm{~K}$, and $60.3 \pm 2.0 \mathrm{~K}$ respectıvely. We discuss the implications of the measurements for bolometric output and for atmospherıc structure and composition. The temperature spectrum of Jupıter shows a strong peak at - $350, \mu \mathrm{m}$ followed by a deep valley at 450- to 500-, um. Spectra derived from model atmospheres qualitatively reproduce these features but do not fit the data closely.
\end{abstract}




\section{INTRODUCTION}

Far-infrared and submillimeter photometric observations of the glant planets have three principal types of applications: first, the investigation of internal sources of energy; second, the invegtigation of planetary atmospheres; and third, the establishment of convenient reference objects for photometry of other sources.

The first direct measurements of the bolometric fluxes from Jupiter and saturn were the 1- to 300- $\mu \mathrm{m}$ arrborne observatzons made by Aumann, et al. (1969). They found that both planets emit substantially more power than they receive from the sun. However, the accuracy of the data was Iımıted by uncertainties in the atmospheric transmission and instrumental response function over the very broad passband and the fact that the spectra of the planets were very different from the spectra of the cool stars used as calıbration sources. Subsequent improvements in detectors and far infrared fllters allowed measurements in narrower passbands and observations of Uranus (Loewenstein et all. 1977a) and Neptune (Fazio et al. (1976); Loewenstern et al. 1977 b. Development of techniques for ground-based observations at submililmeter wavelengths permitted additional measurements between 300 um and 1000 tom (Loewenstein et al. 1977a; Whitcomb et al. 1979). Most of this subsequent work has been calibrated using the thermal model for Mars derıved by Neugebauer et al. (1971) from Marıner data and elaborated and extended by wright (1976), wright and Odenwald (1980), and simpson et al. (1981).

The IRIS experiment on Voyager has provided absolute spectrophotometry at wavelengths of $4.5-$ to $50-\mu \mathrm{m}$ of Juplter (Hanel et 
al. 1979) and Saturn (Hanel et al. 1982). Erlckson et al. (1978) made spectroscopic observations of Jupiter at $\lambda<100, \mathrm{~m}$. However, their data were callbrated against the moon, requiring a difflcult correction for flux into the extended wings of their beam.

The measurements presented here cover the range from 35 - to $1000-u \mathrm{~m}$ in relatively narrow bands. Roughly 508 of the total flux emitted by Jupiter, 658 by Saturn, and 928 by Uranus and Neptune falls with 1 n this range. The alrborne (35- to $330-\mu \mathrm{m}$ ) and ground-based (350- to $970-\mu \mathrm{m}$ ) observations were made at approximately the same times, durıng a perıod in which Saturn's rings were nearly edge-on as seen from the earth.

The opacities of the atmospheres of the grant planets at far infrared and submillimeter wavelengths come primarily from featureless, pressure-induced absorption in $\mathrm{H}_{2}$. Their atmospheres are probed to increasing depths by observations at increasing wavelengths. Although It is theoretically possible to derıve information about the maxing ratios of $\mathrm{H}_{2}$, He and $\mathrm{CH}_{4}$ from far infrared brightness temperatures, the required accuracies are probably greater than permitted by our current data and absolute calıbration. However, trace constituents (particularly ammonia in Jupiter) may produce spectral features which are distinguishable by their effect on the shape of the spectra over limited wavelength zntervals.

In the following sections we present the observations and Instrumentation (II); the data reduction, including corrections, calıbration, and planptafy radıl (III); the results (IV); discussion of 
models of the individual planets (V); and a summary (VI). Certain details of the analysis are presented in appendices.

\section{OBSERVATIONS AND INSTRUMENTATION}

The observations were made in ten or more wavelength bands between $35 \mu \mathrm{m}$ and $970 \mu \mathrm{m}$ for each planet. The observations at $\lambda \geq 350 \mu \mathrm{m}$ were made at the 3-m NASA Infrared Telescope Facılıty (IRTF) of the Mauna Kea Observatory; those at $\lambda<350 \mu \mathrm{m}$ were made with the Kulper Alrborne Observatory (KAO). The observations extended over the period 1979 November to 1983 June. All the observations of saturn were made between 1979 November 27 and 1980 May 7 when the ring inclination to earth was $<1.7$.

\section{(a) IRTF}

The IRTF data were obtained in approxımately 330 individual observations during the perıod 1979 November to 1981 March. Flux densities were obtained in $\mathbf{3} 2 \mathrm{x}$ wavelength bands from $350-$ to $1000-\mu \mathrm{m}$ using the University of Chicago Submllilmeter/Millımeter Photometer (Whitcomb, et al. 1980). The signals were obtalned by repetitive beam switching with a beam separation of 300 arc sec.

Figure I shows the transmisgion curves of the filters as measured on a Fourier transform spectrometer. The apertures were $60 \mathrm{~mm}$ for the $1 \mathrm{~mm}$ filter (M2) and $29 \mathrm{~mm}$ for all submillimeter filters. (Plate scale $-2 " / \mathrm{mm})$.

The measurements with the various submillimeter filters were made in a regular sequence degigned to reduce errors due to changes in air mass. The sequence is described in Appendix $\mathrm{C}$. 
(b) RAO

The alrborne observations were made on the 91-cm telescope of the RAO duxing the period 1980 January to 1983 June. Four different helıum cooled photometers were used: photometers GI, Sl, and HI each contalned a single detector and photometer 62 consisted of a close packed hexagonal axray of seven detectors (one central detector surrounded by six). Filter passbands are shown in Figure 2. The filters in photometers GI and $G 2$ were identical and ancluded both bandpass and long-wavelength pass filters. Filters G1-5, G1-6, G2-5 and G2-6 have short wavelength leaks of a few percent or less between $20 \mu \mathrm{m}$ and $50 \mu \mathrm{m}$. These leaks require corrections up to $15 \%$ in flux ratios when comparing objects of significantly different temperatures. For many of the observations, we were able to switch in additional Teflon or Calcium Flourlde blocking filters whlch rendered the leaks completely negliguble. (See footnotes (f) and (g) of Table IV for speciflc notes on filters.)

The two water radiometers on board the KAO are descrubed by Kuhn et al. (1976). For specific notes on the water vapor measurements during the airborne observations, refer to footnote (a) of Table IV. The dependence of the atmospheric transmission function upon the line of sight water yapor was calculated by Stıer (1983 - private communication) based upon the model of Traub and stier (1976).

\section{DATA REDUCTION}

(a) Corrections, Analysis

The signals have been corrected for partial resolution of the 
planetary disks (Append $2 \times$ A), for shadowina of Saturn's disk by the rings (Appendıx B), and for atmospheric transmission and the spectral response of the photometers (Appendixes C, D). The correction for partial resolution dces not include the effect of limb darkenina; the effect of this gimplification 23 estimated in Appendix $A$. Because the ring inclination was less than $1.7^{\circ}$ for all observations, no correction is made for emission from Saturn's rinqs.

For the IRTF data, all signals are corrected to the same values of the line of sight water vapor, w, before takina ratios of unknown to calibration signals $\left(w=I \mathrm{~mm} \mathrm{H}_{2} \mathrm{O}\right.$ for submillimeter measurements, $5 \mathrm{~mm}$ $\mathrm{H}_{2} \mathrm{O}$ for millimeter measurements: see Appendix D). For the KAO data the atmospheric corrections of individual measurements were much lower. The spectra of the unknown and calibration sources were assumed to be similar in qross features for $\lambda \geq 350 \mu \mathrm{m}$, but the source spectra of cold and warm planets (e.g. Neptune and Mars) were not sımilar even in their gross features for $\lambda<100 \mu \mathrm{m}$. It was therefore necessarv to use different analysis procedures for the IRTF and KAO data. see Appendıx D for a description of the IRTF data reduction and Loewenstein et al. (1977a) for the KAO procedure.

\section{(b) Effectzve Wavelength}

The detection efficiency at frequency $\nu$ with ine of siaht water vapor $w$ depends on the atmospheric transmission. T( $\nu, w)$ and on the spectral response of the photometer $A(\nu)$. For a source with spectrum $S(\nu)$, we define a flux welghted mean frequency for the $1^{\text {th }}$ filter to be

$$
\left\langle\nu_{2 w}\right\rangle \equiv \int_{0}^{\infty} \nu S(\nu) A_{L}(\nu) T(\nu, \omega) d \nu / \int_{0}^{\infty} S(\nu) A_{i}(\nu) T(\nu, \omega) d \nu
$$

The wavelengths shown in the tables and figures are those corresponding 
to the mean frequencies so defined (1.e. $\left.\lambda_{2}=c /\langle\nu\rangle_{2}\right)$.

(c) Brightness Ratios

Brightness ratios are calculated from the signal ratios using the planet radil discussed in Section IIIe after corrections for partial resolution of the $d 13 k$ and the inclination of the planet pole.

\section{(d) Calıbration: Mars Model}

Temperatures are derived from the brightness ratıos using Mars as the primary calibration object. The Mars temperatures are based on the model of Neugebauer et al. (1971) as extended by Wriqht (1976) and further extended and tabulated by wright and Odenwald (1980) and Odenwald (1984-private communication). The model predicts a decline in brightness temperature as the wavelength increases. We have assumed $T(\lambda>350 \mu \mathrm{m})=T(\lambda=350 \mu \mathrm{m})$. The errors shown $2 \mathrm{n}$ the tables do not include any estimate of the uncertainty in the model.

We do not attempt to evaluate the accuracy of the Wriqht/Odenwald model. We have, however, compared that model with the more detazled model of simpson et al. (1981). For the times of the observations, the Mars temperatures of the two models were very nearly equal for $\lambda<80$ $\mu \mathrm{m}$. The discrepencies are smaller than the errors we estimate for the measurements. At increasing wavelengths the temperatures of the Sumpson model decrease less rapidly than those of the wriaht/Odenwald model with a discrepency of $-7 \mathrm{~K}$ at $300 \mu \mathrm{m}$. We have assumed the Wright/Odenwald model because it is more easily generated for a quven epoch and because it has been widely used as a standard. We have attempted to quve sufficient data in the accompanyinq tables to allow 
re-calıbration when better reference models are avallable.

(e) Planetary Radız

Published direct observations of planetary radis have been made at different wavelengths zor the different planets and hence correspond to different depths in the atmospheres. The discrepencies are of order one percent in radıus. For consıstency, we use radıl computed for 1 bar pressure levels which should be approxımately the mean radıl for the far IR and SMM emission.

For Jupltex, we use the 100-mbar values $R_{e q}=71541 \pm 4 \mathrm{~km}$ and $R_{\text {pol }}=66896 \pm 4 \mathrm{~km}$ of Lindal et al. (1981). These values were adjusted to the 1-bar level $(z=46 \mathrm{~km})$ with a mean of the IIndal et al. models (e.g. the nominal model given by orton, 1981). For Saturn, we use the $182.2-m b a r$ radius, $R_{e q}=60309.5 \mathrm{~km}$, and ellipticity, $\epsilon=$ 0.096 , of kllore et al. (1980) adjusted to the 1-bar level ( $z=76.6$ km) with a model approximating the preliminary results of Tyler et al. (1982). For Uranus, we use the $8 \times 10^{13} \mathrm{~cm}^{-3}$ (approximately $1 / p$-bar) values $R_{\text {eq }}=26156 \pm 30 \mathrm{~km}$ and $\epsilon=0.024 \pm 0.003$ given by Elliott et al. (1981). The adjustment to the 1-bar level $(z=582 \mathrm{~km})$ is based on the models of Tokunaga et ad. (1983). For Neptune, we use the $4 \times$ $10^{13} \mathrm{~cm}^{-3}$ values $R_{e q}=25225 \pm 30 \mathrm{~km}$ and $\epsilon=0.021 \pm 0.004$ glven by Ell10t (1979), adjusted to the 1-bar level $(z=465 \mathrm{~km})$, again on the basis of the atmospherıc models of Tokunaga et al. (1983). These atmospherlc models for Uranus and Neptune, while constrained by recent infrared data in the $20 \mathrm{um}-$ region, imply altıtude adjustments close to those derived from the equilabrium models of Appleby (1980) or wallace (1980). The largest uncertainty in the radius adjustments for Uranus and Neptune stems from the 


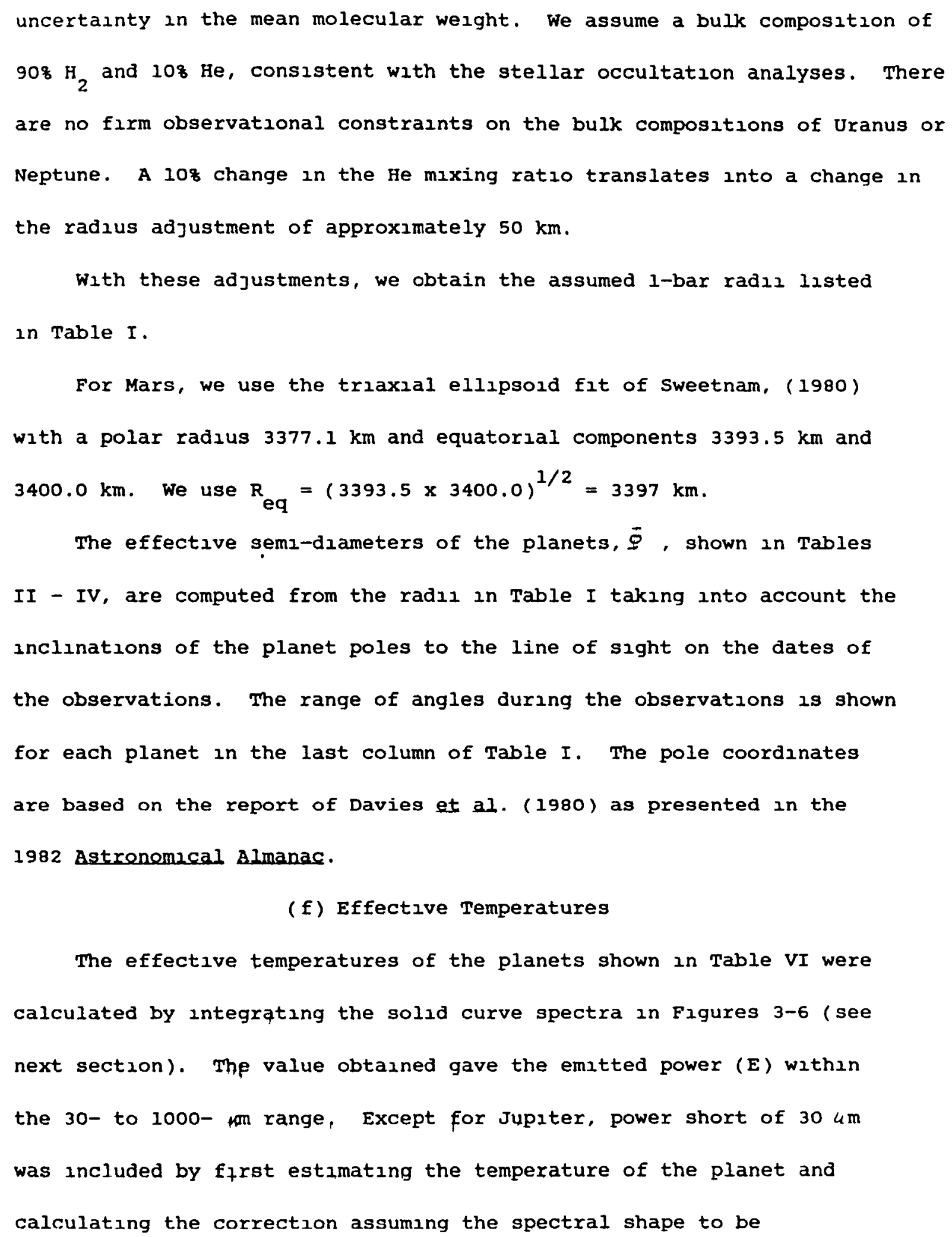

\section{(f) Effective Temperatures}

The effective temperatures of the planets shown in Table vI were calculated by integrating the solid curve spectra in Figures 3-6 (see next section). The value obtained gave the emitted power ( $E$ ) within the 30- to 1000- m range, Except for Jupiter, power short of $30 \mathrm{um}$ was included by first estimating the temperature of the planet and calculating the correction assuming the spectral shape to be 
represented by a blackbody. The temperature is then given by $\mathrm{T}_{\text {eff }}=$ $(\Xi / \sigma)^{1 / 4}$. Juplter's spectrum short of $30 \mathrm{um}$ was taken from Hanel et al. (1979) and combined with the Figure 3 data.

\section{RESULTS}

The Journals of the observations are given in three separate parts: Broadband IRTF observations (Table II), Narrower band IRTF observations (Table III), and KAO observations (Table IV). The brightness temperature measurements are combined and summarized in Table $V$. Since these are not narrow band measurements the power detected depends in part on the shape of the spectrum which is not known a prierl. We therefore use semi-empirical models to estimate the shape and hence to adjust the flux densities. The combined results are plotted in Figures 3 - 6 together with curves representing adjustments of the semı-empirical models fltted to the data. The original models for Jupiter and Saturn are based on those of the Voyager IRIS team (e.g. Hanel et al. 1979; 1982) extrapolated from data taken for $\lambda<50 \mu m$; the models for Uranus and Neptune are those of Tokunaga et 21. (1983). The data were first reduced using these original models (dashed curves). The deviations of the reduced data points from the assumed curve were fitted by a smooth function that was then used to adjust the original model to minimize the deviations. When necessary, this new source curve was then used to re-reduce the original ratios following the procedure described in the appendix of Jaffe et al (1984). This procedure required two fterations for Jupıtex, one for Saturn and Uranus, and none for Neptune. The final curves are shown in the figures (solid curves). The plotted points have been derived assuming the spectral shape of these 
adjusted curves. It should be stressed that these curves are not unique, but represent only plausible spectra containing spectral features predicted by the atmospheric models. The adjusted models give consistent results when each of the glant planets is used in turn to replace Mars as the standard. This is a necessary condition for any valid set of models. The number of integrations used in measuring the airborne points was usually too small to permit estimates of statıstical errors for individual points. Where errors could be estimated, they are shown in Table IV. Since all alrborne measurements are shown in Figures 3-6, the spread can be used to judge the extent of systematic errors. The principal known sources of systematic errors for these points are uncertainties in atmospheric water vapor (alrborne data) and uncertalnty in the Mars model (all data). We emphasize that none of the errors shown in the tables include the uncertainty in the Mars reference temperatures. We assume an absolute accuracy of $\pm 15 \%$ in flux. The averages and statistical errors of the combined data points are tabulated in Table $\mathrm{V}$. The average of the alrborne statıstıcal errors $151.5 \mathrm{~K}$ and represents the average statıstıcal error in any given airborne measurement.

We have plotted the individual alrborne flux densities and the combined groundbased flux densities for each planet in Figures 7 and 8 , normalized to a fixed planetary solid angle. This representation affords a better feeling for the significance of the varıous observational errors.

Recent measurements by oregon/queen Mary College Group (O/QMCG, Orton, et al. 1985) in the range $350 \mathrm{~km}$ to $3.3 \mathrm{~mm}$ are generally in satısfactory agreement with our data, but somewhat lower. The difference is due in part 
to differences in assumed Mars reference temperatures. The principal discrepancy is in the Jupiter data in the region 350- to 500- $\mu \mathrm{m}$, where our points are higher and show a strong peak at $350 \mathrm{um}$ followed by a valley at $\sim 450 \mu \mathrm{m}$. This feature first appeared in measurements with filters CH3 ( 353 m), CH2 $(414 \mu \mathrm{m})$, NO4 $(517 \mu \mathrm{m})$, and CH5 $(664 \mu \mathrm{m})$. Although $1 \mathrm{t}$ appeared in each of three series of measurements on the first night of the observations, we decided to repeat the observations on the following night. Again the feature appeared in Jupiter's spectrum (but not in those of other planets) in each of three series of measurements.

For all of those measurements the lowest measured point was that for the cut-on filter NO4 $(517 \mu \mathrm{m})$. Since the effective wavelength for that filter depended strongly on the relative atmospheric transmission In the 450, 650, and $750, \mu \mathrm{m}$ atmospheric windows, we replaced it in later runs with CH4 $(450, \mu \mathrm{m})$, a relatively narrow band filter with a shorter effective wavelength. The effect was then even more pronounced (two series of measurements on each of two nights).

In view of this sequence of observations and the fact that only Jupiter shows the effect we are confldent that it 13 real. We emphasize, however, that a determination of the exact magnitude of the effect and the exact position of the minimum will require new measurements with narrower band filters. For the filters used in these observations, the results of the iterative procedure used to derive the flux densities from the signals depend strongly on the spectral response, including atmospherıc effects, in regions where the brightness temperature of the source changes rapidly with wavelength. 
The strong dependence on spectral response may explazn or contribute to the discrepancy between our results for Juplter and those of the O/QMCG which do not show the same structure near $400, \mathrm{~km}$. We emphaszze however, that the results are generally in good agreement. Evidently, this portion of Jupiter's spectrum should be re-examined with narrower passbands. Integrating the curves $2 n$ Figures 7 and 8 and correcting for unmeasured flux shortward of $35, \mathrm{~m}$, one derives the effective temperatures given in Table VI. E/A 23 the ratıo of emitted to absorbed radiation.

\section{v. DIsCUSSION}

The 30- to 1000- um spectral range covered by our data contalns approximately $50 \%$ of the total flux from Juplter, 65\% from Saturn, 92\% from Uranus, and $92 \%$ from Neptune. We are therefore able -- especially for Uranus and Neptune -- to reduce considerably the uncertainties in determining the effective temperatures. The implications of these temperatures for internal energy sources are discussed later in this $\operatorname{sectzon}(\xi \vee B)$

First, however, we discuss the predictions of a number of theoretıcal atmospheric models, the details of which are presented in Appendix E. The model spectra are useful as first-order approxımations in the reduction of signal ratios to brightness temperatures, as in section IV, and for extrapolating to wavelengths not actually observed (e.g., when estimating effective temperatures). Such extrapolations (specifically, from the 30- to 50- $\mu \mathrm{m}$ region in which voyager data on Jupiter and saturn may be used as alternatives to the absolute 
calibration based on Mariner measurements of Mars) can also provide a consistency check on our absolute calibration system. Finally, comparing predicted spectra with observed fluxes allows us to test the plausibility of certaın assumptions about temperature profiles, mixing ratios, and cloud structure.

\section{A. Comparisons with Atmospheric Models}

The Voyager IRIS experiment has obtained many absolutelycalibrated spectra of Jupiter, including some observations of the whole disk, out to a wavelength of $50 \mathrm{um}$ (Hanel et al. 1979). The theoretical curves displayed in Figures 9-11 are all consistent with the Voyager results (Orton et al. 1982b). The agreement of the Voyager and KAO fluxes provides an independent check on the absolute calıbration in the 30to 50- um region. Figure 9 includes the spectrum of a model atmosphere wathout $\mathrm{NH}_{3}$ ice clouds and one with $\mathrm{NH}_{3}$ clouds having a characteristic particle scale height $\left(H_{p}\right)$ equal to 0.15 times the scale height of the gas $\mathrm{H}_{\mathrm{g}}$ ). Figures 10 and 11 show spectra resulting from similar clouds with particle scale herghts equal to 0.50 and 0.05 times the gaseous scale helght, respectively. The models are extensions of those presented by orton et al. (1982b). Although they predict that the presence of $\mathrm{NH}_{3} 1 \mathrm{ce}$ partıcles will decrease the brightness temperature between $300 \mathrm{um}$ and 500 $4 \mathrm{~m}$, none matches the shape of the observed spectrum in detall. Hence, although the data suggest the presence of some source of gaseous opacity in Jupiter's atmosphere which is not prominent in the atmospheres of the other glant planets, determınıng its nature may require additıonal observatıons (In particular, measurements at higher spectral resolution which permit 
more accurate correction for telluric absorption) and refinements in the theoretical models. (See discussion in $\zeta I V$. )

Figure 12 shows spectra of models for Saturn with a $\mathrm{PH}_{3} \mathrm{~m} \mathrm{x}$ ing ratio of $1.5 \times 10^{-6}$ in the deep atmosphere, following the results of earlier investigations (see Appendix E). Models with larger mixing ratios have been included to show the influence of $\mathrm{PH}_{3}$ lines in this region of the spectrum. The measurements at $204.3,221.1$, and 328.9 im all appear to lie below the model spectra and could be interpreted as indicating that larger mixing ratios are required or that there is an unmodeled absorber. Since the model spectra in Fig. 12 provide satisfactory fits to the data throughout most of the far infrared, we conclude that the global average of the optical depths of the clouds cannot be as high as the values suggested by orton (1983) for clouds near the equator and near $15^{\circ} \mathrm{s}$. latitude. The average depth may be reduced by relatıvely bright "clear" regions in the northern hemısphere (Pirraglia et al. 1981; Gautier et al. 1983).

Models based on the Uranian temperature profile of Tokunaga et al. (1983, shown here in F2g. 13) give a reasonable fit to our data. The differences in the temperature near and below the 1-bar pressure level are a direct consequence of varıous assumptions about the mixing ratio of $\mathrm{CH}_{4}$ in the deep atmosphere (see Appendix E). The submillimeter fluxes are sensitive to the $\mathrm{CH}_{3}$ mixing ratıo because of the pronounced effects of the latent heat of condensation on the adiabat for large abundances .

The temperature structure assumed for Neptune (F1g. 15) resulted from perturbing the models which Tokunaga et al. (1983) based on the 
results of Appleby (1980), in order to achieve the best fit to our data. The required temperatures at the 300- to 500-um bar level are one to two degrees coc ser than assumed by Tokunaga et al. Among the model spectra shown in Figure 14 and Figure 16, the ones with the lowest $\mathrm{CH}_{4}$ abundance provide the best fit to the observations across the entire spectral range (although this statement 19 based almost exclusively on the single data posnt at $960 \mathrm{~km}$ in the case of Neptune). Data from the O/QMCG will provide additional constraints near $1 \mathrm{~mm}$. Our submillimeter data suggest a $[\mathrm{C}] / \mathrm{H}]$ elemental abundance ratıo near or below Jovian or solar values (Orton, et al. 1985). The models provide satisfactory fits to the $17.8 \mu \mathrm{m}$ and $19.6 \mu \mathrm{m}$ data of Tokunaga et al. (1983). All of the model temperatures are cooler than those given by the observations of orton et al. (1983) at 10.3, 11.6, and $12.5 \mathrm{um}$, which is consistent with their interpretation that part of the flux in this spectral region is reflected sunlight. The greatest difficulty associated with the Uranus and Neptune models 19 the divergence between the high brightness temperatures which they predict at $3 \mathrm{~mm}$ (for low $\mathrm{CH}_{4}$ abundances) and the much lower observed temperatures (e.g., Ulıch 1981) whlch would appear to be better matched by the $28 \mathrm{CH}_{4}$ model. This 15, of course, the spectral region for which the Martian brightness temperatures upon which the absolute calıbration of the submllilmeter photometry is based are most uncertain. However, the 960 um fluxes for Jupiter and saturn are not excessively hıgh.

\section{B. Effective Temperatures}

The thermal energy fluxes of Jupiter and Saturn due to internal 
sources of heat are equal to 1.8 and 1.7 times the solar input, lower than previous values. The decrease 19 due to the use of more recent estimates of the Bond albedos (see Table VI). For Jupıter, the value 19 consistent with an interpretation in which all of the excess power is supplied by gravitational contraction and heat stored from the original contraction of the planet fxom the solar nebula (Graboske et al. 1975; Bodenhelmer et 2.1. 1980). Saturn, however, requires an additional source of energy which can most plauglbly be provided by differentiation of helium within the interior (e.g. Stevenson 1980 ). The effective temperature which we derıve for Uranus is similar to the previous estimates by Fazıo et al. (1976), Loewensteln et al. (1977b), and stier et al. (1978). There 1 s no indication of a change over thıs period of time. Lockwood et al. (1983) have derlved Bond albedos of $0.342 \pm 0.032$ for the 1962 epoch and $0.393 \pm 0.037$ for the 1981 epoch. From these values, one would predict equilibrium temperatures of $57.0 \pm 0.8 \mathrm{~K}$ and $55.8 \pm 1.0 \mathrm{~K}$, respectıvely. Recent prelımınary work has been done to remeasure the geometric albedo (Neff et al. 1984 ). This work extends measurements of the phase function of the planetary dısk to high angles via the Voyager spacecraft Imaging subsystem experiment (Wenkert et al. 1984), and combines these with atmospheric cloud models which provide reasonable extrapolations to high phase angles in the full spectral range of relevance (Pollack et al. 1984 ). The derlued Bond albedo 19 in the range 0.31 and 0.42 , $1 \mathrm{mply}$ ing an equilibrium temperature of $56.4 \pm 1.2 \mathrm{~K}$. There 19 sufficient overlap in the uncertainties of absorbed and emitted energy to support the absence of an Internal heat source or one as large as 408 of the absorbed solar 
energy.

Our new effective temperature for Neptune $(60.3 \pm 2.0 \mathrm{~K})$ is larger than the earlier values of Loewenstein et al. (1977b; $55.5 \pm 2.3 \mathrm{~K}$ ) and

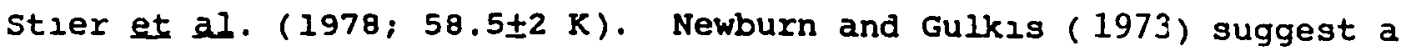
Bond albedo for Neptune which is approximately the same as for uranus, based on the similarity of their spectra. Murphy and Trafton (1974) recommend a similar value. Albedos of 0.33 or $0.341 \mathrm{mply}$ an equilibrium temperature of about $45 \mathrm{~K}$. As in the case of Uranus, more recent prelıminary work has been done on the geometric albedo (Neff et al. 1984), but only limited observations have been made of the phase function (Wenkert et al. 1984). As of this writing atmospheric cloud models (Pollack et al. 1984) are still very primatıve. Assuming the same phase integral as for Uranus, we estimate the Bond albedo of Neptune to be about 0.29 , Implying an effective temperature of $46.4 \mathrm{~K}$. The uncertainty is probably about the same as for the temperature of Uranus. Our data thus imply an internal power source for Neptune approximately 2.8 times larger than the absorbed solar flux. Although this value is significantly larger than the limit for uranus, Hubbard and MacFarlane (1980) have pointed out that 2 t 13 still less than expected on the basis of homogeneous cooling from an initial hot state, and they postulate that the avallable fossil heat was reduced during its evolutionary history by upward redistribution of heavier materials.

\section{SUMMARY}

We have presented new photometric data on the grant planets covering the range $30-$ to $1000-, \mu \mathrm{m}$. The data permit a more accurate 
determinations of effective temperatures than earlier studies with broader filters, more limited data sets, and less complete spectral coverage. Our results are generally consistent with previous work, and major conclusions regarding internal heat sources are unchanged.

It is relatively easy to fit a range of reasonable atmospheric models to our data in the $30-$ to $100-\mu \mathrm{m}$ wavelength range. Fluxes at longer wavelengths are sensitive to a number of parameters, such as the presence of $\mathrm{NH}_{3}$ ice particles in Jupiter's atmosphere and the $\mathrm{CH}_{4}$ mixing ratio in Uranus and Neptune, but to discriminate between models, from moderate-bandwidth photometry would require accurate absolute calibration. Since no direct absolute calibration is avallable in the 100- to 1000- um spectral range, any conclusıons about atmospheric structure from current submilimeter data should be regarded as tentative. With that caveat, we can make the following observations: (1) Our data indicate the presence in Jupiter's spectrum of excess emission (compared to theoretical models) at 300-400, $\mathrm{km}$, followed by a pronounced dip at $-500 \mu \mathrm{m}$. Additıonal measurements with higher spectral resolution would be desireable. The observations of the O/QMCG will provide additional data in the SMM region and will extend to longer wavelengths.

(2) There 19 slightly less flux observed from saturn at $-200 \mu \mathrm{m}$ than predicted by our atmospheric models, suggesting the possible presence of an unmodelled absorber.

(3) The submillimeter fluxes from Uranus and Neptune seem most consistent with low mixing ratios (<Iz) of $\mathrm{CH}_{4}$ in their deep 
atmospheres.

\section{ACKNOWLEDGEMENTS}

We thank the staffs of the IRTF and KAO for their assistance during the observations. This work was supported by NASA grants NSG2057, NAG-W-4, and NGR 14-001-227. RHH and RFL wish to thank J. Simpson and M. Stıer for additıonal Mars modelıng; Harvey Moseley and the Oregon/Queen Mary College Group for allowing us to use unpublished data; and the staff and crew of the KAO for their usual superb help. We are grateful to Ira Nolt for comments on a draft of the manuscript. GSo acknowledges support from the Gallleo Project and from the Planetary Atmospheres Program of the NASA Office of space sciences and Applications for work carried out under NASA contract NAS 7-100 at the Jet Propulsion Laboratory, Callfornia Institute of Technology. We thank J. Hansen, N. Habra and D. Soll at the NASA Goddard Institute for Space studies for computing support; G. Birnbaum and C. Chapodos for laboratory results in advance of publication; and J. Appleby, $K$. Baines, J. Bergstralh, S. Gulkı, M. Kleın and T. Thompson for useful advice relevant to this work. 


\section{APPENDIX A}

Partial Resolution of the Planetary Disk

In some cases, especially the observations of Jupiter, the anqular radius of the planet is appreciable in comparison with the beam radius. It 13 therefore necessary to correct the observed slanals for partial resolution of the disk, 1.e. for a decrease in detection efflciency with increasing displacement from the optıc axıs. The normalized scans of Mars give the efficiencies, $E(\varnothing)$, as a function of the drsplacement, $\phi$. To good approximation these scans can be fitted by gaussians. For a planet of angular radius $\Phi$ in which the briahtness 19 a function $b(\alpha)$ of the emission anqle $\alpha=\operatorname{arc} \sin (\Phi / \Phi)$, the disk correction $2 s$

$$
D(\Phi)=\int_{0}^{\Phi} \quad b(\alpha) \pi \phi d \phi / \int_{0}^{\Phi} E(\phi) b(\alpha) \pi \phi d \phi . \quad \text { (A1). }
$$

i.e., if $\mathbf{S}=$ observed signal, then $D(\bar{\Phi}) S=$ sıanal which would be observed for a planet of the same lumsnosity and the same $b(\alpha)$, but with $\Phi \rightarrow 0$.

We have used the assumption $b(\alpha)=$ constant to obtaln the corrections shown in Tables II and VI. As an indrcation of the sensitivity of $D(\Phi)$ to $b(\alpha)$ we have used the $45 \mu \mathrm{m}$ (Pioneer 10 and 11 ) values of $b(\alpha)$ determined for Jupiter by Inqersoll et al (1976). We have made fits of smooth curves to their measured values averaged over five zones of latitude. The difference between the corrections for $b(\alpha)=$ constant and for $b(\alpha)$ based on Inqersoll et al (1976) is neqligible in comparıson with our estımate of the error (10\%) in $D(\Phi)-1$ due to uncertainties in $E(\Phi)$. 


\section{APPENDIX B - EFFECT OF SATURNS RINGS}

Voyager 2 measured the temperatures of the $A$ and $C$ rings of Saturn to be $69 \mathrm{~K}$ and $85 \mathrm{~K}$ respectively (Hanel et al, 1982). At the encounter, the ring inclination to the sun was $8^{\circ}$. At the time of our observations the ring inclination angle to the sun was $< \pm 1^{\circ}$. Because of the low inclination we assume that the ring temperature would be significantly less than the temperatures measured by voyager. In this case, the dominant effect of the rings would be to block the emission from the disk. Since the ring inclination to earth was always less than $1.7^{\circ}$ during our observations, the greategt reduction in the effective disk area would be 1.5\%. The correction is much lower for $\lambda \geq 3004 \mathrm{~m}$.

\section{APPENDIX C - SEQUENCE OF GROUND-BASED MEASUREMENTS}

The Individual observations used in the IRTF investigations followed a regular pattern. Consıder, for example, a serıes of observations of Mars, Jupıter and Saturn using the submillımeter filters $\mathrm{CH} 2$ (broadband), and $\mathrm{CH} 3, \mathrm{CH} 4, \mathrm{CH} 5$ (narrower band). We use M2, J3, etc. to denote observations of Mars with filter CH2, Juplter with fliter $\mathrm{CH}_{3}$, etc. and $\mathbf{s}(\mathrm{M} 2), \mathrm{S}(\mathrm{M} 3)$ etc. to denote the corresponding signals.

A single series would proceed in the order M2, M3, M4, M5, M2, J2, J3, J4, J5, J2, S2, S3, S4, s5, s2, and the entire serles would be repeated at least once and usually twice. Note that fllter $\mathrm{CH} 2$ was used before and after the other filters on each planet. It usually took less than 10 minutes to complete the five successive counts on a single planet. The corresponding change in alr mass was usually< 005 . 
Hence corrections for changes in air mass within the set of five counts were almost negligible. In computing ratios of counts such as $S(M 3) / S(M 2)$ for one series we sumply interpolated linearly by alr mass between the $S(M 2)$ values at the beginning and the end of the serzes to find a value for the air mass corresponding to $M 3$.

The time between the first and second series for a given planet was approxımately 45 minutes. The corresponding change in air mass, typically 0.15, was usually enough to cause a small but measureable change in a signal ratio such as $S(M 3) / S(M 2)$. Insofar as possible, the observatıons were tımed to give equal alr masses for each of the planets when averaged over all observations for one night.

\section{APPENDIX D - ANALYSIS OF IRTF DATA}

\section{(1) Broadband Data}

The counts obtalned with the broadband fliters CH2 and MP2 are insensitive to fine structure in the source spectra, they have high statistical accuxacy, and they have been repeated often enough to provide well-sampled signal vs, alr mass curves. We use these counts to derıve brıghtness ratıos for the varıous planets, and to provide reference points in deriving the shapes of the individual spectra $(\operatorname{section} 2)$.

The steps in the analysis of the broadband data are as follows:

(1) Plot the signals vs. alr mass for each planet for each night. Discard all data on nights when the curves indicate a change in water vapor.

(11) To those plots, fit the water vapor curves to estimate the 
zenith water vapor.

(111) Adjust all the data for a given night to a common line-ofsight water vapor.

(iv) Combine the adjusted values welghting individual counts according to their nolse values, using the nominal errors or the mean error, whichever 13 larger.

(v) Make a Ch1-Squared test of the $\mathrm{N}$ adjusted values and increase the error of the combined result by $\left(\chi^{2} / N\right)^{1 / 2}$ if the reduced $\operatorname{ch} I$ squared $1 s>1$.

(v1) Calculate the ratios of the averages $\langle S(J 2)\rangle /\langle S(M 2)\rangle$ etc. where the counts in the denominators are for the reference planet (Mars, or, where necessary, an intermediate standard).

(vii) Multiply the ratios by the disk correction factors shown in Tables II and IV and by the ratios of planetary solid angles to obtain global surface brightness ratıos $B(J 2) / B(M 2)$ etc. For the range of water vapor of these measurements, the brightness ratiog for these filters on different nights are in satisfactory agreement and show no dependence on zenith water vapor: the expected result for the broadband data, whatever the fine structure, if overall the planets have roughly Raylelgh-Jeang spectra within tine passbands of the filters (as assumed in preparing the water vapor curves).

(viil) Assume a brightness temperature for the reference planet for the date of the observation and calculate a brightness temperature for the "unknown" planet.

(1x) Combine the brightness temperatures for the various nights 
with weighting and chi-squared tests as in steps ( IV) and

(v). We assume no change in glant planet temperatures durıng the period of the observations. No change is indicated by the results.

\section{(2) Narrower Band Data}

In principle, the procedure we have described for the broadband data could be used also to find the signal ratios $S(J 3) / S(M 3)$ etc. and hence the brightness temperatures for the narrower bands. However, the errors in determining the relative brightnesses in the various passbands for a single planet are reduced by the following procedure:

(2) Calculate $[S(M 3) / S(M 2)]_{w},[S(J 4) / S(J 2)]_{w}$, etc., where $w=$ line of sight water vapor for a particular measurement of $S(M 3), S(J 4)$, etc. and $S(M 2)_{w}, S(J 2)_{w}$, etc. are the values of the broadband signals interpolated to the same values of w. These ratıos are not independent of w; e.g. s3/s2 decreases and 55/S2 increases with increasing w. Typically, the change from one serzes to the next $193-10 \%$.

(11) Adjust the ratios for successive series to a common value, w. using empırıcally determıned correctıons (Iınear in w) based on the data for all runs. The ratzos thus determined agree within statistics. For the submililmeter data (filters CH2, CH3, N4, CH4, and CH5) we choose $w_{0}=1 \mathrm{~mm}$. The range of values $1 \mathrm{~s} 0.3 \leq w \leq 1.5 \mathrm{~mm}$. For the millimeter data (filters MP2 and MP4) we choose $w_{0}=5 \mathrm{~mm}$. The range of values $1 \mathrm{~s} 3.4 \leq w \leq 6.4 \mathrm{~mm}$. 


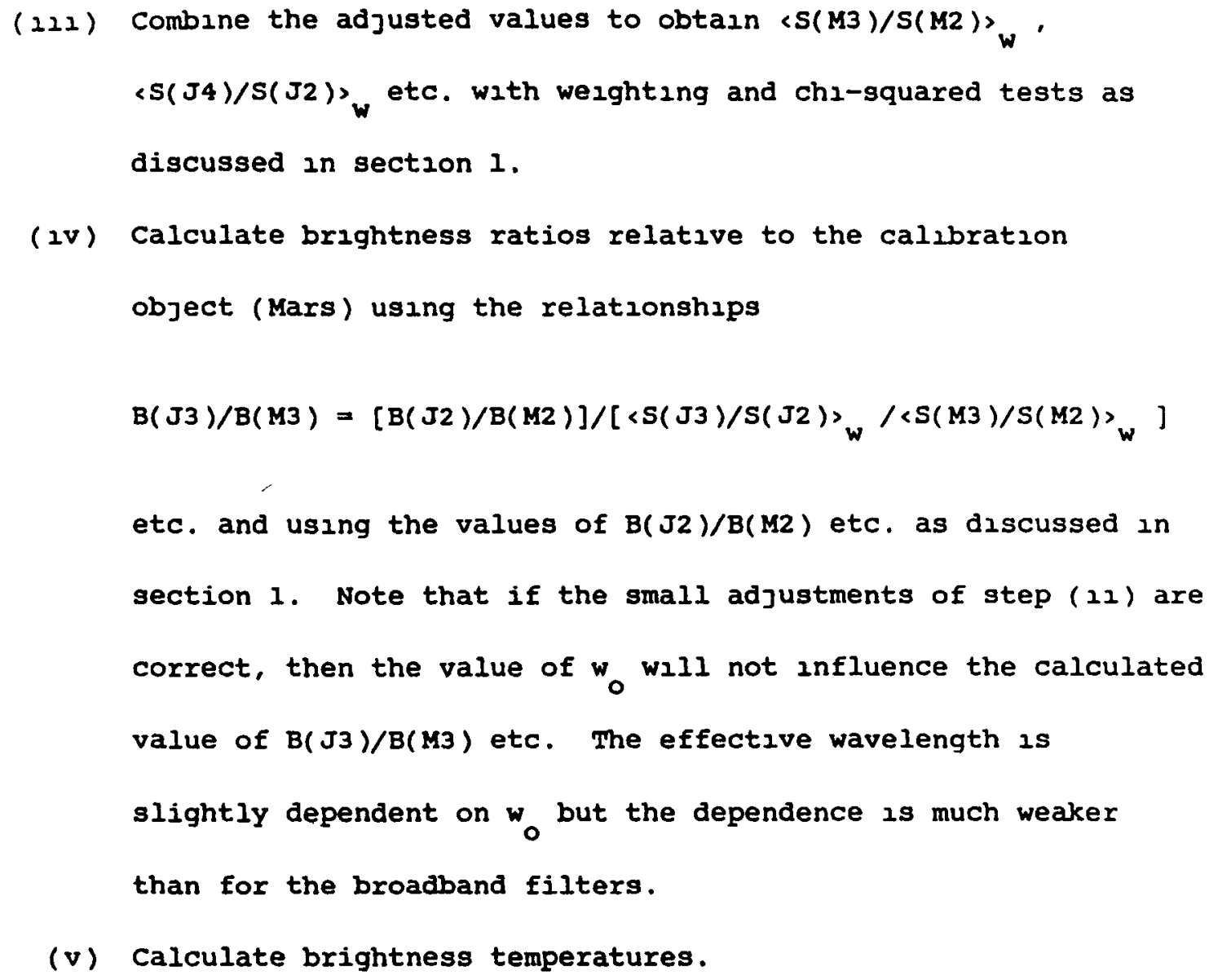




\section{Details of Atmospheric Models}

Synthetic spectra of Jupiter and Saturn were computed from physical models with $10 \mathrm{~cm}^{-1}$ wide ("flat") elements centered at 99 through $499 \mathrm{~cm}^{-1}$ and $5 \mathrm{~cm}^{-1}$ wide elements centered at 34 through $99 \mathrm{~cm}^{-1}$ for the airborne observations, and $2.5 \mathrm{~cm}^{-1}$ wide elements at 9.0 through $34.0 \mathrm{~cm}^{-1}$ for the ground-based observations. Th1s approach allowed absorption features such as the manifolds of $\mathrm{NH}_{3}$ rotationinversion lines to be resolved.

The opacity of the Jovian atmosphere is dominated by $\mathrm{H}_{2}$ and $\mathrm{NH}_{3}$ in the $40 \mu \mathrm{m}-1 \mathrm{~mm}$ region. The $\mathrm{B}_{2}$ collision-induced dipole absorption was calculated using recent models derıved for a variety of collıding species: $\mathrm{H}_{2}-\mathrm{CH}_{4}$ according to Dore et al. (1983), $\mathrm{H}_{2}-\mathrm{He}$ according to Cohen et al. (1985). Absorption by $\mathrm{NH}_{3}$ was calculated using direct Integration of inversion and rotation-inversion lines whose spectroscoplc parameters are sumnarized by Husson et al. (1982), based on Husson et al. (1981). Additzonal gaseous absorption by $\mathrm{PH}_{3}$ and $\mathrm{CO}$ was modelled using line parameters given by Hussonet al. (1982). The radiatıve transfer calculations were performed using the matrix operator algorıthm of Grant and Hunt (1969) in a multıple-layer approximation which used twenty homogeneous layers per decade of pressure change to simulate the gradual change of atmospherıc properties with altitude. Direct integration of line absorption was performed using the method of scott (1974) as modified by orton (1981). The temperature structure of Jupiter used in the calculations was adopted from the neutral atmosphere inversion of the voyager Radio 
Subsystem (RSS) occultation experiments (LIndal et al. 1981), assuming respective molar fractions of 898 and 118 for $H_{2}$ and He (Gautier et al. 1981). Ammonia was assumed to have a molar mixzng ratio of $2.2 \times 10^{-4}$ in the deep atmosphere (IIndal et al. 1981) with depletion of higher levels owlng to saturation equilibrium and photochemical destruction as modelled by orton et al. (1982a). The vertical distribution of $\mathrm{PH}_{3}$ was represented by a maxımum mixıng ratıo of $6 \times 10^{-7}$ with a gradual depletion with altitude above the 1 bar level, following the profile derıved by Kunde et al. (1982) from Voyager IRIs spectra. A constant co mixing ratio of $2.5 \times 10^{-9}$ was assumed, an average of the approximate results of Beer (1975) and Larson et al. (1978). We note that the Influence of $\mathrm{PH}_{3}$ and $\mathrm{co}$ lines on the spectrum in $10.0 \mathrm{~cm}^{-1}$ through $2.5 \mathrm{~cm}^{-1}$ resolution elements appeared to be small.

The temperature structure of saturn used in the calculations was derived from the results of the planet-wide averaged temperature structure determined from the Voyager IRIS data given by Hanel et al. (1983), with temperatures deeper than 350 mbars derived from the preliminary neutral atmosphere inversion of the Voyager IRIS occultation experiment (Tyler et al. 1982) after adjugtment of the bulk composition to $938 \mathrm{H}_{2}$ and 78 He (Gautzer et al. 1983). Ammonza was assumed to have a molar mixing ratıo of $2 \times 10^{-4}$ in the deep atmosphere. An alternative value of $5 \times 10^{-4}$ was tested, following models limits given by Klein et al (1978), and was found to affect our spectra negligibly. Depletion of $\mathrm{NH}_{3}$ at high levels followed saturation equilibrium. A simple model for the vertical distribution 
of $\mathrm{PH}_{3}$ was used: a constant mixing ratio of $1.5 \times 10^{-6}$, roughly consistent with the results of Tokunaga et al. (1980) and Courtin et al. (1981), with a cutoff near the base of the stratosphere. We discovered that the presence or absence of stratospheric $\mathrm{PH}_{3}$ was not significant for our calculations. For consıstency with Juplter, we assumed a constant co mixing ratio of $2.5 \times 10^{-9}$, although 1 ts influence on our calculations of the saturnian spectrum was extremely small, (as was the case for Jupiter.)

We also tested various physical models for $\mathrm{NH}_{3}$ ice clouds in the Jovian atmosphere following the general scheme used by orton et al. (1982b). The particles are characterızed by a mode radius which is left a free parameter, a $10 \%$ variance in the particle size distribution, and a scatterıng phase function taken from fitting the $\mathrm{NH}_{3}$ particle phase function observed in the laboratory wath visuble light (Holmes, 1981; Holmes et al., 1980) using the Pollack and Cuzzl (1980) semı-empirical algorıthm for irregularly-shaped partıcles. No cloud partıcles were assumed hıgher than the 100-mbar temperature manımum or deeper than the 630-mbar saturation level. The vertical distribution was parameterized by particle scale helght to gas scale height ratios, $\mathrm{H}_{\mathrm{P}} / \mathrm{H}_{\mathrm{g}^{\prime}}$ of $0.50,0.15$ and 0.05 . Indices of refraction for $\mathrm{NH}_{3}$ 2ce were taken from Martonchlk et al. (1983) which are based primarily on the absorption measurements of sill et al. (1980). For very low frequencies absorption was extrapolated exponentially downward with decreasing frequency, consistent with the lowest avallable frequency measurements of 5111 et al. This treatment 2 gnores possible phonon absorptions, such as occur in water ice (e.g. Mishima et al.. 
1983), owing to the absence of relevant laboratory data. Other restrictions on the particle size and vertical scale height determined by orton et 2l. (1982r) were also observed. As discussed in the main text, physical models for clouds in the saturnian atmosphere were not invoked.

The 35- to 100- $\mu \mathrm{m}$ spectra of Uranus and Neptune are expected to be dominated by the collision-induced absorption of $\mathrm{H}_{2}$, and the comparison with model spectra tend to support this view. At this time, there is no evidence to suggegt that non-contınuous features should be present in the spectrum. For Uranus (and Neptune) the low temperatures eliminate $\mathrm{NH}_{3}$ at detectable levels, unless present in abundances exceeding saturation equilibrium by many orders of magnitude. Phosphene should also be depleted by saturation equilibrium, although not as much as ammonia. Although carbon monoxide may not be depleted by a similar process, its influence on the measurements should be very small if 2 ts muxing ratios in Uranus and Neptune are simllar to Jupiter. We therefore assumed that the spectrum could be described well by the continuum due to $\mathrm{H}_{2}$. Thus, direct comparısons between the computed spectrum and the brightness temperatures given in Table II at various wavelengths are physically meaningful.

For the temperature structures for Uranus and Neptune, we followed a procedure adopted by orton et al. (1983) which examines existing models by Tokunaga et al. (1982). Their temperature structures are partially based on radiative-convective equilibrıum models of Appleby (1980) and are constrained to match 17.8 and $19.6 \mu \mathrm{m}$ observations. 
The temperature structures characterizing the 2 models were perturbed in a way which optimized the fit to our data between 40 and $100 \mu \mathrm{m}$. As a baseline composition, we assumed a mixing ratio of 908 for $\mathrm{H}_{2}$, close to those for Jupiter and Saturn. The remainder was assumed to be composed of He and $\mathrm{CH}_{4} \cdot \mathrm{CH}_{4}$ influences the thermal spectrum in two ways. First, $\mathrm{CH}_{4}$ collisions with $\mathrm{H}_{2}$ change the $\mathrm{H}_{2}$ collisioninduced dipole absorption spectrum for that produced by $\mathrm{H}_{2}$ or He collisions. Second, $\mathrm{CH}_{4}$ condensation in the upper troposphere lowers the dry adiabatic lapse rate via latent heat (e.g. Eq. 3 of Wallace. 1980). The extent of this wet adlabat 2 s controlled by the amount of $\mathrm{CH}_{4}$ in the deep, uncondensed atmosphere. Three values for this $\mathrm{mix}$.ng ratio were tested: $0.28,28$ and 48 . The first 13 close to the Jovian value (Gautıer et al. 1982), the second is an arbitrary "Intermediate" value, and the last is a value recommended by Baines (1983). Values as high as 108 have been suggested for Uranus (Danlelson, 1977), but these were Judged by orton st al. (1983) to be unlikely.

The approxımate agreement between the shape of the model spectra of Uranus and Neptune and the data argues that the compositional assumptions Implicit in the model are not unreasonable. The data in the 10- to $12-\mu \mathrm{m}$ regions could be fitted better by thermal emission alone if the molar fraction of He were increased substantlally (e.g. to 50\%), but this is considered unlikely. Increasing the He mixing ratıo substantially from the values used in the models tends to supress the $\mathrm{H}_{2}$ rotational features at 16 and $27 \mu \mathrm{m}$, flatten the brightness temperature spectrum between 40 and $100 \mu \mathrm{m}$, and Increase the rise in the brightness temperature toward longer wavelengths. The slow 
variation of temperature with altitude, combined with the limited data set make it impossible to determine a trustworthy value for the He mixing ratio at this time, as in Gautıer et al. (1981) for the Voyagex IRIS spectra of Juplter. On the other hand, it 13 clear that the immediate effect of replacing a substantial portion of the equilibrium $\mathrm{H}_{2}$ by normal $\mathrm{H}_{2}$ in the model 23 to increase the absorption in the 100to $200-\mu m$ range relatıve to shorter wavelengths, making it much more difficult to fit both spectral regions simultaneously. Some caution 1 s warranted at this point. First, we are extending the models for $\mathrm{H}_{2}$ collision-znduced absorption well below the lowest temperature at which measurements have been made (cf. Dore et al. 1983), and the uncertainty involved in such an extrapolation is difficult to estimate. Other changes in the shape of the general continuum would take place under the influence of clouds in the atmosphere if the particle size were sufficlently large, as may occur In the atmosphere of Jupiter with $\mathrm{NH}_{3}$ lce particles (orton et al. 1982). Finally, changes in the He mixing ratio or the addition of

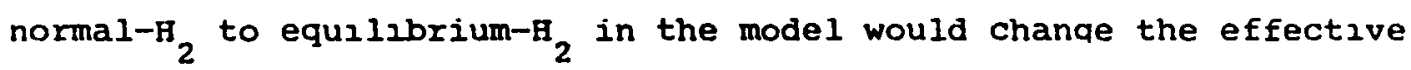
specific heat of the atmosphere and influence the temperature lapse rate in the convectlve (adlabatic) part of the atmosphere for pressures greater than about 400 mbar. Such changes would influence the brightness temperature increase for wavelengths of about $200 \mathrm{um}$ and above and complicate the simple association we have presented between the brightness temperatures in the submillimeter and the mixind ratio of $\mathrm{CH}_{4}$ in the deep atmosphere. 
Appleby, J.F. (1980). Atmospheric Structures of the Giant Planets from RadiativeConvective Equilıbrium Models, Ph.D Thesis,State Unıv. of New York, Stony Brook. Aumann, H. H., C. M. Gilesple, and F. J. Low (1969). The internal powers and effective temperatures of Jupıter and saturn. Astrophys. $I$. 157, L69-L72.

Baines, K. H. (1983). Interpretation of the $6818.9 \AA$ methane feature observed on Jupiter, Saturn and Uranus. Icarus. In press.

Beer, R. (1975). Detection of carbon monoxide in Jupiter. Astrophys. IL 200, LI.7-LI9.

Bodenhelmer, P.. A. S. Grossman, W. M. DeCanpli, G. Marcy, and J. B. pollack (1980). Calculations of the evolution of the grant planets. Icarus 41 293-308.

Cohen, E. R., I. Frommhold, and G. Birnbaum (1985). Analysis of the far infrared $\mathrm{H}_{2}$-He spectrum. Astrophys. $J$ In press.

Courtın, R., D. Gautıer, A. Marten and W. Maguıre (1981). The acetylene and ethane abundances and the phosphine distribution in Saturn's atmosphere from the voyager 1 - IRIS experıment. Buld. Amer, Ästron. Soc. 13, 722.

Danielson, R. E. (1977). The structure of the atmosphere of Uranus. Icarus $30,462-478$.

Davies, M. E., V. K. Abalakın, C. A. Cross, R. L. Duncombe, H. Masursky, B. Morando, T. C. Owen, P. K. Seldelmann, A. T. Sinclalr, G. A.WIlkıng, and Y. C. TJuflın (1980). Report of the IAU Working Group on cartographıc coordinates and rotational elements of the planets and satellites. Celestzal Mechanics $22205-230$. 
Dore, P., I. Nencinl, and G. Birnbaum (1983). Far infrared absorption in normal $\mathrm{B}_{2}$ from $77 \mathrm{~K}$ to $298 \mathrm{~K}$. I. Quant. Spectrosc. Radiat. Transfer 30 245-254. Elliot, J. I. (1979). Stellar occultation studzes of the solar system. Ann Rev. Astron. Astrophys. 17. $445-475$.

Ellıot, J. L., E. Dunham, D. J. Mink, and J. Churms (1980). The radius and ellipticity of Uranus from its occultation of SAO 158687. Astrophys, IL 236, 1026-1030.

Ellzot, J. I., R. G. French, J. A. Frogel, J. H. Elıas, D. J. Mink, and W. Liller (1981). Orbits of nine Uranian rings. Astron. J. $86,444-455$.

Erıckson, E. F., D. Goorvich, J. P. Sumpson, and D. W. Strecker (1978). Far infrared brightness temperatures of Jupıter and Saturn. Icarug $35,61-73$.

Fazıo, G. G., W. A. Traub, E. L. Wright, F. J. Low, and L. M. Trafton (1976). The effectzve temperature of Uranus. Astrophys. I. 209. $633-537$.

Gautıer, D., B. Conrath, M. Flasar, R. Hanel, V. Kunde, A, Chedın, and is. Scott (1981). The helium abundance of Juplter from Voyager. J. Geophys, Res, 86, 8713-8720.

Gautier, D., B. Bezard, A. Marten, J.-P. Baluteau, A. Chedın, V. Kunde, and $R$. Hanel (1982). The C/H ratio in Juplter from the voyager Infrared 2nvestıgation. Astrophys. J. 257, 901-912.

Gautier. D.. B.A. Conrath. R.A. Hane1, and .T.S. Hornatein (1984). The he1ium abundance of Saturn from Vovager measurementa. Aatrodhvs. J. 282,807-815. 
Graboske, H. C., Jr., J. B. Pollack, A. S. Grossman, and R. J. Olness (1975). The structure and evolution of Jupiter, the fluzd contraction phase. Astrophys, If 199, 265-281.

Grant, I. P., and G. E. Hunt (1969). Discrete space theory of radiative transfer. I. Fundamentals. Proc, Roy, Soc. London Ser. A 313, 183-197.

Hanel, R., B. Conrath, F. M. Flager, V. Kunde, P. Lowman, W. Maguzre, J. C. Pearl, J. A. Plraglia, R. Samuelson, D. Gautzex, P. Gierasch, S. Kumar, and C. Ponnamperuma (1979). Infrared observations of the Jovian system from Voyager 1. Sczence 204, 972-976.

Hanel, R., B. Conrath, L. Herath, V. Kunde, and J. Pırraglia (1981). Albedo, internal heat, and energy balance of Jupiter: preliminary results of the voyager infrared investigation. If Geophys. Res. $86,8705-8712$.

Hanel, R., B. Conrath, F. M. Flaser, V. Kunde, w. Maguıre, J. Pearl, J. Piraglia, R. Samuelson, D. Crulkshank, D. Gautzer, P. Glerasch, I. Horn, and C. Ponnanperuma (1982). Infrared observations of the Saturnian system from voyager 2 . Science 215, 544-548.

hanei, R. A., B. J. Conrath, V. G. Kunde, J. C. Pearl and J. A. Pirraglia (1983). Albedo, internal heat flux and energy balance of Saturn. Icarus 53, 262-285.

Holmes, A. W. (1981). Light scattering from ammonia in water crystals. Ph.D. Thesis, The University of Arizona,

Holmes, A. H., R. Paxman, H. P. Stahl, and M.G. Tomasko (1980). Llght scattering by crystals of $\mathrm{NH}_{3}$ and $\mathrm{H}_{2} \mathrm{O}$. Bull, Amer. Astron. Soc. 
12, 705 .

Hubbard W. B., and J. J. MacFarlane (1980). Structure and evolution of Uranus and Neptunc. I Geophys, Res, 85 225-234.

Husson, N., A. Goldman, and G. Orton (1981). Spectroscopic line parameters of $\mathrm{NH}_{3}$ and $\mathrm{PH}_{3}$ in the far infrared. I Quant. Spectrosc. Radiat, Transfer 27, 505-515.

Husson, N., A. Chedın, N. A. Scott, I. Cohen-Hallaleh, and I. Berrolr (1982). La banque de donnees "GEISA"; Mise a jour no. 3 (Ju1llet 1982). Note Interne no. 116. Laboratolre de Meteorologie Dynamique, Ecole Polytechnıque, Palasseau, France.

Ingersol 1, A. P., G. Munch, G. Neugebauer, and G. S. Orton (1976). Results of the infrared radiometer experiment on Pioneers 10 and 11. Juplter ed. Gehrels, T. (University of Arlzona Press). Jaffe, D. T., R. H. HIldebrand, J. Keene, D. A. Harper, R, F. Loewensteın, and J. M. Moran (1984). Far-ınfrared selected star formation regions. Astrophys, I 281, 225-236.

Kllore, A. J., I. R. Patel, G. F. Lindal, D. N. Sweetnam, H. B. Holtz, J. H. Waite Jr., and T. R. MCDonough (1980). Structure of the lonosphere and atmosphere of Saturn from Ploneer 11 Saturn radio occultation. Jour, of Geophysical Research 85, 5857-5870. KleIn, M. J., M. A. Janssen, S. Gulkis, and E. T. Olsen (1978). Saturn's microwave spectrum: Implications for the atmosphere and the rings, in The saturn System, NASA Conf. Publ. 2068, edited by D. M. Hunten and D. Morrison, Pp. 195-216.

Kuhn, P. M., E. Magazıner, and I. P. Stearns (1976). Areal dıstrıbutzon 
of water vapor burdon above the troposphere. Geophys. Bes, Lett. 3 529 .

Kunde, V., R. Hanel, W. Maguıre, D. Gautıer, J.-P. Baluteau, A. Marten, A. Chedın, N. Husson, and N. Scott (1982). The tropospherıc gas composition of Juplter's North Equatorial Belt $\left(\mathrm{NH}_{3^{\prime}} \mathrm{PH}_{3^{\prime}} \mathrm{CH}_{3} \mathrm{D}\right.$ $\mathrm{GeH}_{4}, \mathrm{H}_{2} \mathrm{O}$ ) and the Jovian D/H 1sotoplc ratio. Astrophys, I. 263 , $443-467$.

Larson, H. P., U. Fink, and R. R. Treffers (1978). Evidence for Co in Jupıter's atmosphere from alrborne spectroscopıc observatıons at 5 microns. Astrophys, J. 219, 1084-1092.

Iındal, G. F., G. E. Wood, G. S. Levy, J. D. Anderson, D. N. Sweetnam, H. B. Hotz, B. J. Buckles, D. P. Holmes, P. E. Doms, V. R. Eshleman, G. L. Tyler, and T. A. Croft (1981). The atmosphere of Jupzter: an analysis of the voyager occultation measurements. $I$. Geophys, Res, $86,8721-8728$.

Lockwood, G. W., B. L. Lutz, D. T. Thompson, and A. Warnock ( 1983 ).

The albedo of Uranus. Astrophys, I, 266, 402-414.

Loewensteln, R. F., D. A. Harper, S. H. Moseley, C. M. Telesco, H. A. Thronson, R. H. Hzldebrand, S. E. Whitcomb, R. Winston, and R. F. stlenıng (1977a). Far infrared and submillimeter observatzons of the planefs, Icarus 31, 315-324.

Loewenstein, R. F., D. A. Harper, and S. H. Moseley (1977b). The effectzve temperature of Neptune. Astrophys, I. 218, LI $45-I I 4 \%$.

Martonchik, 4. V., G. S. Orton, and J. F. Appleby (1983). Optical properties of $\mathrm{NH}_{3}$ zce from the far infrared through the near 
ultraviolet. Appl, Qptics. 23 541-551.

MIshima, O., D. D. Klug, and E. Whalley (1983). The far infrared

spectrum of ice $T^{\prime}$ in the range $8-25 \mathrm{~cm}^{-1}$. Sound waves and difference bands, with application to Saturn's rings. I, chem. Rhys, 78 6399-6404.

Murphy, R. E., and L. M. Trafton (1974). Evidence for an internal heat source in Neptune. Astrophys. I. 193 253-255.

Neff, J. S., T. A. Ell1s, J. Apt, and J. T. Bergstralh (1984). Bolometric geometric albedos of Titan, Uranus and Neptune. Bull. Amer, Astron, Soc, 16, 665.

Neugebauer, G., G. Munch, H. Kıeffer, S. C. Chase Jr., and E. Miner, (1971). Marıner 1961 Infrared radıometer results: temperature and thermal properties of the Martian surface. Astron, I 76, 719-728. Newburn, R. L., Jr., and S. Gulkıs (1973). A survey of the outer planets Jupiter, Saturn, Uranus, Neptune, Pluto and their satellites. Space Science Rev, 14, 179-271.

Newburn, R. L., Jr., and S. Gulk1s (1975). Planets and satellites of the outer solar system, asterolds, and comets. In Foundations ef Space Bielogy and Medicine, Vol. I, NASA Spec. Publ. 274, edited by M. Calvin and O. G. Gazenko, pp. 197-268.

orton, G. S. (1981). Modification to Scott's method for direct integration of gaseous transmission to improve speed and accuracy. $I$. Quant. Spectros, Radiat. Transfer 26, 463-466.

Orton, G. S., H, H. Aumann, J. V. Martonchlk and J. F. Appleby (1982a). Alrborne spectroscopy of Jupiter in the $100-$ to $300-\mathrm{cm}^{-1}$ region: 
Global properties of ammonla gas and 1ce haze. Icarus 52, $81-93$.

Orton, G. S., J. F. Appleby and J. V. Martonch 1 k (1982b). The effect

of ammonia lce on the outgoing thermal radiance from the atmosphere of Jupiter. Icarus 52, 94-116.

Orton, G. S. (1983). Thermal infrared constraints on ammonia ice particles as candidates for clouds in the atmospheres of saturn. Icarus 53, 293-300.

Orton, G. S., A. T. Tokunaga, and J. Caldwell (1983). Observatıonal constraints on the atmospheres of Uranus and Neptune from new measurements near $10 \mathrm{~m}$. Icarus 56 147-164.

Orton, G. S., M. J. Griffen, P. Ade, I. G. Nolt, J. V. Radostztz, E. I. Robson, W. K. Gear (1985). Submillimeter and millimeter observatıons of Uranus and Neptune. Submitted to Icarus.

pirraglia, J. A., B. J. Conrath, M. D. Allison, and P. J. Gierasch (1981). Thermal structure and dynamics of Jupiter and Saturn. Nature 292, 677-679.

Pollack, J. B., and J. N. Cuzzl (1980). Scatterıng by nonspherıcal partıcles of size comparable to a wavelength: A new semzempirical theory and Its application to tropospheric aerosols. I. Atmos, Sc1 37, 868-881.

Pollack, J. B., K. Rages, D. Wenkert, G. E. Danıelson, J. Bergstralh, K. Baznes, and J. S. Neff (1984). A determination of the bolometric albedo of Uranus and Neptune. Bull. Amer. Astron. Soc. 16, 657 .

Scott, N. A. (1974). A direct method of computation of the transmission function of an inhomogeneous gaseous medium. I. 
Quant. Spectros, Radrat. Transfer 14, 691-704.

Sill, G., U. Fink, and J. R. Ferraro (1980). Absorption coefficients of solld $\mathrm{NH}_{3}$ from 50 to $7000 \mathrm{~cm}^{-1}$. I Opt. Soc. Amer. 70, 724739.

Simpson, J. P., J. N. Cuzz1, E. F. Erıckson, D. W. Strecker, and A. T. Tokunaga (1981). Mars: far infrared spectra and thermalemission models. Icarus $48,230-245$.

Stevenson, D. J. (1980). Saturn's luminosity and magnetısm. Sclence $208746-748$.

Stıer, M. T., W. A. Traub, G. G. Fazıo, E. L. Wright, F. J. Low (1978). Far-ınfrared observatıong of Uranus, Neptune, and Ceres. Astrophys, I, 226, 347-349.

Sweetnam, D. N. (1980). Viking radıo occultation studies of the shape of Mars Eos Trans, Am, Geophys, Unzon 61, \#46, P. 1020.

Tokunaga, A. T., H. L. Dinersteın, D. F. Lester, and D. M. Rank (1980). The phosphine abundance on Saturn derıved from new 10-micrometer spectra. Icarus $42,79-85$.

Tokunaga, A. T., G. S. Orton, J. Caldwell (1983). New observational constraints on the temperature inversions of Uranus and Neptune. Icarus 53, 141-146.

Traub, W. A. and M.T. Stıer, (1976). Theoretıcal atmospherıC transmission in the mid- and infrared at four altitudes. apol. opt, 15, 364-377.

Tyler, G. L., V. R. Eshleman, J. D. Anderson, G. S. Levy, G. F. Lindal, G. E. Wood, and T. A. Croft (1982). Radio science with Voyager 2 at 
Saturn: atmosphere and 1onosphere and the masses of Mimas, Tethys, and Iapetus. Sclence 215, 553-557

Ulzch, B. K. (1981). Mllimeter-wavelength continuum calibration sources. Astron. I. 86, 1619-1626.

Wallace, I. (1980). The structure of the Uranus atmosphere. Icarus 43, 231-259.

Wenkert, D. D., G. E. Danielson, and J. B. Pollack (1984). Imagıng of Uranus and Neptune from Voyager 1 and 2 and Implications for their Internal heat sources, B.A.A.S, 16, 659.

Whitcomb, S. E., R. H. Hzldebrand, and Jocelyn Keene, R. F. Stzenıng, and D. A. Harper (1979). Submillimeter brightness temperature of Venus, Jupiter, Uranus and Neptune. Icarus 38, 75-80.

Whitcomb, S. E., R. H. Hlldebrand, and J. Keene (1980). An f/35 submillimeter photometer for the NASA Infrared Telescope Facility. Pub, Astron. Soc. Pacific 92, 863-869.

Wright, E. I. (1976). Recalibratıon of the far-infrared brightnegs temperatures of the planets. Astrophys. I. 210, 250-253. Wright, E. I., and S. Odenwald (1980). Brightness temperature of Mars. Bul. Amer. Astron. Soc, 12, 456. 
Figure l: Transmission curves of the IRTF filters. The curves are labeled with the fliter names used in the tables.

Figure 2: Transmission curves of the KAO fllters. The curves are labeled with the filter names used in the tables.

Figure 3: The brightness temperature of Jupiter from KAO (circles) and IRTF (triangles). The dashed curve represents an initially assumed spectrum from which the solid curve was derived using an iterative procedure.

Numbers in parentheses indicate the number of data points occuring at that coordinate.

Errors are shown for the IRTF data, and are the statıstical standard deviation of all measurements at that wavelength. No errors are shown for the RAO data, since statıstıcal errors are small compared to systematic effects; instead, each measurement is plotted. The spread can be used to judge the extent of systematıc errors.

Figure 4: The brightness temperature of Saturn. see Figure 3 caption.

Pigure 5: The brightness temperature of Uranus. See Figure 3 captıon.

Figure 6: The brightness temperature of Neptune. See Figure 3 caption.

Figure 7: Flux densities of Jupiter and saturn. The curves correspond to the final derived (solid) curves in Frgures 3 and 4 . The individual data points are adjusted to a fixed planetary solid angle, and errors 
shown are the standard deviation of the mean of the values of all observations at that wavelength.

Figure 8: Flux densities of Uranus and Neptune. The curves correspond to the final derıved (solid) curves in Figures 5 and 6 . See Figure 7 caption.

Figure 9: Spectra of Jupiter for models wath no $\mathrm{NH}_{3}$ cloud (upper curve), and for a cloud with a ratio of partıcle to gas scale helghts $\mathrm{H}_{\mathrm{P}} / \mathrm{H}_{\mathrm{g}}=0.15$ and partıcle sizes of $30 \mu \mathrm{m}$ (middle curve) and $100 \mu \mathrm{m}$ (lower curve). The spectra are computed with resolution element of 10 $\mathrm{cm}^{-1}$ through $100 \mu \mathrm{m}\left(100 \mathrm{~cm}^{-1}\right), 5 \mathrm{~cm}^{-1}$ between $100 \mu \mathrm{m}$ and $200 \mu \mathrm{m}(50-100$ $\mathrm{cm}^{-1}$ ) and $2.5 \mathrm{~cm}^{-1}$ between $200 \mu \mathrm{m}$ and $1 \mathrm{~mm}\left(10-40 \mathrm{~cm}^{-1}\right)$. The spectrum at short wavelengths is taken from whole-disk voyager IRIS average of Hanel et al. (1981). T1c marks in the upper graph denote the positions of strong lines or manifolds of $\mathrm{NH}_{3}$ and $\mathrm{PH}_{3}$.

Figure 10: Spectra of Jupiter for models with $\mathrm{H}_{\mathrm{p}} / \mathrm{H}_{\mathrm{g}}=0.50$ and particle sizes of $10 \mu \mathrm{m}$ (upper curve) and $100 \mu \mathrm{m}$ (lower curve). Other symbols are shown as in Fig. 9.

Figure 11: Spectra of Jupiter for models with $\mathrm{H}_{\mathrm{p}} / \mathrm{H}_{\mathrm{g}}=0.05$ and particle sizes of $10 \mu \mathrm{m}$ (upper curve) and $100 \mu \mathrm{m}$ (lower curve). Other symbols are shown as in Fig. 9.

Figure 12: Spectra of Saturn for models with various $\mathrm{pH}_{3}$ mixing ratios. The curves represent spectra of models with the mixing ratio of $\mathrm{PH}_{3}$ equal to $1.5 \times 10^{-6}$ (upper curve), $3 \times 10^{-6}$ (mldale curve) and 1 
$x 10^{-5}$ (lower curve). The mixing ratıo of $\mathrm{NH}_{3}$ in the deep atmosphere equals $2 \times 10^{-4}$. Spectra are computed with resolution elements as given in Fig. 9. TIC larks in the upper graph have the same meaning as In Fig. 9 .

Figure 13: Temperature structures of Uranus used in the models for a 908 mixing ratıo of $\mathrm{H}_{2}$. Each $1 \mathrm{~s}$ a perturbation of the profile given by Tokunaga et al. ( 1982 ) which 19 nearly Identical to the structures shown above the adiabatic region. The difference in temperature structures in the troposphere is the result of different wet adiabatic lapse rates associated with a variety of $\mathrm{CH}_{4}$ mixing ratios in the deep atmosphere as shown.

Figure 14: Spectra of Uranus for $908 \mathrm{H}_{2}$ derıved from the temperature structures shown in Fig. 13. Only the absorption of the collisioninduced dipole of $\mathrm{H}_{2} 19$ considered in the models. Our data are shown by the filled circles. The 28 and $48 \mathrm{CH}_{4}$ spectra are indistinguishable at this scale near $50 \mathrm{~m}$. From 10.3 to $19.6 \mathrm{~m}$, the observations of Tokunaga et al. (1983) and orton et al. (1983) are also shown as filled circles.

Figure 15: Temperature structures of Neptune used in the models for a 908 mıxing ratıo of $\mathrm{H}_{2}$. Each is a perturbation of the profile given by Tokunaga et al. (1983), optımızed to provide a best fit to our data between 40 and $100 \mathrm{~m}$. The difference in tropospheric temperatures arzses for the same reasons as for Uranus (F1g. 13). 
Figure 16: Spectra of Neptune for $90 \% \mathrm{H}_{2}$ derived from the temperature structures shown in Figure 15, Only the absorption of the collisioninduced $\mathrm{H}_{2}$ dipole 13 considered in the models. The 28 and $48 \mathrm{CH}_{4}$ spectra are indistinguishable at this scale near $50 \mu \mathrm{m}$. From 10.3-to 19.6- $\mu \mathrm{m}$, the observations of Tokunaga et al. (1983) and orton et al. (1983) are also shown as filled circles. 
TABLE I

ASSUMED PLANETARY RADII (1-bar) a

\begin{tabular}{lccc}
\hline Planet & $\begin{array}{c}\text { Eguatorial Radius } \\
\text { Rea } \\
(\mathrm{km})\end{array}$ & Ellipticityb & $\begin{array}{c}\text { Pole Inclination } \\
\text { min }\end{array}$ \\
\hline Mars & 3397 & 0.006 & $111^{\circ}-115^{\circ}$ \\
Jupiter & 71495 & 0.065 & $87^{\circ}-89^{\circ}$ \\
Saturn & 60233 & 0.006 & $88^{\circ}-92^{\circ}$ \\
Uranus & 25563 & 0.024 & $19^{\circ}-27^{\circ}$ \\
Neptune & 24760 & 0.021 & $69^{\circ}-71^{\circ}$
\end{tabular}

a See Section III for references.

b $\varepsilon=\left(R_{e q}-R_{p}\right) / R_{e q}$ where $R_{e q}$ and $R_{p}$ are the equaiorial and polar radii.

c Range of angles between the planet pole and the line of sight during the observation. 
TABLE II

JOURNAL OF OBSERVATIONS BROADBAND DATA

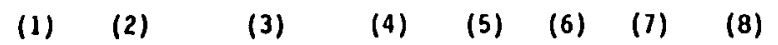

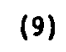

(10) (11) (12) (13)

(14)

(15)

(16)

\begin{tabular}{|c|c|c|c|c|c|c|c|c|c|c|c|c|c|c|c|c|c|c|c|}
\hline \multirow{3}{*}{$\begin{array}{l}\text { Line } \\
\\
1 \\
2 \\
3\end{array}$} & \multicolumn{2}{|c|}{ Planet } & \multirow{2}{*}{\multicolumn{3}{|c|}{$\begin{array}{l}\text { Date } \\
\text { (UT) }\end{array}$}} & \multirow{2}{*}{ Filter } & \multicolumn{2}{|c|}{$\begin{array}{l}\text { e.o.s. } \\
\mathrm{H}_{2} \mathrm{O}\end{array}$} & \multirow{2}{*}{$\begin{array}{c}\text { Zenith } \\
\mathrm{H}_{2} \mathrm{O} \\
(\mathrm{mm})\end{array}$} & \multirow{2}{*}{$\begin{array}{l}\lambda^{\mathrm{a}} \\
(\mu \mathrm{m})\end{array}$} & \multirow{2}{*}{\multicolumn{2}{|c|}{$\begin{array}{l}\text { Signal ratto } \\
S(a) / S(b)\end{array}$}} & \multicolumn{2}{|c|}{$\begin{array}{l}\text { Semi- } \\
\text { di ameter }\end{array}$} & \multicolumn{2}{|c|}{$\begin{array}{l}\text { Finite disk } \\
\text { correction }\end{array}$} & \multirow{2}{*}{$\begin{array}{l}\text { Brightness } \\
\text { ratiod } \\
B(a) / B(b)\end{array}$} & \multicolumn{2}{|c|}{$\begin{array}{c}\text { Planet } \\
\text { temperature }\end{array}$} \\
\hline & $\mathbf{a}$ & b & & & & & $\begin{array}{l}W(a) \\
(m+n)\end{array}$ & $\begin{array}{l}w(b) \\
(m \mathrm{~m})\end{array}$ & & & & & $\begin{array}{l}\Delta(\mathrm{a}) \\
\text { (arc }\end{array}$ & $\begin{array}{l}\Delta(a) \\
\sec )\end{array}$ & $O(a)$ & $D(b)$ & & $\begin{array}{c}T(b)^{e} \\
(x)\end{array}$ & $T(d)^{j}$ \\
\hline & $\begin{array}{l}\text { Jup } \\
\text { Jup } \\
\text { Jup } \\
\text { Jup }\end{array}$ & $\begin{array}{l}\text { Mars } \\
\text { Mars } \\
\text { Mars }\end{array}$ & $\begin{array}{l}1979 \\
1979 \\
1980\end{array}$ & $\begin{array}{l}\text { Nov } \\
\text { Nov } \\
\text { Feb }\end{array}$ & $\begin{array}{l}27 \\
28 \\
21\end{array}$ & $\begin{array}{l}\mathrm{CH} 2 \\
\mathrm{CH} 2 \\
\mathrm{CH} 2 \\
\mathrm{CH} 2\end{array}$ & $\begin{array}{l}1.1 \\
1.4 \\
0.9\end{array}$ & $\begin{array}{l}1.2 \\
1.4 \\
0.9\end{array}$ & $\begin{array}{l}1.0 \\
1.2 \\
0.7\end{array}$ & $\begin{array}{l}418 \\
428 \\
411\end{array}$ & $\begin{array}{r}14.23 \\
13.97 \\
5.36\end{array}$ & $\begin{array}{l} \pm 0.18 \\
\pm 0.17 \\
\pm 0.38\end{array}$ & $\begin{array}{l}17.78 \\
17.83 \\
21.64\end{array}$ & $\begin{array}{l}3.66 \\
3.69 \\
6.86\end{array}$ & $\begin{array}{l}1.185 \\
1.186 \\
1.306\end{array}$ & $\begin{array}{l}1006 \\
1.006 \\
1.020\end{array}$ & $\begin{array}{l}0.710 \pm 0.009 \\
0.705 \pm 0.009 \\
0.690 \pm 0.049\end{array}$ & $\begin{array}{l}213 \\
213 \\
213.5\end{array}$ & $\begin{array}{l}155.9 \pm 1.8 \\
154.8 \pm 1.8 \\
152.4 \pm 9.7 \\
\frac{152.4 \pm}{155.3 \pm 1.39}\end{array}$ \\
\hline $\begin{array}{l}4 \\
5\end{array}$ & $\begin{array}{l}\text { Jup } \\
\text { Jup } \\
\text { Jup }\end{array}$ & $\begin{array}{l}\text { Mars } \\
\text { Mars }\end{array}$ & $\begin{array}{l}1980 \\
1980\end{array}$ & $\begin{array}{l}\text { May } \\
\text { May }\end{array}$ & $\begin{array}{l}23 \\
25\end{array}$ & $\begin{array}{l}\text { MP2 } \\
\text { MP2 } \\
\text { MP2 }\end{array}$ & $\begin{array}{l}4.5 \\
5.9\end{array}$ & $\begin{array}{l}4.4 \\
5.9\end{array}$ & $\begin{array}{l}2.7 \\
4.5\end{array}$ & $\begin{array}{l}952 \\
992\end{array}$ & $\begin{array}{l}19.34 \\
17.82\end{array}$ & $\begin{array}{l} \pm 1.82 \\
\pm 1.16\end{array}$ & $\begin{array}{l}17.89 \\
17.79\end{array}$ & $\begin{array}{l}3.89 \\
3.83\end{array}$ & $\begin{array}{l}.030 \\
.029\end{array}$ & $\begin{array}{l}1.000 \\
1.000\end{array}$ & $\begin{array}{l}0.942 \pm 0.089 \\
0.850 \pm 0056\end{array}$ & $\begin{array}{l}199 \\
199\end{array}$ & $\begin{array}{l}187.9 \pm 171 \\
170.2 \pm 10 \frac{1}{10} \\
175.1 \pm 10.09\end{array}$ \\
\hline $\begin{array}{l}6 \\
7 \\
8\end{array}$ & $\begin{array}{l}\text { Sat } \\
\text { Sat } \\
\text { Sat } \\
\text { Sat }\end{array}$ & $\begin{array}{l}\text { Mars } \\
\text { Mars } \\
\text { Mars }\end{array}$ & $\begin{array}{l}1979 \\
1979 \\
1980\end{array}$ & $\begin{array}{l}\text { Nov } \\
\text { Nov } \\
\text { Feb }\end{array}$ & $\begin{array}{l}27 \\
28 \\
21\end{array}$ & $\begin{array}{l}\mathrm{CH} 2 \\
\mathrm{CH} 2 \\
\mathrm{CH} 2 \\
\mathrm{CH} 2\end{array}$ & $\begin{array}{l}1.2 \\
1.4 \\
0.8\end{array}$ & $\begin{array}{l}1.2 \\
1.4 \\
0.9\end{array}$ & $\begin{array}{l}1.0 \\
1.2 \\
0.7\end{array}$ & $\begin{array}{l}421 \\
428 \\
410\end{array}$ & $\begin{array}{l}2.52 \\
2.50 \\
0.843\end{array}$ & $\begin{array}{ll} \pm & 0.03 \\
\pm & 0.04 \\
\pm & 0.065\end{array}$ & $\begin{array}{l}8.13 \\
9.27\end{array}$ & $\begin{array}{l}3.66 \\
3.69 \\
6.86\end{array}$ & $\begin{array}{l}1.032 \\
1.031 \\
1.042\end{array}$ & $\begin{array}{l}1.006 \\
1.009 \\
1.020\end{array}$ & $\begin{array}{l}0.525 \pm 0.006 \\
0.526 \pm 0.009 \\
0.471 \pm 0.037\end{array}$ & $\begin{array}{l}213 \\
213.5\end{array}$ & $\begin{array}{l}119.4 \pm 1.2 \\
119.5 \pm 1.8 \\
109.1 \pm 7.3 \\
\frac{119.2 \pm}{11.29}\end{array}$ \\
\hline $\begin{array}{r}9 \\
10\end{array}$ & $\begin{array}{l}\text { Sat } \\
\text { Sat } \\
\text { Sat }\end{array}$ & $\begin{array}{l}\text { Mars } \\
\text { Mars }\end{array}$ & $\begin{array}{l}1980 \\
1980\end{array}$ & May & $\begin{array}{l}23 \\
25\end{array}$ & $\begin{array}{l}\text { MP2 } \\
\text { MP2 } \\
\text { MP2 }\end{array}$ & $\begin{array}{l}3.4 \\
5.4\end{array}$ & $\begin{array}{l}4.4 \\
5.9\end{array}$ & $\begin{array}{l}2.7 \\
4.5\end{array}$ & $\begin{array}{l}936 \\
986\end{array}$ & $\begin{array}{l}3.33 \\
3.35\end{array}$ & $\begin{array}{l} \pm 0.17 \\
\pm 0.10\end{array}$ & & $\begin{array}{l}3.89 \\
3.83\end{array}$ & $\begin{array}{l}1.006 \\
1.007\end{array}$ & $\begin{array}{l}1.000 \\
1.000\end{array}$ & $\begin{array}{l}0.673 \pm 0.035 \\
0.661 \pm 0.019\end{array}$ & $\begin{array}{l}199 \\
199\end{array}$ & $\begin{array}{l}136.4 \pm 6.7 \\
133.9 \pm 3.6 \\
134.5 \pm 3.2\end{array}$ \\
\hline 11 & Ur & Jup & 1981 & Mar & 1 & $\mathrm{CH} 2$ & 0.4 & 0.4 & 0.3 & 394 & $(4.047$ & $\pm 0.062) 10^{-3}$ & 1.89 & 20.93 & 1.000 & 1.280 & $0.388 \pm 0.006$ & $155.3 \pm 1.3$ & $70.1 \pm 1.3$ \\
\hline $\begin{array}{l}12 \\
13 \\
14 \\
15\end{array}$ & $\begin{array}{l}\text { Ur } \\
\text { Ur } \\
\text { Ur } \\
\text { Ur }\end{array}$ & $\begin{array}{l}\text { Mars } \\
\text { Sat } \\
\text { Mars } \\
\text { Mars }\end{array}$ & $\begin{array}{l}1980 \\
1980 \\
1980 \\
1980\end{array}$ & $\begin{array}{l}\text { May } \\
\text { May } \\
\text { May } \\
\text { Jul }\end{array}$ & $\begin{array}{l}23 \\
24 \\
25 \\
28\end{array}$ & $\begin{array}{l}\text { MP2 } \\
\text { MP2 } \\
\text { MP2 } \\
\text { MP2 }\end{array}$ & $\begin{array}{l}3.5 \\
6.8 \\
6.3 \\
8.4\end{array}$ & $\begin{array}{l}4.4 \\
8.5 \\
5.9 \\
8.4\end{array}$ & $\begin{array}{l}2.7 \\
5.3 \\
4.5 \\
6.4\end{array}$ & $\begin{array}{r}937 \\
1020 \\
997 \\
1012\end{array}$ & $\begin{array}{l}0.130 \\
0.038 \\
0.129 \\
0.209\end{array}$ & $\begin{array}{l} \pm 0.020 \\
\pm 0.002 \\
\pm 0.011 \\
\pm 0.007\end{array}$ & $\begin{array}{l}1.98 \\
1.98 \\
1.91\end{array}$ & $\begin{array}{l}3.89 \\
8.66 \\
3.83 \\
2.76\end{array}$ & $\begin{array}{l}1.000 \\
1.000 \\
1.000 \\
1.000\end{array}$ & $\begin{array}{l}1.000 \\
1007 \\
1.000 \\
1.000\end{array}$ & $\begin{array}{l}0.502 \pm 0.077 \\
0.722 \pm 0.038 \\
0.483 \pm 0.041 \\
0.436 \pm 0.014\end{array}$ & $\begin{array}{l}199 \\
134.5 \pm 3.2 \\
199 \\
203\end{array}$ & $\begin{array}{r}103.6 \pm 14.8 \\
99.0 \pm 5.3 \\
99.7 \pm 7.5 \\
92.4 \pm 2.7 \\
94.5 \pm 2.39\end{array}$ \\
\hline 16 & Nept & Jup & 1981 & Mar & 1 & $\mathrm{CH} 2$ & 0.4 & 0.4 & 0.3 & 394 & $(1.340$ & $\pm 0.023) 10^{-3}$ & 1.11 & 20.93 & 1.000 & 1.280 & $0.372 \pm 0.006$ & $155.3 \pm 1.3$ & $67.9 \pm 1.2$ \\
\hline $\begin{array}{l}17 \\
18 \\
19\end{array}$ & $\begin{array}{l}\text { Nept } \\
\text { Nept } \\
\text { Nept } \\
\text { Nept }\end{array}$ & $\begin{array}{l}\text { Ur } \\
\text { Mars } \\
\text { Mars }\end{array}$ & $\begin{array}{l}1980 \\
1980 \\
1980\end{array}$ & $\begin{array}{l}\text { Jul } \\
\text { Jul } \\
\text { Jul }\end{array}$ & & $\begin{array}{l}\text { MP2 } \\
\text { MP2 } \\
\text { MP2 } \\
\text { MP2 }\end{array}$ & $\begin{array}{l}5.8 \\
9.0 \\
6.6\end{array}$ & $\begin{array}{l}6.2 \\
8.4 \\
5.8\end{array}$ & $\begin{array}{l}4.3 \\
6.4 \\
4.4\end{array}$ & $\begin{array}{r}995 \\
1015 \\
1000\end{array}$ & $\begin{array}{l}0.352 \\
0.086 \\
0.112\end{array}$ & $\begin{array}{l} \pm 0.050 \\
\pm 0.008 \\
\pm 0.023\end{array}$ & $\begin{array}{l}1.15 \\
1.14 \\
1.14\end{array}$ & $\begin{array}{l}1.91 \\
2.76 \\
2.73\end{array}$ & $\begin{array}{l}1.000 \\
1.000 \\
1.000\end{array}$ & $\begin{array}{l}1.000 \\
1.000 \\
1.000\end{array}$ & $\begin{array}{l}0.971 \pm 0138 \\
0.504 \pm 0.047 \\
0.642 \pm 0.133\end{array}$ & $\begin{array}{l}98.5 \pm 2.3 \\
203 \\
203.5\end{array}$ & $\begin{array}{c}92.0 \pm 12.1 \\
105.7 \pm 9.2 \\
133.1 \pm 26.1 \\
103.0 \pm 7.2^{9}\end{array}$ \\
\hline
\end{tabular}

b) Wavelength corresponding to effective frequency as given in equation (2) of text, for water vapor $=\frac{1}{2}[w(a)+w(b)]$. See footnote $f$. based on assumed radif shown in Table IV.

d) $B(a) / B(b)=[S(a) / S(b)][\phi(b) / \$(a)]^{2}[D(a) / D(b)]$

e) Mars temperatures based on Wright's model (1980) assuming no wavelength dependence for $\lambda \geq 350$ um. Other temperatures from rable $V$.

f) For filters CH2 and MP2, $T(a)$ is insensitive to $A$ (colum 8 ) and hence to $w(a)$ and $w(b)$ (columns 5 and 6 ).

g) Average of values for same planet and filter. 
-AaLE III

JOURMAL OF OBSERVATIONS: MARROWER BANO DATA
$\therefore(2)$
(3)
(4)
(5)
(6)
(7)

(8)

(9)

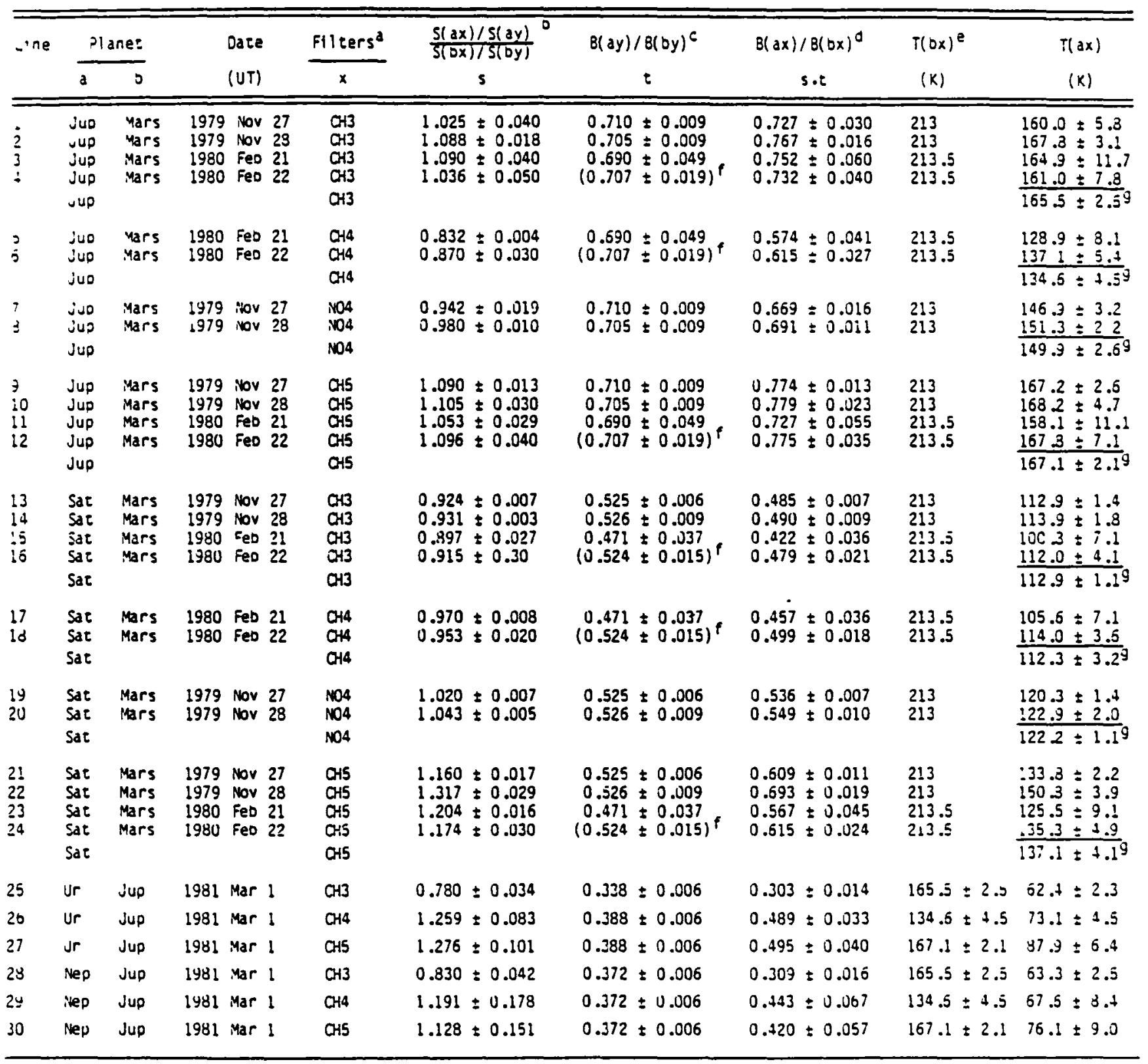

afileer y is 0h2 in every case.

${ }^{0} S(a x) / S(a y)=$ ratio of signal from planet a with filter $x$ (column 4) to signal som planet a with filter y (CH2), etc. The siynal ratios have been corrected to $1 \mathrm{~mm}$ line-of-sight water vapor for filters CH2, CH3, CH4, NO4, and CH5, and 0 arm line-of-signt water vapor for MP2. The corresponding wavelengens are 414, 353, 450, 517, 664(1mm), and 930(5mm).

$E_{g}(a y)=$ origneness of planet a with filter $y$, etc. The values of the brigheness ratios are taxen from taole II column (14) using data from the saine dates except as otherwise noted (footnote f)

a Coluinn (5) times column (6).

eassumed oriyntness temperature of planet $D$, filter $x$ based on Wright's model (see Section III of text), where plane: o is Mars, and on the results shown in Table $V$, where planet $b$ is Jupiter.

faveraye of earlier data on $B(a y) / B(b y)$ for same planets with error multiplied by 3 . (No direct measurenent of $8(a y) / B(D y)$ on Feoruary 22.$)$

yzieraye of values for same planet and filter. 
aur $n$

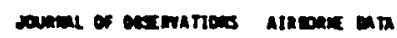

\begin{tabular}{|c|c|c|c|c|c|c|c|c|c|c|c|c|c|c|}
\hline \multirow{3}{*}{$\frac{1}{4 m}$} & \multicolumn{2}{|c|}{ (1) (2) } & \multirow{3}{*}{$\frac{\text { (3) }}{\text { onte }}$} & \multirow{3}{*}{$\frac{(1)}{\substack{\text { Mleep } \\
\text { (Aporture) }}}$} & \multirow{2}{*}{\multicolumn{2}{|c|}{$\frac{\text { (5) (6) }}{\sum_{z} 0^{3}}$}} & \multirow{3}{*}{$\frac{(7)}{\substack{\text { signel } \\
\text { not } 10^{\circ}}}$} & \multirow{2}{*}{\multicolumn{2}{|c|}{ 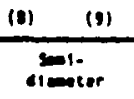 }} & \multirow{2}{*}{\multicolumn{2}{|c|}{ 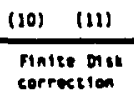 }} & \multirow{3}{*}{$\frac{(12)}{1}$} & \multirow{3}{*}{$\begin{array}{l}\frac{(1)}{\text { nur }_{\text {Onsity }}} \\
\text { (Jy' }\end{array}$} & \multirow{3}{*}{ 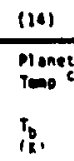 } \\
\hline & \multicolumn{2}{|c|}{ Namee } & & & & & & & & & & & & \\
\hline & 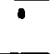 & $\bullet$ & & & (a) & $(0)$ & & $\begin{array}{l}\text { Nol } \\
\text { iars }\end{array}$ & $\underset{|c| c \mid}{d(0)}$ & $\overline{D(0)}$ & $\overline{a(1)}$ & & & \\
\hline & - & & 2000 & & & & & & & & & & & \\
\hline $\begin{array}{c}1 \\
\vdots \\
\vdots \\
\vdots \\
\vdots \\
10\end{array}$ & $\begin{array}{l}\text { Jup } \\
\text { Jup } \\
\text { Jup } \\
\text { Jup } \\
\text { Jup } \\
\text { Jup } \\
\text { Jupp } \\
\text { Jup } \\
\text { Jup } \\
\text { Jup }\end{array}$ & $\begin{array}{l}\text { Mors } \\
\text { Mors } \\
\text { Mars } \\
\text { Mors } \\
\text { Mors } \\
\text { Mors } \\
\text { Mors } \\
\text { Mors } \\
\text { mors }\end{array}$ & 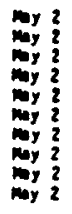 & 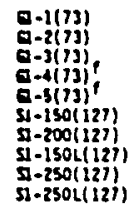 & $\begin{array}{l}6.3 \\
6.3 \\
5.8 \\
5.9 \\
6.3 \\
5.8 \\
7.3 \\
6.5 \\
6.9\end{array}$ & $\begin{array}{l}12 \\
6.1 \\
6.7 \\
3.4 \\
3.5 \\
6.3 \\
3.0 \\
5.2 \\
6.5\end{array}$ & 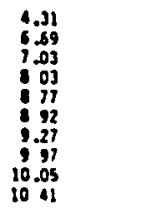 & $\begin{array}{l}19.03 \\
19.03 \\
19.03 \\
19.03 \\
19.03 \\
19.03 \\
19.03 \\
19.03 \\
19.03 \\
19.03\end{array}$ & $\begin{array}{l}4.54 \\
1.54 \\
1.54 \\
1.54 \\
4.54 \\
154 \\
154 \\
1.54 \\
154 \\
154\end{array}$ & $\begin{array}{l}1.097 \\
1.097 \\
1097 \\
1.097 \\
1.097 \\
1.031 \\
1.001 \\
1.031 \\
1.031 \\
1.031\end{array}$ & $\begin{array}{l}1.005 \\
1.05 \\
1.005 \\
1.005 \\
1.005 \\
1.002 \\
1.02 \\
1.02 \\
1.002 \\
1.002\end{array}$ & $\begin{array}{ll}30.7 \\
55 & 1 \\
62 & 6 \\
109 & \vdots \\
160 & 2 \\
335.4 \\
167 \\
204 & 0 \\
221 & 0 \\
328 & 8\end{array}$ & $\begin{array}{r}1210000 \\
1130000 \\
\$ 14000 \\
\$ 11000 \\
211000 \\
330000 \\
210000 \\
178000 \\
156000 \\
\$ 3900\end{array}$ & $\begin{array}{l}1349 \\
1385 \\
129.0 \\
131.5 \\
118.8 \\
128.1 \\
1119 \\
132 \\
133 \\
1437\end{array}$ \\
\hline $\begin{array}{l}11 \\
12 \\
13 \\
13 \\
15 \\
16 \\
17 \\
18 \\
19 \\
20\end{array}$ & 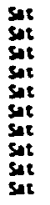 & $\begin{array}{l}\text { Mors } \\
\text { Mars } \\
\text { Mors } \\
\text { Mors } \\
\text { Mrs } \\
\text { wors } \\
\text { mors } \\
\text { Mars } \\
\text { Mers } \\
\text { Mors }\end{array}$ & $\begin{array}{l}\text { Jan } 16 \\
\operatorname{Jan} 16 \\
\operatorname{dan} 16 \\
\operatorname{Jan} 16 \\
\operatorname{Jan} 16 \\
\operatorname{Jan} 16 \\
\operatorname{Jan} 16 \\
\operatorname{Jan} 16 \\
\operatorname{Jan} 16 \\
\operatorname{Jan} 16\end{array}$ & $\begin{array}{l}q-1(19) \\
g-1(19) \\
g-2(19) \\
0-3(19) \\
g-4(19) 9 \\
g-5(19) \\
51-100(127) \\
51-150(127) \\
51-200(127) \\
51-150 L(127) \\
51-250 L(127)\end{array}$ & $\begin{array}{l}? \\
1 \\
: 0 \\
90 \\
9.0 \\
90 \\
9.0 \\
9 \\
9.0 \\
9.0\end{array}$ & $\begin{array}{l}17 \\
6.9 \\
7.6 \\
3.5 \\
15 \\
6.8 \\
6.9 \\
69 \\
63\end{array}$ & $\begin{array}{l}0.202 \\
0.442 \\
0.513 \\
0.606 \\
0.732 \\
0.568 \\
0.771 \\
0.838 \\
0.903 \\
1.033\end{array}$ & $\begin{array}{l}8.83 \\
8.83 \\
8.83 \\
8.83 \\
8.83 \\
8.83 \\
8.83 \\
8.83 \\
8.83 \\
8.83\end{array}$ & $\begin{array}{l}5.51 \\
5.51 \\
5.51 \\
5.51 \\
551 \\
5.51 \\
5.51 \\
551 \\
5.51 \\
551\end{array}$ & $\begin{array}{l}1.046 \\
1.046 \\
1.046 \\
1.046 \\
1.046 \\
1.007 \\
1.007 \\
1.007 \\
1.007 \\
1.007\end{array}$ & $\begin{array}{l}1.018 \\
1.018 \\
1.018 \\
1.018 \\
1.018 \\
1.03 \\
1.003 \\
1.03 \\
1.03 \\
1.003\end{array}$ & $\begin{array}{rl}40 & 2 \\
56 & 1 \\
4 & 9 \\
102 & .8 \\
146 & 5 \\
99 & \vdots \\
135 & 5 \\
168.5 \\
205.2 \\
331.5\end{array}$ & $\begin{array}{r}96500 \\
113000 \\
112000 \\
68000 \\
12500 \\
67800 \\
46600 \\
33500 \\
25300 \\
12900\end{array}$ & $\begin{array}{c}99 \\
109 \\
103 \\
99.3 \\
99 \\
97.3 \\
97.6 \\
96 \\
98 \\
109 \\
99\end{array}$ \\
\hline $\begin{array}{l}21 \\
22 \\
23 \\
24 \\
25 \\
26 \\
27 \\
28 \\
29 \\
30\end{array}$ & $\begin{array}{l}\text { Set } \\
\text { set } \\
\text { Sitt } \\
\text { Sit } \\
\text { Sit } \\
\text { Sit } \\
\text { Sit } \\
\text { Set } \\
\text { Sat } \\
\text { Set }\end{array}$ & $\begin{array}{l}\text { Mers } \\
\text { Murs } \\
\text { Mrs } \\
\text { Mars } \\
\text { Mrs } \\
\text { Mars } \\
\text { Mars } \\
\text { Mars } \\
\text { Mors } \\
\text { Mars }\end{array}$ & 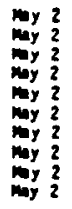 & 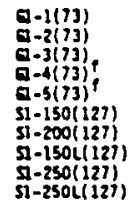 & $\begin{array}{l}78 \\
75 \\
75 \\
8 \\
8 \\
8 \\
8 \\
8 \\
9 \\
9.3 \\
8 \\
8\end{array}$ & $\begin{array}{l}6.2 \\
6.1 \\
6.7 \\
5.4 \\
5.2 \\
6.3 \\
3.0 \\
1.0 \\
5.7 \\
6.8\end{array}$ & $\begin{array}{l}0.320 \\
0.728 \\
0.370 \\
1.20 \\
1.38 \\
1.29 \\
1.32 \\
1.4 \\
1.40 \\
1.72\end{array}$ & $\begin{array}{l}896 \\
896 \\
896 \\
896 \\
8.96 \\
8.96 \\
8.96 \\
896 \\
896\end{array}$ & $\begin{array}{l}154 \\
154 \\
454 \\
154 \\
1.54 \\
454 \\
154 \\
454 \\
1.54 \\
1.54\end{array}$ & $\begin{array}{l}1.021 \\
1.021 \\
1.021 \\
1.021 \\
1.021 \\
1.007 \\
1.007 \\
1.007 \\
1.007 \\
1.007\end{array}$ & $\begin{array}{l}1.005 \\
1.005 \\
1.005 \\
1.005 \\
1.005 \\
1.002 \\
1.002 \\
1.002 \\
1.002 \\
1.002\end{array}$ & $\begin{aligned} 40.2 \\
36.2 \\
65.9 \\
110.8 \\
169.3 \\
135.5 \\
168.2 \\
205.2 \\
222.2 \\
331.6\end{aligned}$ & $\begin{array}{r}91700 \\
112000 \\
113000 \\
66800 \\
35100 \\
49900 \\
33600 \\
25400 \\
21600 \\
12900\end{array}$ & $\begin{array}{rl}90 & 8 \\
1003 & 3 \\
103 & 8 \\
101 & 7 \\
98 & 1 \\
100 & 0 \\
94 & 6 \\
96 & 3 \\
94 & 1 \\
106 & 9\end{array}$ \\
\hline $\begin{array}{l}31 \\
32 \\
33 \\
31\end{array}$ & $\begin{array}{l}\text { set } \\
\text { Set } \\
\text { Set } \\
\text { Sit }\end{array}$ & $\begin{array}{l}\text { Mars } \\
\text { Mors } \\
\text { Mars } \\
\text { Mors }\end{array}$ & $\begin{array}{ll}\text { my } & 13 \\
\text { nyy } & 13 \\
\text { ny } & 13 \\
\text { ny } & 13\end{array}$ & $\begin{array}{l}\mathrm{g}-1(73) \\
\mathrm{g}-2(73) \\
\mathrm{d}-4(73) \\
\mathrm{a}-5(73)\end{array}$ & $\begin{array}{l}9.3 \\
9 \\
9 \\
9 \\
9\end{array}$ & $\begin{array}{l}81 \\
1.6 \\
81 \\
10\end{array}$ & 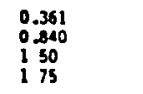 & $\begin{array}{l}8.81 \\
1.81 \\
8.81 \\
811\end{array}$ & $\begin{array}{l}4.17 \\
117 \\
4 \\
117\end{array}$ & $\begin{array}{l}1.020 \\
1.020 \\
1.020 \\
1.020\end{array}$ & $\begin{array}{l}1.005 \\
1.005 \\
1.005 \\
1.005\end{array}$ & $\begin{array}{r}40.2 \\
562 \\
1109 \\
1697\end{array}$ & $\begin{array}{r}80800 \\
105000 \\
67200 \\
36600\end{array}$ & $\begin{array}{cc}96 & 2 \\
99 & 1 \\
104 & 0 \\
103 & 4\end{array}$ \\
\hline $\begin{array}{l}35 \\
36 \\
37 \\
38 \\
39 \\
40 \\
41 \\
42 \\
43 \\
4\end{array}$ & $\begin{array}{l}\text { ur } \\
\text { wr } \\
\text { ur } \\
\text { ur } \\
\text { ur } \\
\text { wr } \\
\text { ur } \\
\text { ur } \\
\text { ur } \\
\text { ur }\end{array}$ & $\begin{array}{l}\sin \\
\sin t \\
\sin t \\
\sin t \\
\sin t \\
\sin t \\
\sin t \\
\sin \\
\sin \\
\sin t\end{array}$ & 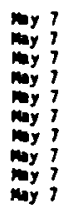 & $\begin{array}{l}g-1(49) \\
g-2(49) \\
g-2(49), \\
g--4(49) f \\
g-5(49) f \\
g 1-150(127) \\
51-200(127) \\
51-150 L(127) \\
5-250(127) \\
s 1-250 L(127)\end{array}$ & $\begin{array}{ll}11 & 0 \\
10 & 4 \\
11 & 4 \\
11 & 0 \\
11 & 0 \\
11 & .1 \\
10.7 \\
10.4 \\
10.7 \\
11.4\end{array}$ & $\begin{array}{l}11.7 \\
11.7 \\
117 \\
12.1 \\
12.1 \\
12.0 \\
12.3 \\
12.2 \\
12.3 \\
12.2\end{array}$ & 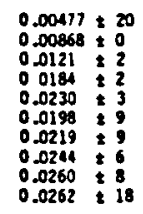 & $\begin{array}{l}1.98 \\
1.98 \\
1.98 \\
1.98 \\
1.98 \\
198 \\
1198 \\
1.98 \\
1.98 \\
1.98\end{array}$ & $\begin{array}{l}890 \\
890 \\
890 \\
8.90 \\
890 \\
8.90 \\
890 \\
890 \\
8.90 \\
890\end{array}$ & $\begin{array}{l}1.002 \\
1.002 \\
1.002 \\
1.002 \\
1.002 \\
1.000 \\
1.000 \\
1.000 \\
1.000 \\
1.000\end{array}$ & $\begin{array}{l}1.046 \\
1.046 \\
1.046 \\
1.046 \\
1.046 \\
1.007 \\
1.007 \\
1.007 \\
1.007 \\
1.007\end{array}$ & $\begin{array}{rl}42 & 8 \\
57 & 7 \\
71.0 \\
215 & 1 \\
166 & 7 \\
136 & 9 \\
172 & 5 \\
211.6 & .6 \\
224 & 1 \\
329 & 7\end{array}$ & $\begin{array}{r}536 \\
924 \\
1167 \\
1075 \\
917 \\
915 \\
723 \\
594 \\
568 \\
324\end{array}$ & $\begin{array}{l}59.9 \\
39.6 \\
60.2 \\
60.1 \\
60.9 \\
59.3 \\
59.2 \\
61.2 \\
62.4 \\
63.5\end{array}$ \\
\hline $\begin{array}{l}15 \\
46 \\
47 \\
40 \\
49 \\
50 \\
51 \\
52 \\
53\end{array}$ & 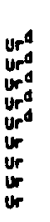 & $\begin{array}{l}\text { Mrse } \\
\text { Murse } \\
\text { Marse } \\
\text { Marse } \\
\text { Merse } \\
\text { Mars } \\
\text { Mors } \\
\text { Mors } \\
\text { Wers }\end{array}$ & 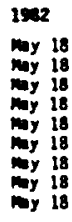 & $\begin{array}{l}Q-1(49) \\
Q-2(49) \\
Q-4(49) 9 \\
Q-5(49)^{9} \\
Q-6(49) \\
Q-1(49)^{n} \\
Q-5(49)^{n} \\
\theta-1(33) \\
\sigma-2(33)\end{array}$ & $\begin{array}{ll}11 & .7 \\
11 & 8 \\
11 & 8 \\
12 & 0 \\
11 & 8 \\
12 & 0 \\
12 & 0 \\
11 & 8 \\
11.7\end{array}$ & $\begin{array}{ll}13 & .0 \\
13 & 0 \\
12 & .0 \\
12 & 0 \\
14 & 0 \\
13.9 \\
13 & .8 \\
12 & 0 \\
11.9\end{array}$ & $\begin{array}{r}9.38: 10^{-4} \\
3.59: 10^{-3} \\
956=10^{-3} \\
1.01: 10^{-2} \\
1.04: 10^{-2} \\
1.05: 10^{-2} \\
1.71=10^{-2} \\
1.02: 10^{-3} \\
372: 10^{-3}\end{array}$ & $\begin{array}{l}1.97 \\
1.97 \\
1.91 \\
1.97 \\
199 \\
1.97 \\
1997 \\
1.97 \\
197\end{array}$ & $\begin{array}{l}5.93 \\
5.93 \\
5.93 \\
5.93 \\
5.93 \\
5.93 \\
59.93 \\
59.93 \\
593\end{array}$ & $\begin{array}{l}1.000 \\
1.000 \\
1.000 \\
1.000 \\
1.000 \\
1.000 \\
1.000 \\
1.005 \\
1.005\end{array}$ & $\begin{array}{l}1.020 \\
1.020 \\
1.020 \\
1.020 \\
1.020 \\
1.020 \\
1.020 \\
1.043 \\
1.043\end{array}$ & $\begin{array}{rl}42 & 8 \\
57 & 7 \\
115 & 2 \\
166 & 8 \\
101.2 \\
115.8 \\
168.8 \\
42.8 \\
57.8\end{array}$ & $\begin{array}{r}583 \\
934 \\
990 \\
803 \\
1062 \\
878 \\
733 \\
625 \\
958\end{array}$ & $\begin{array}{l}60.8 \\
59.5 \\
58.4 \\
61.7 \\
58.6 \\
55.7 \\
59.2 \\
61.7 \\
602\end{array}$ \\
\hline $\begin{array}{l}54 \\
55 \\
56\end{array}$ & $\begin{array}{l}u r^{d} \\
u r^{d} \\
u r\end{array}$ & $\begin{array}{l}\text { Mars } \\
\text { Mers } \\
\text { Mars }\end{array}$ & $\begin{array}{l}\log 29 \\
\text { Aug } 29 \\
\text { Aug } 29\end{array}$ & $\begin{array}{l}Q-1(49) \\
0-2(49) \\
Q-6(49)\end{array}$ & $\begin{array}{l}140 \\
140 \\
140\end{array}$ & $\begin{array}{l}15.0 \\
15.0 \\
15 \text {. }\end{array}$ & $\begin{array}{l}211=10^{-3} \\
589: 10^{-3} \\
2.62=10^{-2}\end{array}$ & $\begin{array}{l}1.86 \\
1.86 \\
1.86\end{array}$ & $\begin{array}{l}3.20 \\
3.20 \\
3.20\end{array}$ & $\begin{array}{l}1.000 \\
1.000 \\
1.000\end{array}$ & $\begin{array}{l}1.006 \\
1.006 \\
1.006\end{array}$ & $\begin{array}{r}42.8 \\
57 \% \\
101.2\end{array}$ & $\begin{array}{l}494 \\
780 \\
789\end{array}$ & $\begin{array}{l}60.4 \\
58.3 \\
54.8\end{array}$ \\
\hline $\begin{array}{l}57 \\
58 \\
59 \\
60\end{array}$ & $\begin{array}{l}\text { ur } \\
\text { ur } \\
\text { ur } \\
\text { tr }\end{array}$ & $\begin{array}{l}\text { Mers } \\
\text { mars } \\
\text { mars } \\
\text { mars }\end{array}$ & $\begin{array}{ll}\operatorname{sep} & 2 \\
\operatorname{sep} & 2 \\
\operatorname{sep} & 2 \\
\operatorname{sep} & 2\end{array}$ & $\begin{array}{l}Q-1(49) \\
Q-2(49) \\
Q-4(49) 9 \\
R-5(49)^{9}\end{array}$ & $\begin{array}{ll}12 & 0 \\
12 & 0 \\
12 & 0 \\
12 & 0\end{array}$ & $\begin{array}{ll}12 & .0 \\
12 & 0 \\
12 & -0 \\
12 & 0\end{array}$ & $\begin{array}{l}245=10^{-3} \\
3.45: 10^{-1} \\
244: 10^{-2} \\
4.02=10^{-2}\end{array}$ & $\begin{array}{l}1.6 \\
186 \\
186 \\
186\end{array}$ & $\begin{array}{ll}3 & 15 \\
3 & 15 \\
3 & 15 \\
3 & 15\end{array}$ & $\begin{array}{l}1.000 \\
1.000 \\
1.000 \\
1.000\end{array}$ & $\begin{array}{l}1.005 \\
1.005 \\
1.005 \\
1.005\end{array}$ & $\begin{array}{r}12.8 \\
57.8 \\
115.2 \\
166.8\end{array}$ & $\begin{array}{l}437 \\
742 \\
719 \\
588\end{array}$ & $\begin{array}{ll}59 & 1 \\
54 & 3 \\
53 & 7 \\
55 & 7\end{array}$ \\
\hline $\begin{array}{l}61 \\
62 \\
63 \\
64 \\
65 \\
66 \\
67 \\
68\end{array}$ & 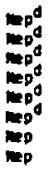 & $\begin{array}{l}\text { ur } \\
u r . \\
u r e \\
u r e \\
u r e \\
u r \\
u r \\
u r\end{array}$ & 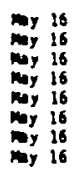 & $\begin{array}{l}Q-1(49) \\
Q-2(19) \\
2-149)^{n} \\
Q-5.49)^{n} \\
E-6(49) \\
E-1(33) \\
Q-2(33) \\
R-6(33)\end{array}$ & $\begin{array}{l}? \\
? \\
7 \\
? \\
? \\
?\end{array}$ & $\begin{array}{l}3 \\
3 \\
? \\
y \\
? \\
?\end{array}$ & 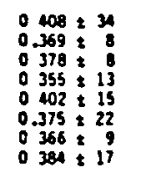 & $\begin{array}{ll}1 & 15 \\
1 & 15 \\
1 & 15 \\
1 & 15 \\
1 & 15 \\
1 & 15 \\
1 & 15 \\
1 & 15\end{array}$ & $\begin{array}{l}1.97 \\
197 \\
197 \\
197 \\
197 \\
197 \\
197 \\
1.97\end{array}$ & $\begin{array}{l}1.000 \\
1.000 \\
1.000 \\
1.000 \\
1.000 \\
1.00 \\
1.000 \\
1.000\end{array}$ & $\begin{array}{l}1.000 \\
1.000 \\
1.000 \\
1.000 \\
1.000 \\
1.000 \\
1.000 \\
1.000\end{array}$ & $\begin{array}{rl}41 & 8 \\
56 & 1 \\
113 & 3 \\
164 & 7 \\
101 & 1 \\
41.8 \\
58.2 \\
99 & 7\end{array}$ & $\begin{array}{l}184 \\
347 \\
361 \\
269 \\
399 \\
168 \\
345 \\
382\end{array}$ & $\begin{array}{l}60.8 \\
61.0 \\
59.8 \\
60.4 \\
60.8 \\
59.8 \\
609 \\
59\end{array}$ \\
\hline $\begin{array}{l}69 \\
70 \\
71 \\
72\end{array}$ & 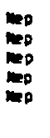 & $\begin{array}{l}\text { Ure } \\
\text { Ure } \\
\text { ure } \\
\text { Ure } \\
\text { ure }\end{array}$ & 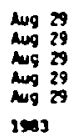 & $\begin{array}{l}E-1(49) \\
E=2.49 ! \\
E-4,49,5 \\
E-5 i 49) 5 \\
R-6(49)\end{array}$ & $\begin{array}{ll}11 & 0 \\
11 & 0 \\
11 & 0 \\
11 & 0 \\
11 & 0\end{array}$ & $\begin{array}{ll}11 & 0 \\
14 & 0 \\
14 & 0 \\
14 & 0 \\
14 & 0\end{array}$ & $\begin{array}{ll}0 & 120 \\
0 & 406 \\
0 & 111 \\
0 & 386\end{array}$ & $\begin{array}{cc}1 & 14 \\
1 & 14 \\
1 & 14 \\
1 & 14 \\
1 & 14\end{array}$ & $\begin{array}{l}186 \\
186 \\
1.86 \\
1.86 \\
1.86\end{array}$ & $\begin{array}{l}1.000 \\
1.000 \\
1.00 \\
1.000 \\
1.000\end{array}$ & $\begin{array}{l}1.000 \\
1.000 \\
1.00 \\
1.000 \\
1.000\end{array}$ & $\begin{array}{rl}41.3 \\
58.5 \\
113.8 \\
165 & 3 \\
101.5\end{array}$ & $\begin{array}{l}191 \\
338 \\
328 \\
265 \\
324\end{array}$ & $\begin{array}{l}60 ? \\
60 ? \\
57 ? \\
609 \\
56.6\end{array}$ \\
\hline $\begin{array}{l}74 \\
75 \\
76\end{array}$ & $\begin{array}{l}\text { ur } \\
\text { ur } \\
\mathbf{u r} \\
\mathbf{u r}\end{array}$ & $\begin{array}{l}\text { Jup } \\
\text { Jup } \\
\text { Jud } \\
\text { Jup }\end{array}$ & $\begin{array}{l}\text { Jun } \\
\text { Jun } \\
\text { Jun } \\
\text { Jun } 4\end{array}$ & $\begin{array}{l}M 1-1(73) \\
M 1-3(73) \\
m-6 ! 73 \\
m 1-7(73)\end{array}$ & $\begin{array}{l}13.0 \\
130 \\
120 \\
120\end{array}$ & $\begin{array}{ll}12 & 0 \\
12 & 0 \\
11 & 0 \\
11 & 0\end{array}$ & $\begin{array}{l}\infty 0177 \\
\infty 0205=6 \\
00215=2 \\
\infty 0272 \geq 2\end{array}$ & $\begin{array}{l}1 \% \\
196 \\
1 \% \\
1 \%\end{array}$ & $\begin{array}{ll}21 & 89 \\
21 & 89 \\
21 & -99 \\
2 i & 89\end{array}$ & $\begin{array}{l}1000 \\
+000 \\
1.000 \\
1.000\end{array}$ & $\begin{array}{ll}1 & 127 \\
1 & 127 \\
1 & 127 \\
1 & 12\end{array}$ & $\begin{array}{l}1059 \\
137.2 \\
19.2 \\
198.2\end{array}$ & $\begin{array}{r}1017 \\
798 \\
618 \\
590\end{array}$ & $\begin{array}{ll}502 & 2 \\
56 & 3 \\
50 & 7 \\
50\end{array}$ \\
\hline
\end{tabular}

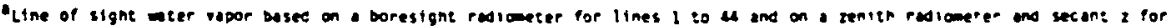

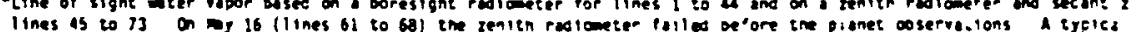
zenien viliu as used to est teate the boresignt ialue

- The orrors in the leest signtficant aigits are snow in cases mere repeatec easurments pere :tec statistical error andists

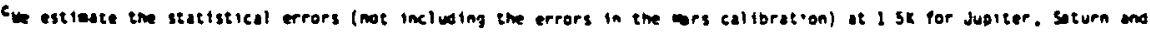
Uranus, ond 3 Sk for potume

tho coservitions of pl angt a meraged

"ho coservations of planet severages.

The short-wevelengen blocting fllter as beflon

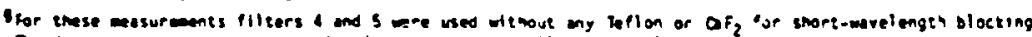

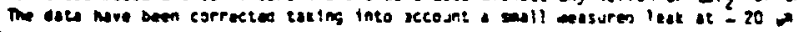

"Te wor:-wrelengt: ocking filter a, $\mathrm{OF}_{2}$ 
BRIGITMESS TEMPEDATURE $S^{2}$

(Summary of Cata from Tades $i i, I I i$, and IV)

\begin{tabular}{|c|c|c|c|c|c|c|c|c|c|}
\hline \multirow[t]{2}{*}{ Line } & \multicolumn{2}{|c|}{ Jupiter } & \multicolumn{2}{|c|}{ Saturn } & \multicolumn{2}{|c|}{ Uranus } & \multicolumn{3}{|c|}{ Neptune } \\
\hline & $\stackrel{\lambda}{(\mu m)}$ & $\begin{array}{l}\text { Temp } \\
(K)\end{array}$ & $\stackrel{\lambda}{\left({ }^{m} \mathrm{~m}\right)}$ & $\begin{array}{l}\text { Temp } \\
\text { (K) }\end{array}$ & $\stackrel{\lambda}{\left(u^{m}\right)}$ & $\begin{array}{l}\text { Temp } \\
(K)\end{array}$ & $\left(\stackrel{\lambda}{\nu^{m}}\right)$ & & $\begin{array}{l}\text { Temp } \\
\text { (K) }\end{array}$ \\
\hline 1 & 38.7 & 134.0 & 40.2 & $97.5 \pm 1.7^{b}$ & 42.8 & $60.3 \pm 0.7^{c}$ & 41.8 & 60.6 & $\pm 0.5^{c}$ \\
\hline 2 & 55.1 & 138.5 & 56.2 & $100.5 \pm 1.2^{b}$ & 57.7 & $59.2 \pm 0.7^{c}$ & 58.1 & 60.9 & $\pm 0.1^{c}$ \\
\hline 3 & 62.6 & 129.0 & 65.4 & $103.7 \pm 0.2^{b}$ & 74.0 & 60.2 & 100.8 & 58.9 & $\pm 2.1^{c}$ \\
\hline$\perp$ & 109.4 & 131.5 & 99.4 & 97.3 & 102.8 & $57.2 \pm 2.1^{b}$ & 113.4 & 58.9 & $\pm 1.3^{b}$ \\
\hline 5 & 135.4 & 128.1 & 102.6 & 99.3 & 115.3 & $57.0 \pm 2.8^{b}$ & 165.0 & 60.7 & $\pm 0.4^{b}$ \\
\hline 6 & 168.0 & $118.4 \pm 0.6^{b}$ & 110.8 & $102.9 \pm 1.6^{b}$ & 137.0 & $57.8 \pm 2.1^{b}$ & & & \\
\hline 7 & 204.0 & 132.7 & 135.5 & $98.8 \pm 1.7^{b}$ & 167.3 & $59.4 \pm 2.7^{b}$ & & & \\
\hline 8 & 221.8 & 133.6 & 148.6 & 99.9 & 172.5 & 59.2 & & & \\
\hline 9 & & & & & 191.1 & 58.7 & & & \\
\hline iv & & & & & 198.2 & 58.7 & & & \\
\hline 11 & 328.6 & 143.7 & 168.6 & $97.2 \pm 3.3^{b}$ & 211.6 & 61.2 & & & \\
\hline 12 & & & 205.2 & $97.2 \pm 1.3^{b}$ & 224.11 & 62.4 & & & \\
\hline 13 & & & 222.2 & 94.1 & 329.7 & 63.5 & & & \\
\hline 14 & & & 331.6 & $108.4 \pm 2.1^{b}$ & & & & & \\
\hline 15 & 353 & $165.5 \pm 2.5$ & 353 & $112.9 \pm 1.1$ & 353 & $62.4 \pm 2.3$ & 353 & 63.3 & \pm 2.5 \\
\hline 16 & 414 & $155.3 \pm 1.3$ & 414 & $119.2 \pm 1.2$ & 414 & $70.1 \pm 1.3$ & 414 & 67.9 & \pm 1.2 \\
\hline$i 7$ & 450 & $135 \pm 5$ & 450 & $112.3 \pm 3.2$ & 450 & $73 \pm 5$ & 450 & 68 & \pm 8 \\
\hline 18 & 517 & $149.9 \pm 2.6$ & 517 & $122.2 \pm 1.1$ & & & & & \\
\hline 19 & 664 & $167.1 \pm 2.1$ & 664 & $137 \pm 4$ & 664 & $88 \pm 6$ & 664 & 76 & \pm 9 \\
\hline 20 & 968 & \pm 10 & 968 & $134.5 \pm 3.2$ & 968 & $94.5 \pm 2.3$ & 968 & 103 & \pm 7 \\
\hline
\end{tabular}

a None of the errors shown in this table includes the uncertainty in the Mars calibration. Errors for IRTF data (lines 13-18) are computed as specified in Appendix D. Errors shown for KAO data (1ines 1-12) are standard deviations of two or more measurements from Table IV where the effective wavelengths fall within a range of $2 \mu^{\mathrm{m}}$. (See footnotes $b$ and concerning weighting.) The mean of the 19 errors for KAO data is $1.5 \mathrm{~K}$ (see discussion in text).

${ }^{b}$ Average of data for bandpass and low pass filters with values of $\lambda_{\text {eff }}$ within 2 un. Bandpass measurements are given twice the weight of low pass measurements.

"Averaye of data for $33^{\prime \prime}$ and $49^{\prime \prime}$ apertures ( $\lambda_{e f f}$ within $2 \mathrm{um}^{\mathrm{m}}$ ). To allow for possible guiding errors the 33" measurements are given half the weight of $49^{\prime \prime}$ measurements. 
TABLE VI

Effective temperature $T_{Q}$ and ratios, E/A, or

emitted to absorbed energy with assumed Bond Albedos

\begin{tabular}{lccccl} 
Planet & $T_{e}^{a}$ & $E / A^{a}$ & Bond Albedo & reference \\
\hline Jupiter & $126.8 \pm 44 \mathrm{~K}$ & $1.8 \pm 0.3$ & $0.343 \pm 0.032$ & Hanel et al, 1981 \\
Saturn & $934 \pm 33 \mathrm{~K}$ & $1.7 \pm 0.3$ & $0.342 \pm 0030$ & Hanel et al, 1983 \\
Uranus & $58.3 \pm 20 \mathrm{~K}$ & $1.2 \pm 0.2$ & $0.393 \pm 0.037$ & Lockwood et al, 1983 \\
Neptune & $60.3 \pm 20 \mathrm{~K}$ & $2.8 \pm 04$ & 029 & See text
\end{tabular}

a Errors reflect an assumed $15 \%$ absolute calibration error in flux. 


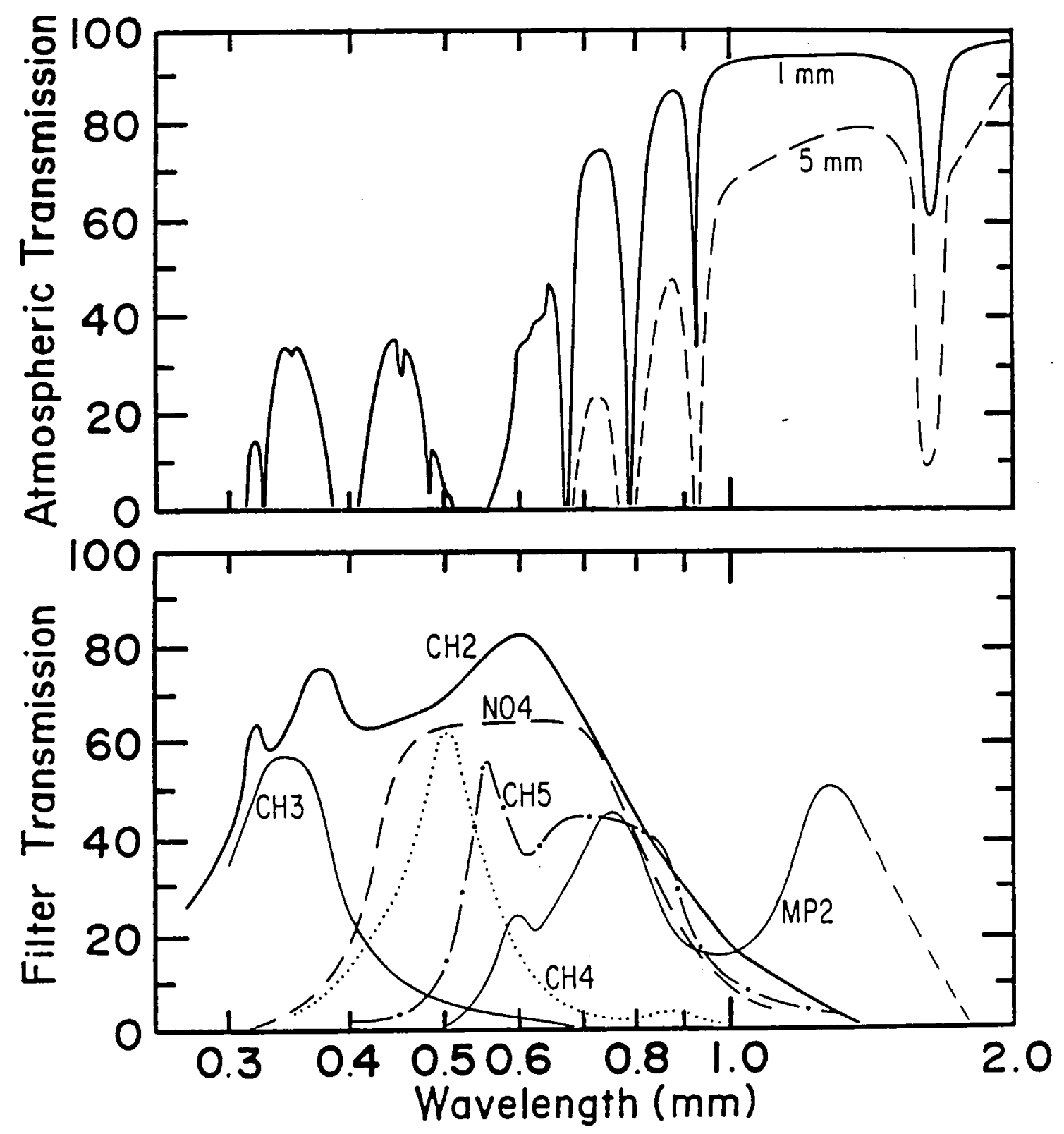

Fig. 1 


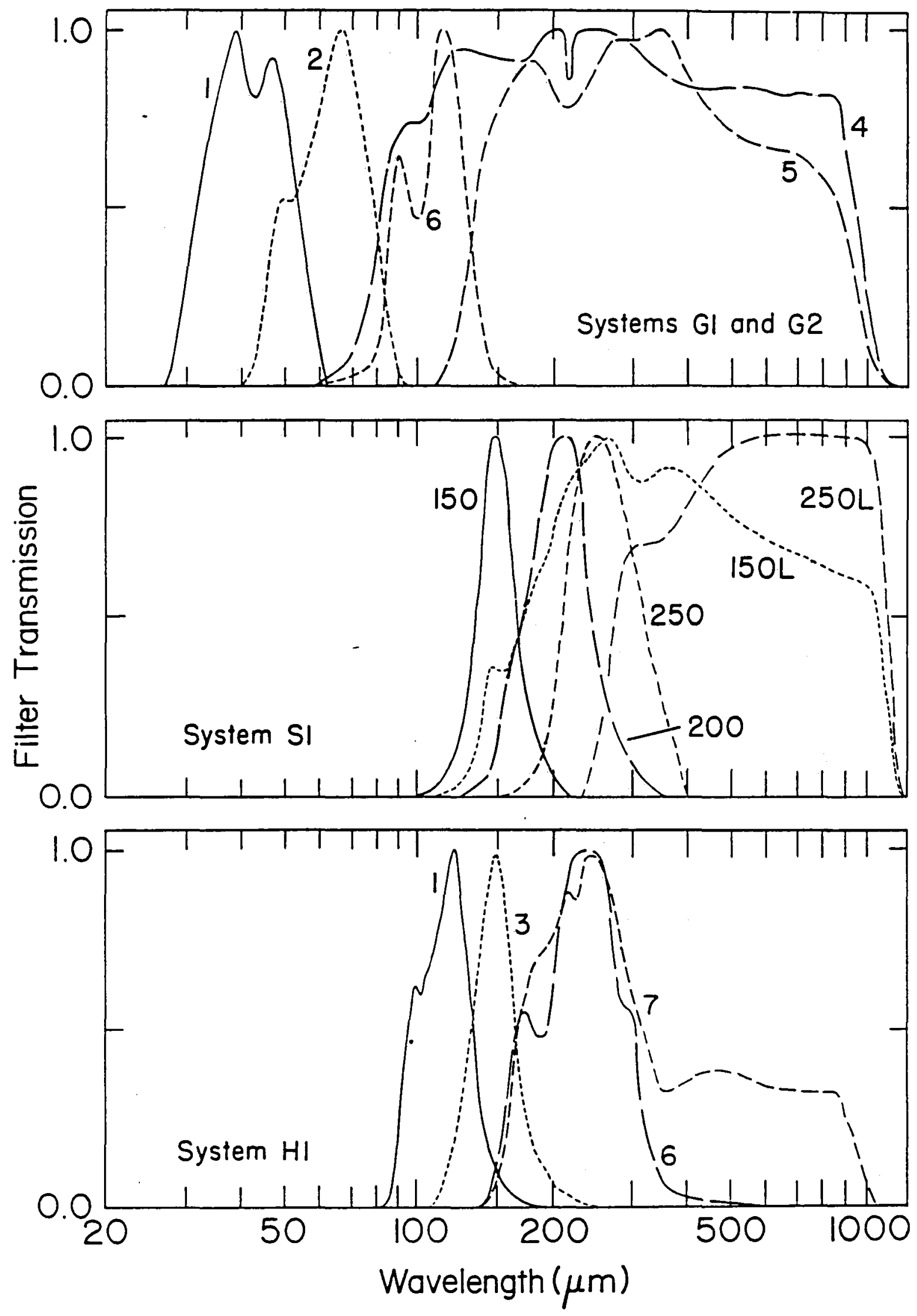

Fig. 2 


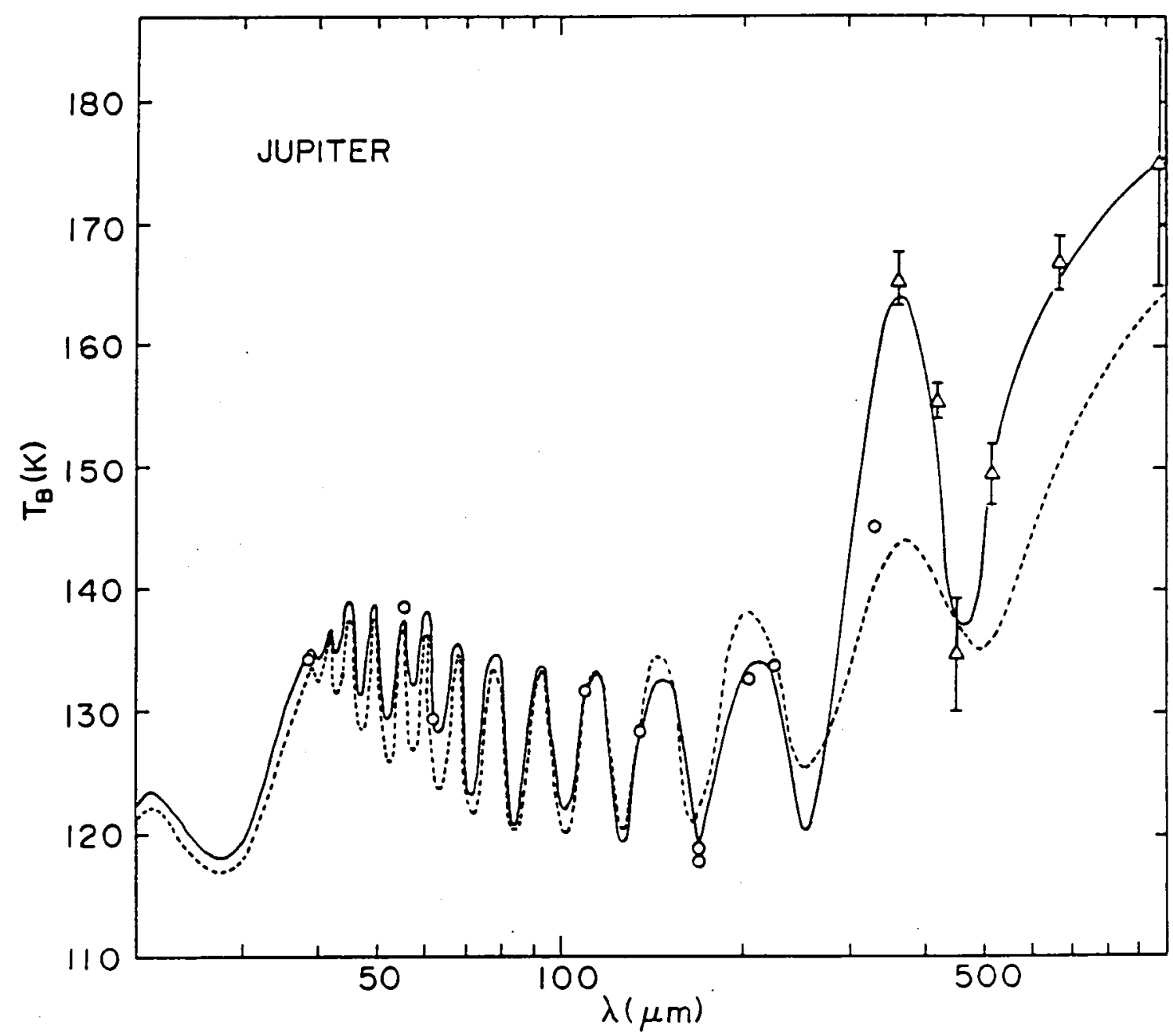

Fig. 3

55 


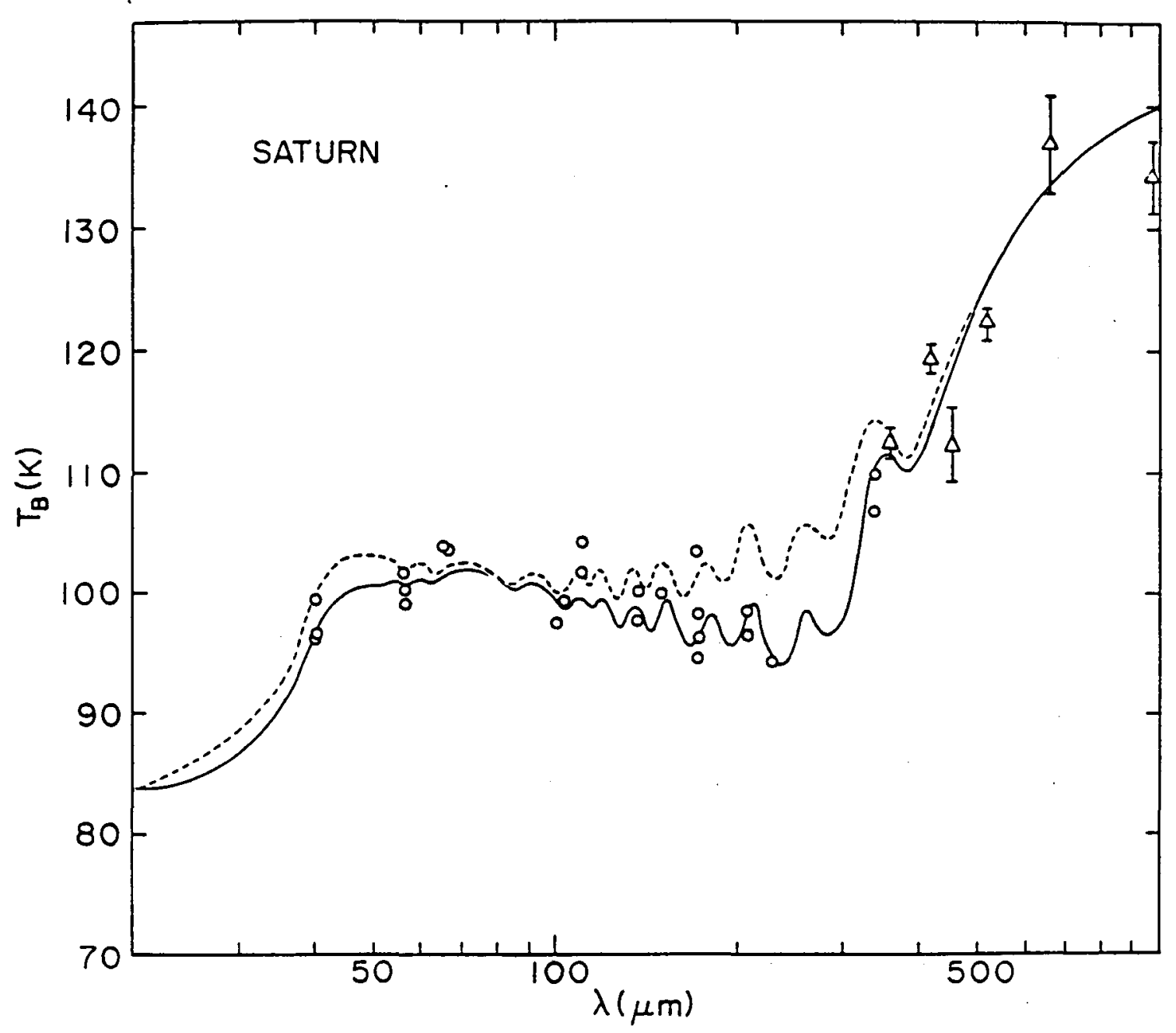

Fig. 4 


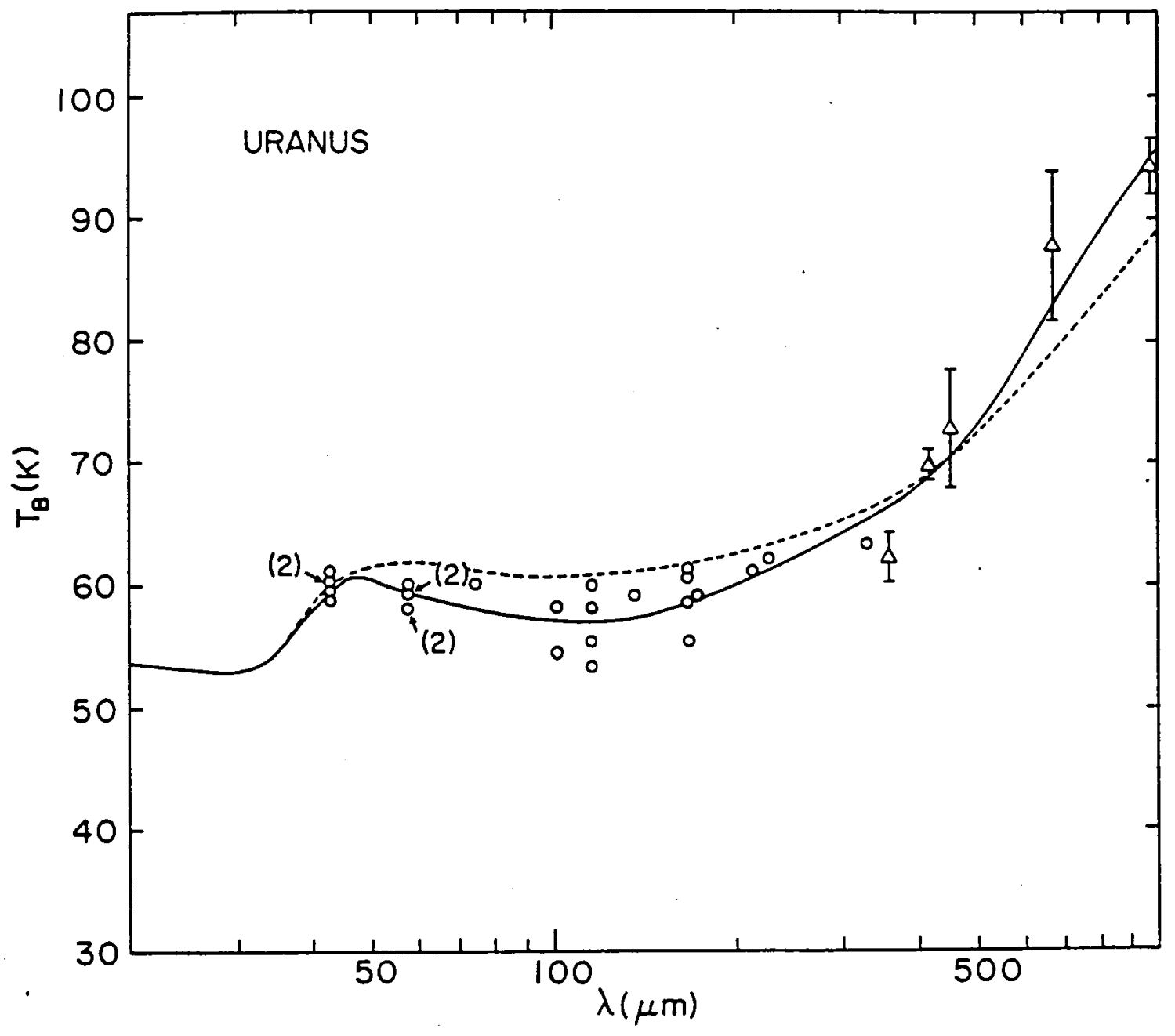

Fig. 5

57 


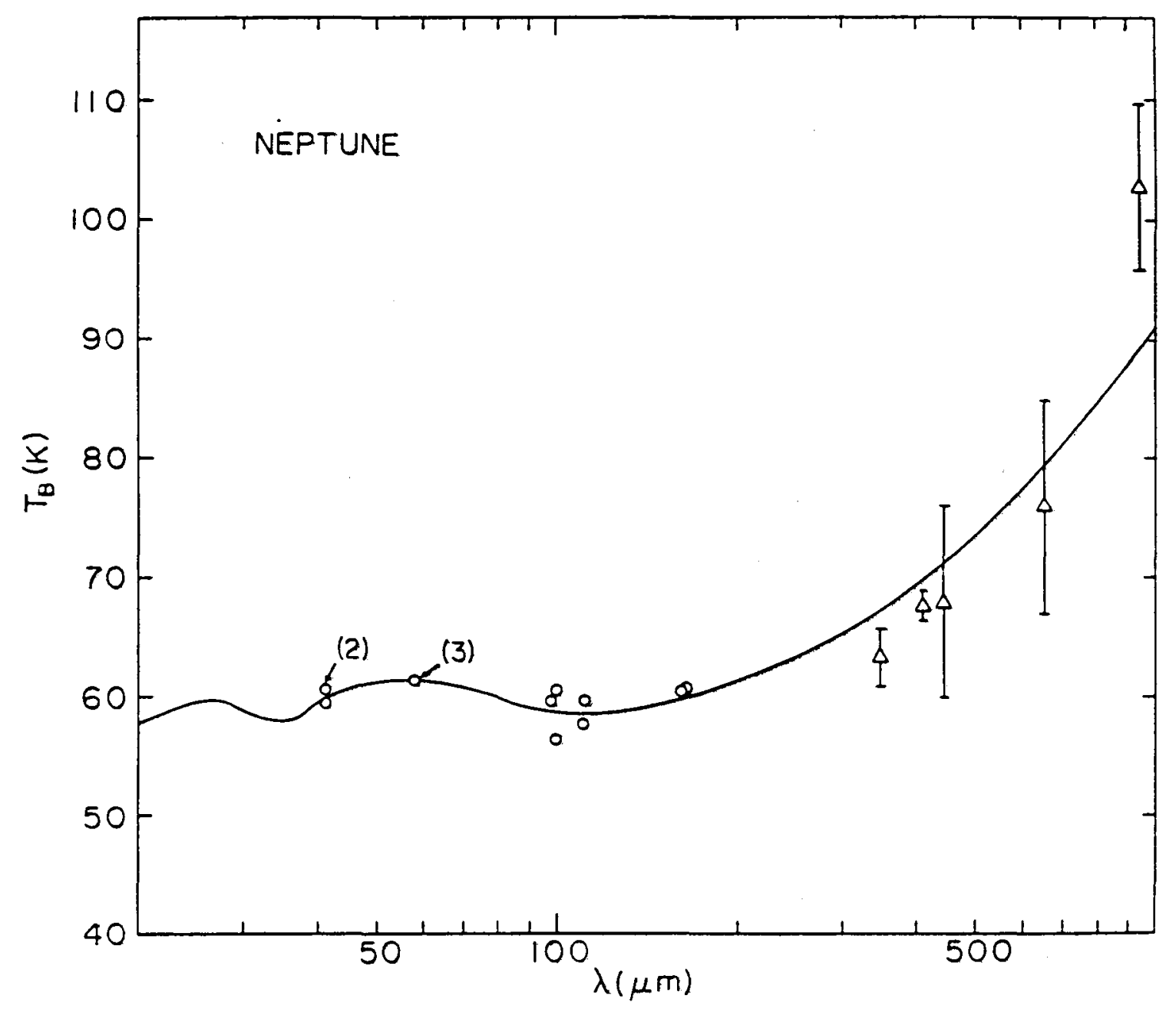

Fig. 6 


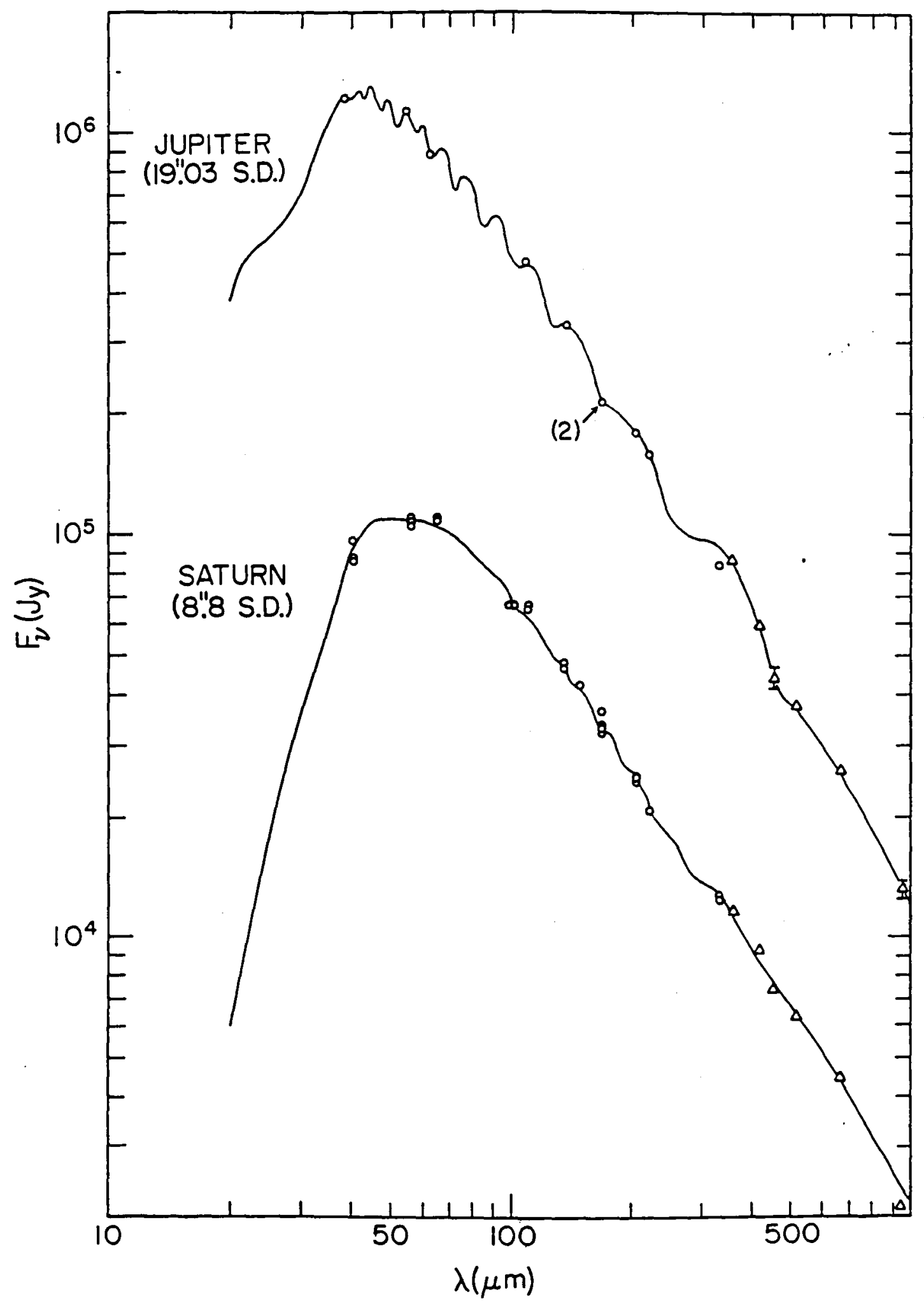

Fig. 7 


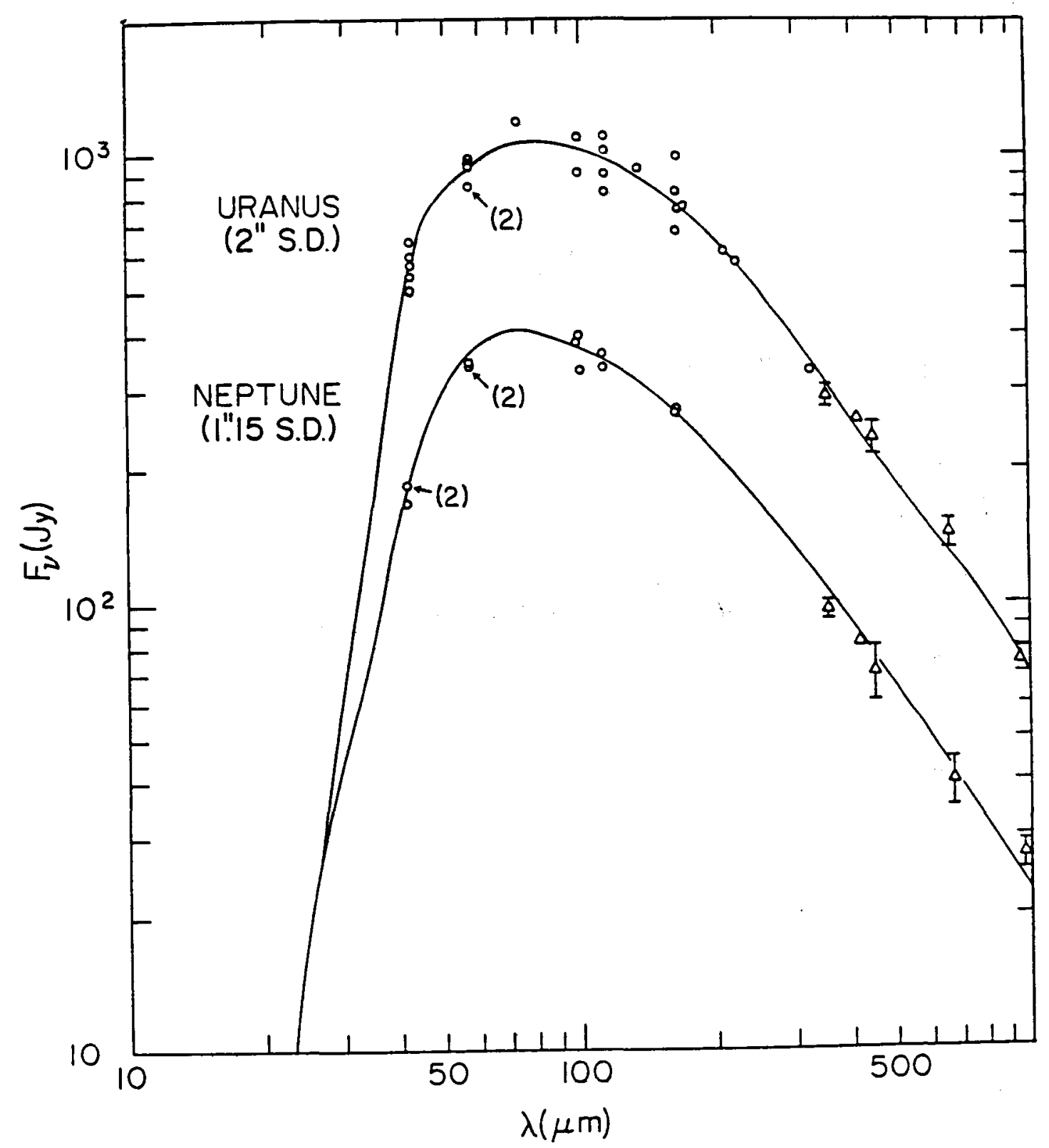

Fig. 8 


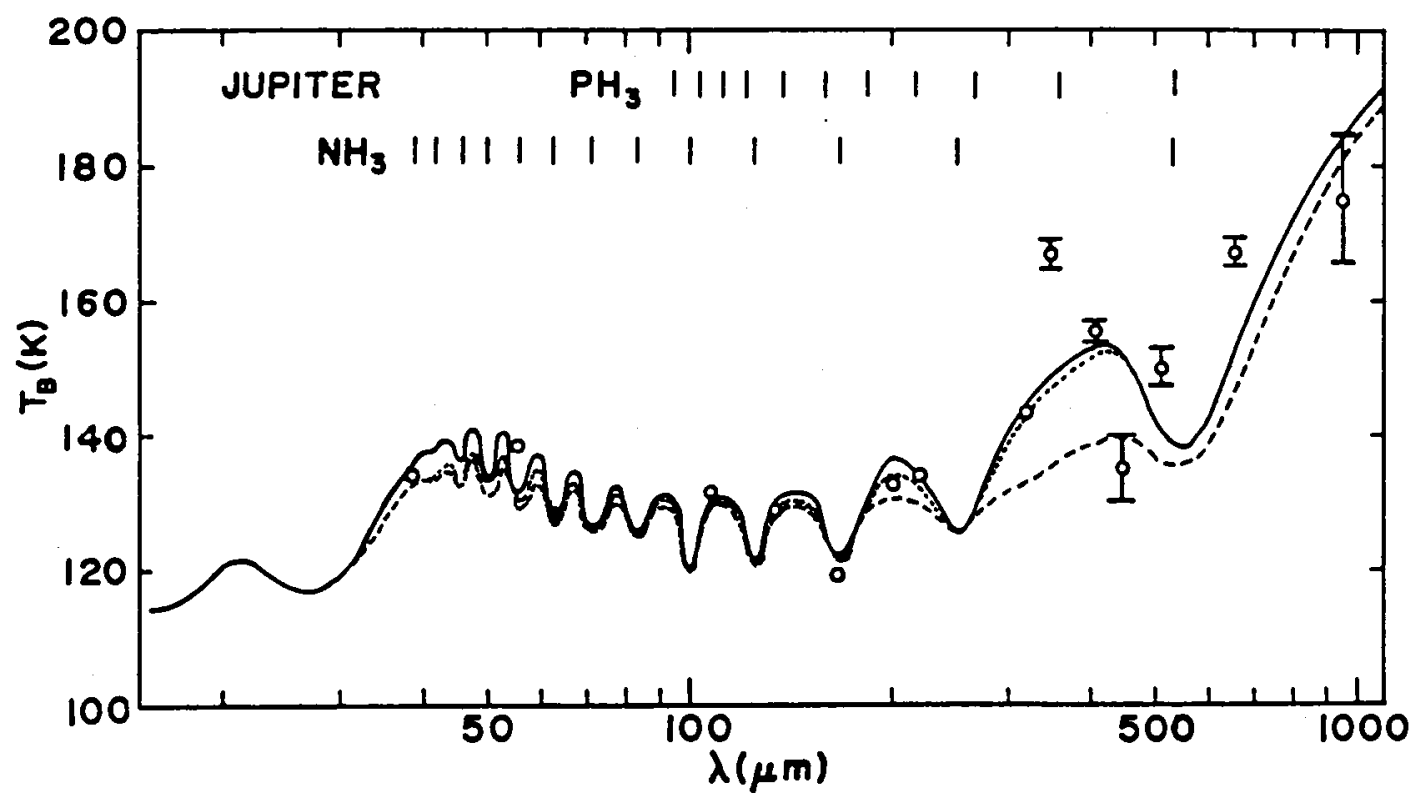

Fig. 9

61 


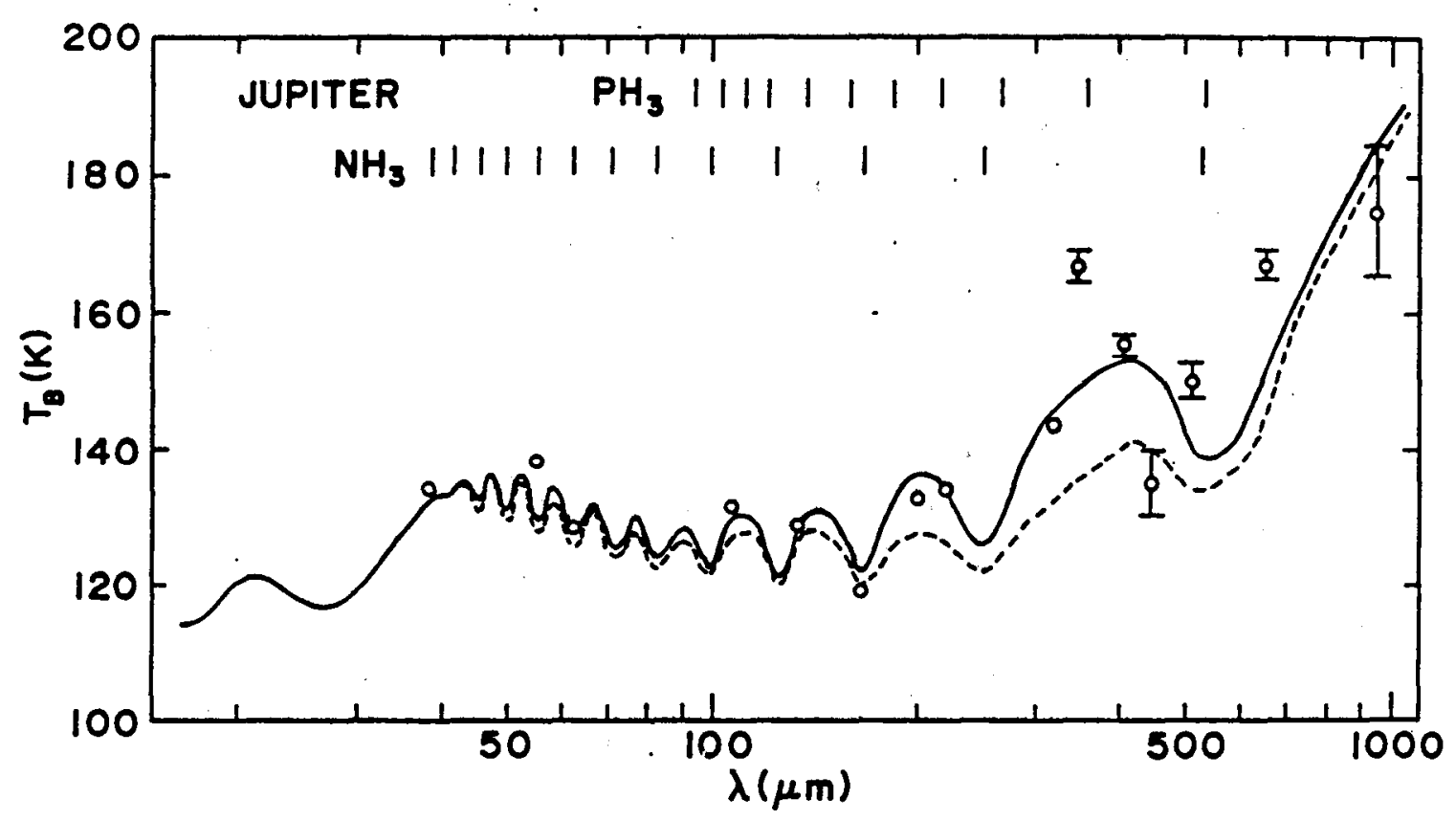

Fig. 10 


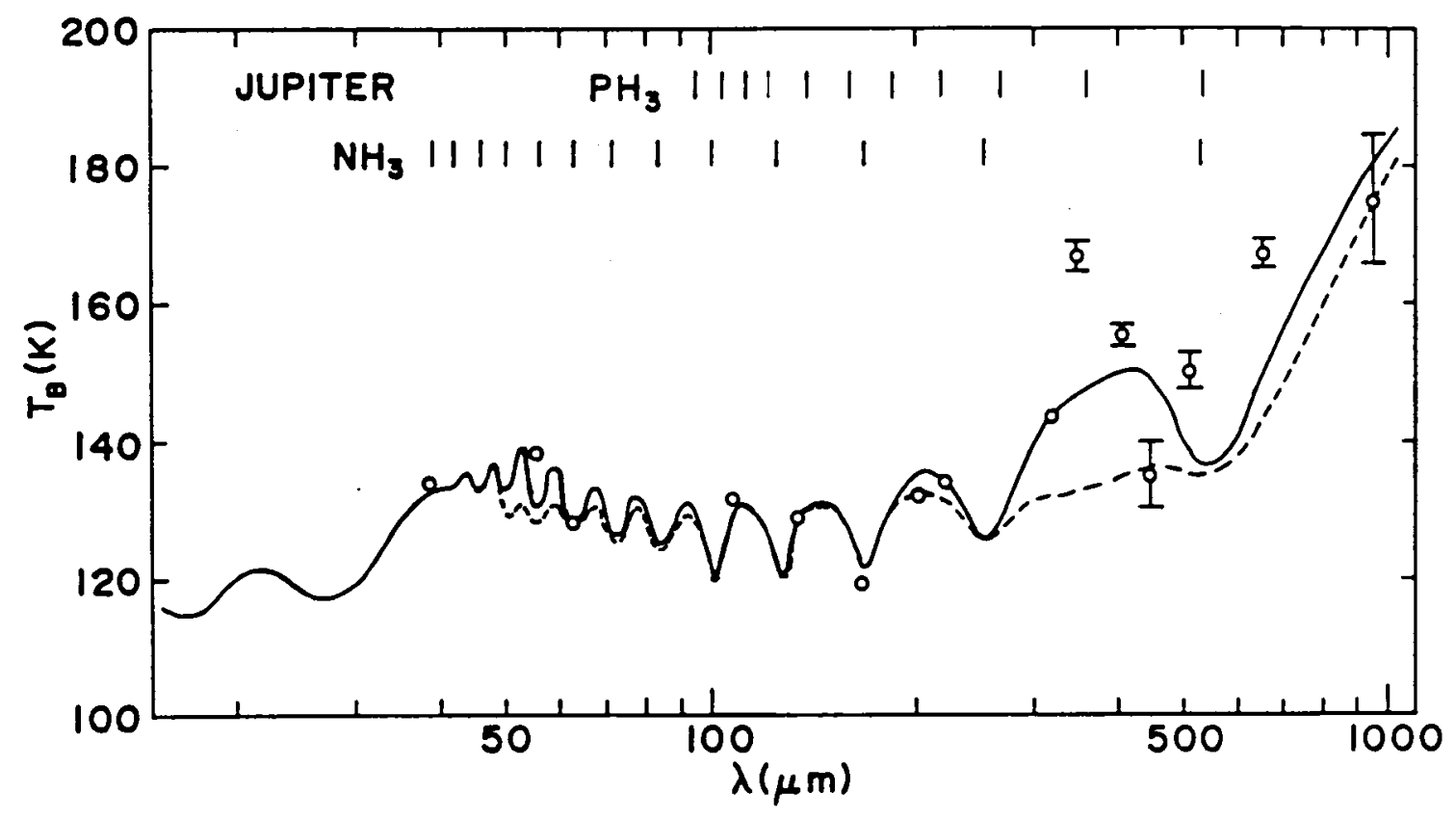

Fig. 11 


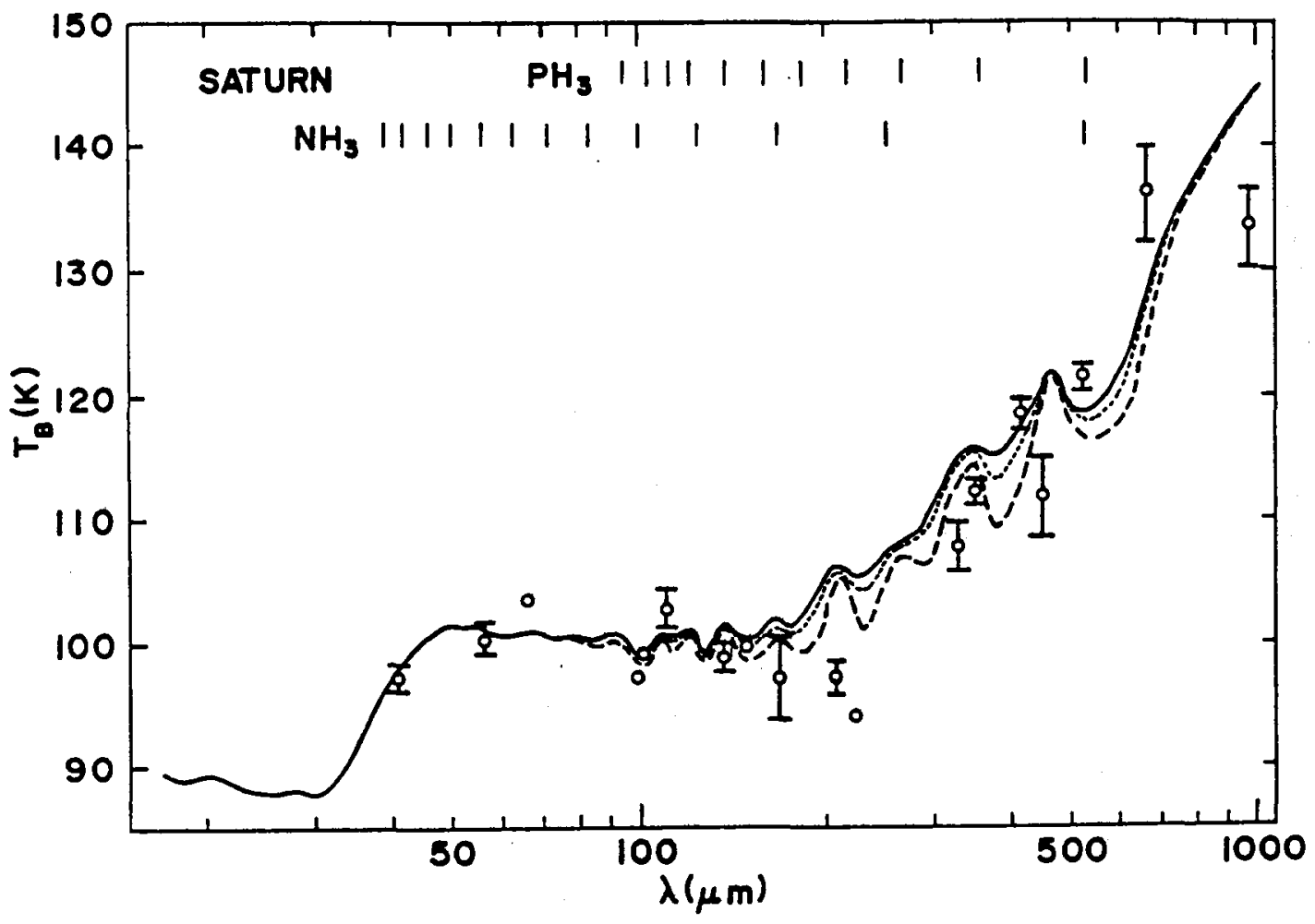

Fig. 12 


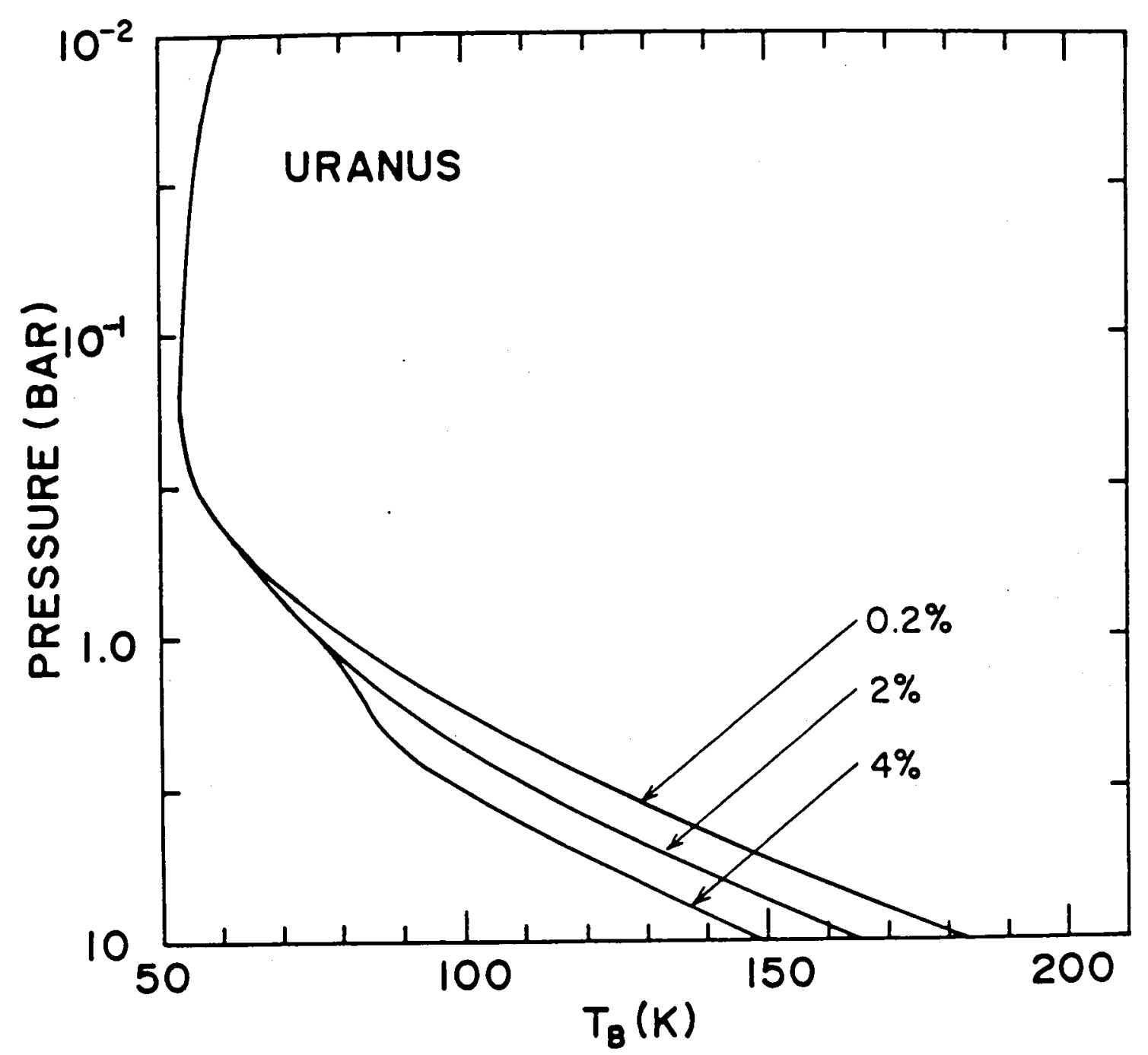

Fig. 13 


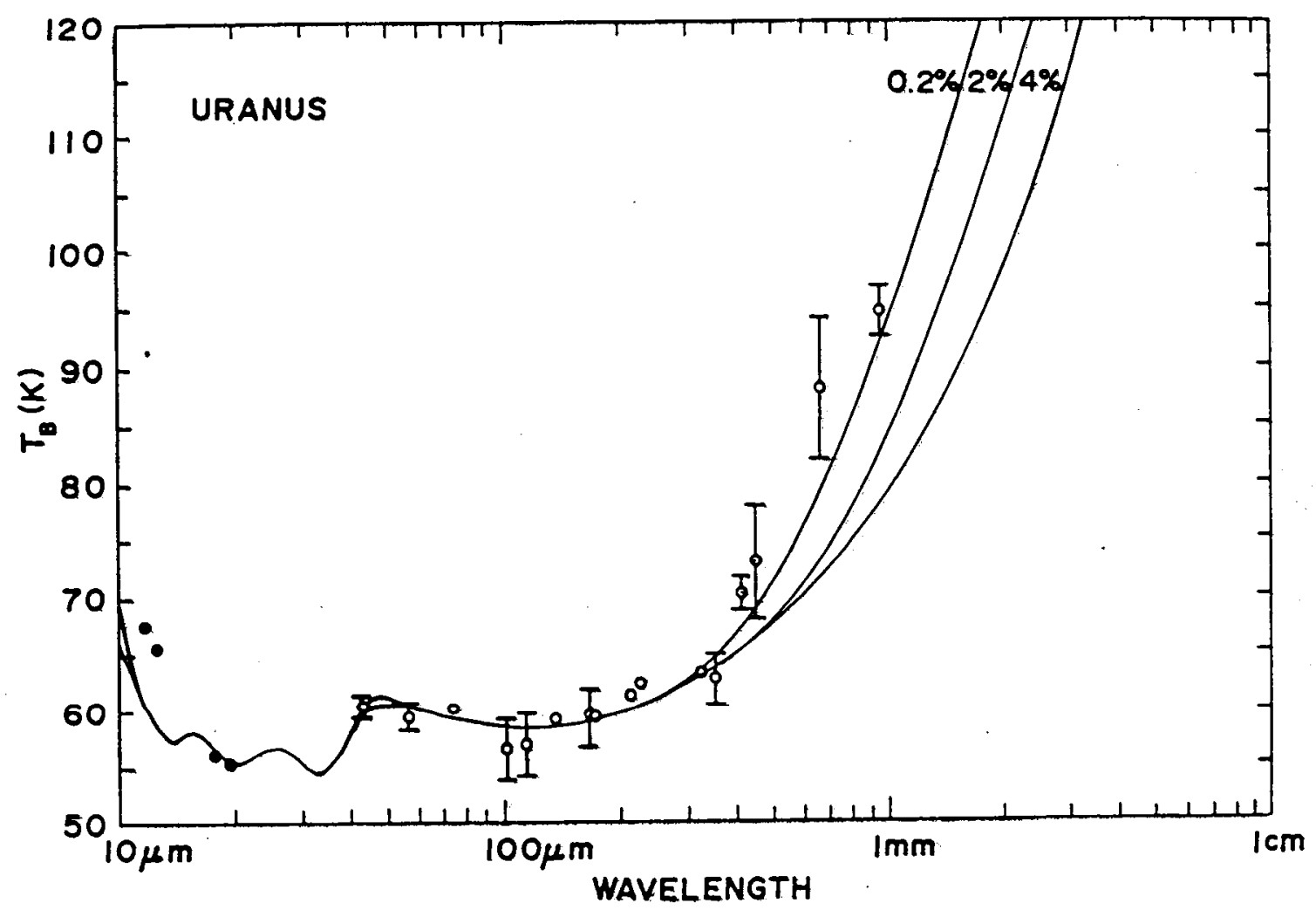

Fig. 14 


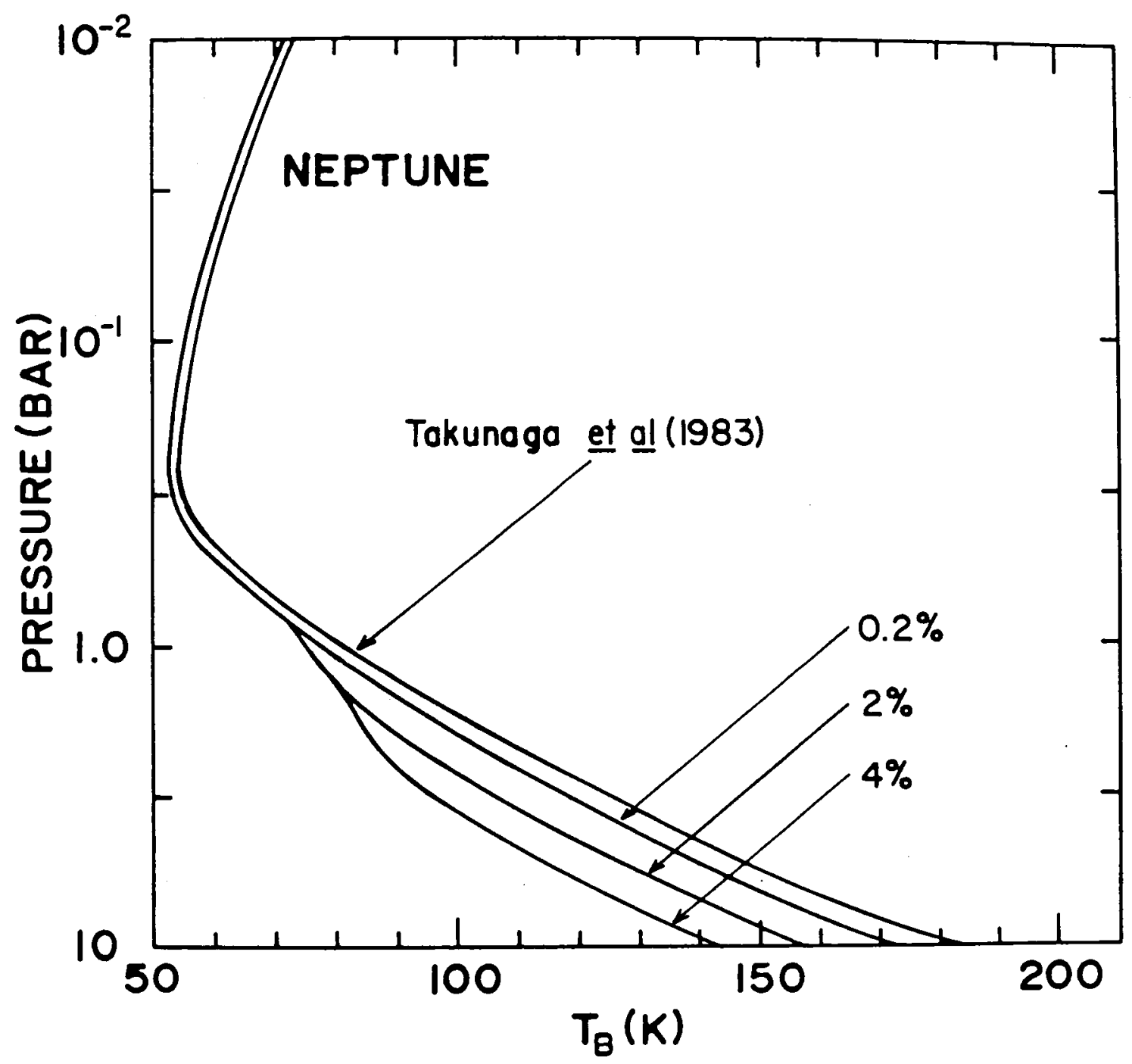

Fig. 15 


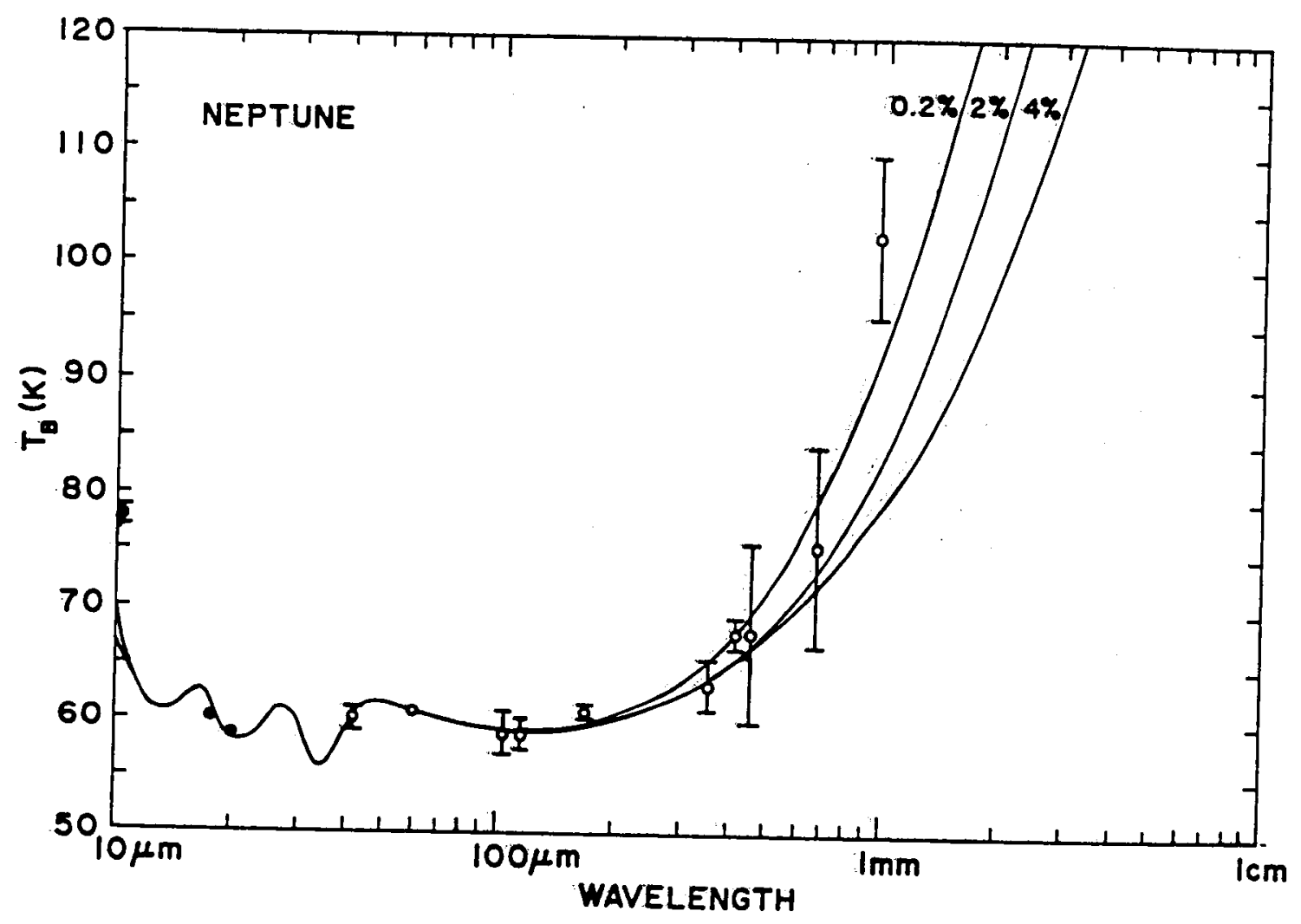

Fig. 16 


\section{TABLE I}

ASSUMED PLANETARY RADII (1-bar) a

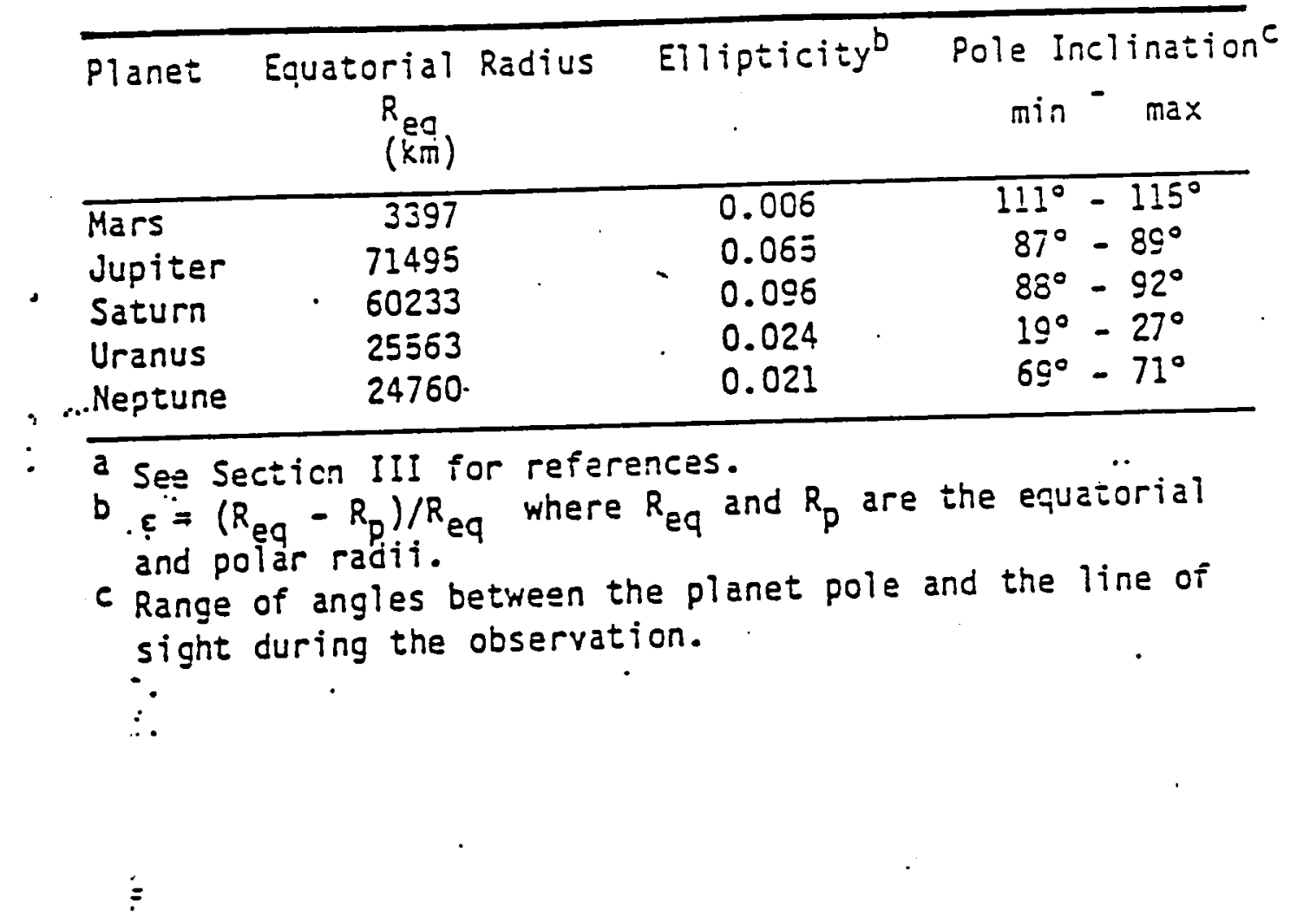


TABLE II

JOURNAL OF OBSERVATIONS: BROADBAND DATA

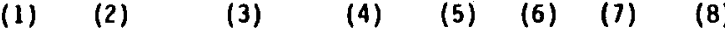

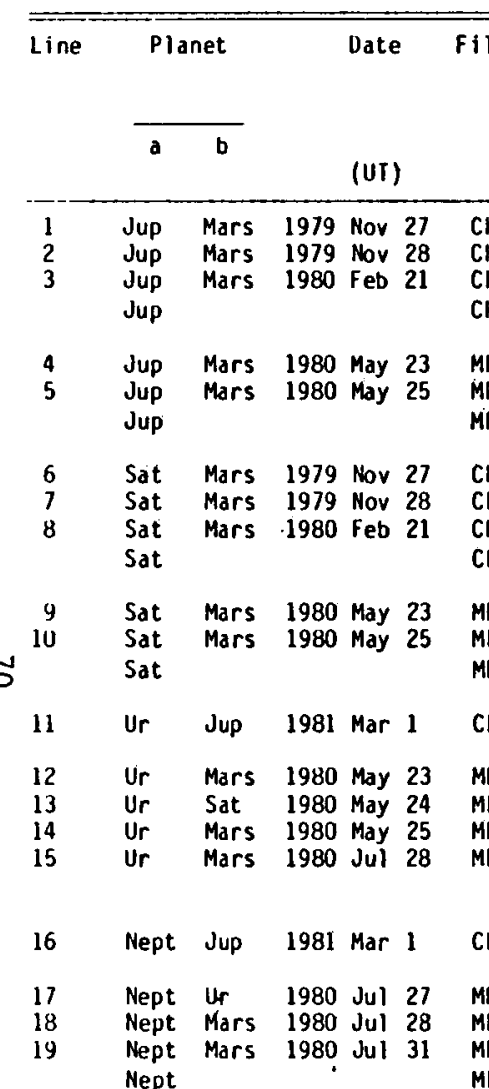

H2

(9)

(10) (11)

Siami-

(12) (13)

(14)

(15)

(16)

$\begin{array}{lcc}\begin{array}{l}\text { Finite disk } \\ \text { correctionc }\end{array} & \begin{array}{c}\text { Brightness } \\ \text { ratiod }\end{array} & \begin{array}{c}\text { Planet } \\ \text { temperature }\end{array}\end{array}$

$\mathrm{H}_{2} \mathrm{O} \quad \mathrm{H}_{2} \mathrm{O}$ diameter ${ }^{b}$ correction

$w(b)$

$\Delta(a) \Delta(a)$

$D(a) \quad D(b)$

$B(\mathrm{a}) / \mathrm{B}(\mathrm{b})$

$T(\mathrm{~b})^{\mathrm{e}}$

$T(\mathrm{~b})^{\mathrm{e}} \quad \mathrm{T}(\mathrm{a})^{\mathrm{t}}$

$\begin{array}{llllll}1.1 & 1.2 & 1.0 & 418 & 14.23 & \pm 0.18\end{array}$

$17.78 \quad 3.66$

1.185

$\begin{array}{lll}85 & 1.006 & 0.7\end{array}$

$710 \pm 0.009$

$\begin{array}{rrrrrr}1.4 & 1.4 & 1.2 & 428 & 13.97 & \pm 0.17 \\ 0.9 & 0.9 & 0.7 & 411 & 5.36 & \pm 0.38\end{array}$

$17.83 \quad 3.69$

$\begin{array}{llllll}4.5 & 4.4 & 2.7 & 952 & 19.34 & \pm 1.82 \\ 5.9 & 5.9 & 4.5 & 992 & 17.82 & \pm 1.16\end{array}$

\section{$\begin{array}{llllll}1.2 & 1.2 & 1.0 & 421 & 2.52 & \pm 0.03\end{array}$}

$\begin{array}{llllll}1.4 & 1.4 & 1.2 & 428 & 2.50 & \pm 0.04\end{array}$

$17.89 \quad 3.89$

$\begin{array}{ll}1.186 \\ .86 & 1.306\end{array}$

006

(K)

213

$155.9 \pm 1.8$ $\begin{array}{rl}152.8 \pm & \pm \\ 152.4 & 9.7\end{array}$ $\frac{152.4 \pm 9.7}{155.3 \pm 1.39}$

\section{$\begin{array}{llllll}3.4 & 4.4 & 2.7 & 936 & 3.33 & \pm 0.17\end{array}$}$$
\begin{aligned}
& 8.12 \\
& 9.27
\end{aligned}
$$

$\begin{array}{lllllll}8.12 & 3.66 & 1.032 & 1.006 & 0.525 \pm 0.006 & 213\end{array}$

$\begin{array}{lllllll}9.27 & \mathbf{6 . 8 6} & 1.031 & 1.009 & 0.526 \pm 0.009 & 213 \\ & & & 1.020 & 0.471 \pm 0.037 & 213.5\end{array}$

$\begin{array}{llllll}8.68 & 3.89 & 1.006 & 1.000 & 0.673 \pm 0.035 & 199\end{array}$

199

\section{$\begin{array}{llll}0.4 & 0.4 & 0.3 & 394\end{array}$ \\ $(4.047 \pm 0.062) 10^{-3}$}

1.8920

1.000

1.280

$\begin{array}{lllll}3.5 & 4.4 & 2.7 & 937 & 0.130 \pm 0.020\end{array}$

$\begin{array}{rrrr}6.8 & 8.5 & 5.3 & 1020\end{array}$

$0.130 \pm 0.020$
$0.038 \pm 0.002$

1.98

$3.89 \quad 1.000$

.280

$0.388+0.006$

$\begin{array}{llllll}1.98 & 3.83 & 1.000 & 1.000 & 0.722 \pm 0.038\end{array}$

$\begin{array}{rrrrr}8.4 & 8.4 & 6.4 & 1012 & 0.209 \pm 0.007\end{array}$

$\begin{array}{llll}3.83 & 1.000 & 1.000 & 0.483 \pm 0.041 \\ 2.76 & 1.000 & 1.000 & 0.436 \pm 0.014\end{array}$

$134.5 \pm 3.2$

203

$\begin{array}{llll}0.4 & 0.4 & 0.3 & 394\end{array}$

$(1.340 \pm 0.023) 10^{-3}$

$0.93 \quad 1.000$

$\begin{array}{lllll}5.8 & 6.2 & 4.3 & 995 & 0.352 \pm 0.050\end{array}$

$0.352 \pm 0.050$
$0.086 \pm 0.008$

$155.3 \pm 1.3$

$0.112 \pm 0.023$

$\begin{array}{lllll}1.15 & 1.91 & 1.000 & 1.000 & 0.971 \pm 0.138 \\ 1.14 & 2.76 & 1.000 & 1.000 & 0.504 \pm 0.047\end{array}$

$\begin{array}{llllll}1.14 & 2.76 & 1.000 & 1.000 & 0.504 \pm 0.047 & 203 \\ 1.14 & 2.73 & 1.000 & 1.000 & 0.642 \pm 0.133 & 203.5\end{array}$

$98.5 \pm 2.3$

203.5

$187.9 \pm 17.1$

$170.2 \pm 10.7$

$119.4 \pm 1.2$

$119.5 \pm 1.8$

$109.1 \pm 7.3$

$119.2 \pm 1.2^{9}$

$136.4 \pm 6.7$

$\frac{133.9 \pm 3.6}{134.5 \pm 3.2^{4}}$

$70.1 \pm 1.3$

$103.6 \pm 14.8$ $99.0 \pm 3.3$ $99.7 \pm 7.9$
$92.4 \pm 2.7$ $\frac{92.4 \pm 2.7}{94.5 \pm 2.39}$

$67.9 \pm 1.2$

$92.0 \pm 12.1$ $105.7 \pm 9.2$ $\overline{10} 3.0 \pm 7.29$

a) Wavelength corresponding to effective frequency as given in equation (2) of text, for water vapor $=\frac{1}{2}[w(a)+w(b)]$. See footnote $f$. b) Based on assumed radii shown in Table IV.

d) $B(a) / B(b)=[S(a) / S(b)][\phi(b) / \phi(a)]^{2}[D(a) / D(b)]$.

e) Mars temperatures based on Wright's model $(1980)$ assuming no wavelength dependence for $\lambda \geq 350$ um. Other temperatures fram table $V$.

f) For filters CH2 and MP2. T(a) is insensitive to $\alpha$ (colum 8 ) and hence to $w(a)$ and $w(b)$ (columns 5 and 6$)$.

9) Averaye of values for same planet and filter. 
TAOLE III

JOURNAL OF OBSERVATIONS: MARROHER BAND DATA

(1) $\div 21$

(3)

(4)

(5)

(6)

(7)

(8)

(9)

\begin{tabular}{|c|c|c|c|c|c|c|c|c|c|c|}
\hline \multirow[t]{2}{*}{ ine } & \multicolumn{2}{|c|}{ P!anet } & \multirow{2}{*}{\multicolumn{2}{|c|}{$\begin{array}{l}\text { Daze } \\
\text { (UT) }\end{array}$}} & \multirow{2}{*}{$\frac{\text { Fil ters }}{x}$} & \multirow{2}{*}{$\frac{s(a x) / s(a y)}{s(5 x) / S(J y)}_{s}^{0}$} & \multirow{2}{*}{$\begin{array}{c}B(3 y) / B(\text { Jy })^{C} \\
E\end{array}$} & \multirow{2}{*}{$\begin{array}{c}3(d x) / 3(5 x)^{d} \\
s . t\end{array}$} & \multirow{2}{*}{$\begin{array}{l}T(2 x)^{e} \\
(k)\end{array}$} & \multirow{2}{*}{$\begin{array}{l}T(a x) \\
(k)\end{array}$} \\
\hline & a & 0 & & & & & & & & \\
\hline$\frac{1}{2}$ & $\begin{array}{l}\text { Jup } \\
\text { Jup } \\
\text { Jup } \\
\text { Jup } \\
\text { jup }\end{array}$ & $\begin{array}{l}\text { Mars } \\
\text { Mars } \\
\text { Mars } \\
\text { Mars }\end{array}$ & $\begin{array}{l}1979 \\
1979 \\
1980 \\
1980\end{array}$ & $\begin{array}{l}\text { Nov } 27 \\
\text { Nov } 29 \\
\text { Feo } 21 \\
\text { Fed } 22\end{array}$ & $\begin{array}{l}\mathrm{CH} 3 \\
\mathrm{CH} 3 \\
\mathrm{CH} 3 \\
\mathrm{CH} 3 \\
\mathrm{CH} 3\end{array}$ & $\begin{array}{l}1.025=0.040 \\
1.088 \pm 0.018 \\
1.090 \pm 0.040 \\
1.036 \pm 0.050\end{array}$ & $\begin{aligned} 0.710 & \pm 0.009 \\
0.705 & \pm 0.009 \\
0.690 & =0.049 \\
(0.707 & \pm 0.019)^{1}\end{aligned}$ & $\begin{array}{l}0.727 \div 0.030 \\
0.757 \div 0.016 \\
0.752 \div 0.060 \\
0.732 \div 0.040\end{array}$ & $\begin{array}{l}213 \\
213 \\
213.5 \\
213.5\end{array}$ & $\begin{array}{l}160.0=5.3 \\
167.3=3.1 \\
164.9 \pm 11.7 \\
161.0=7.3 \\
165.5 \pm 2.59\end{array}$ \\
\hline$j$ & $\begin{array}{l}\text { juo } \\
\text { jup } \\
\text { juo }\end{array}$ & $\begin{array}{l}\text { Mars } \\
\text { Mars }\end{array}$ & $\begin{array}{l}1980 \\
1980\end{array}$ & $\begin{array}{ll}\text { Fed } & 21 \\
\text { Fed } & 22\end{array}$ & $\begin{array}{l}\text { C-4 } \\
\text { O-14 } \\
\text { O-44 }\end{array}$ & $\begin{array}{l}0.332 \pm 0.004 \\
0.870 \pm 0.030\end{array}$ & $\begin{aligned} 0.690 & \pm 0.049 \\
(0.707 & \pm 0.019)^{f}\end{aligned}$ & $\begin{array}{l}0.574 .=0.041 \\
0.515=0.027\end{array}$ & $\begin{array}{l}213.5 \\
213.5\end{array}$ & $\begin{array}{l}128.9 \pm 8.1 \\
137.1 \pm 5.1 \\
134.5 \pm 4.59\end{array}$ \\
\hline $\begin{array}{l}7 \\
3\end{array}$ & $\begin{array}{l}\text { juo } \\
\text { jup } \\
\text { jup }\end{array}$ & $\begin{array}{l}\text { Mars } \\
\text { Mars }\end{array}$ & $\begin{array}{r}1979 \\
1979\end{array}$ & $\begin{array}{l}\text { itov } 27 \\
\text { itov } 29\end{array}$ & $\begin{array}{l}104 \\
104 \\
\mathrm{NO4}\end{array}$ & $\begin{array}{l}0.942=0.019 \\
0.980 \pm 0.010\end{array}$ & $\begin{array}{l}0.710=0.009 \\
0.705=0.009\end{array}$ & $\begin{array}{l}0.509=0.016 \\
0.59 \mathrm{i}=0.0 \mathrm{il}\end{array}$ & $\begin{array}{l}213 \\
213\end{array}$ & $\begin{array}{l}146.3=3.2 \\
151.3 \pm 2.2 \\
149.9=2.6^{9}\end{array}$ \\
\hline $\begin{array}{l}9 \\
10 \\
11 \\
12\end{array}$ & $\begin{array}{l}\text { Jup } \\
\text { Jup } \\
\text { Jup } \\
\text { Jup } \\
\text { Jup }\end{array}$ & $\begin{array}{l}\text { Mars } \\
\text { Mars } \\
\text { Mars } \\
\text { Mars }\end{array}$ & $\begin{array}{l}1979 \\
1979 \\
1980 \\
1980\end{array}$ & $\begin{array}{l}\text { Nov } 27 \\
\text { Nov } 28 \\
\text { Feb } 21 \\
\text { Feo } 22\end{array}$ & $\begin{array}{l}\text { OA5 } \\
\text { CH5 } \\
\text { QH5 } \\
\text { CH5 } \\
\text { O-15 }\end{array}$ & $\begin{array}{l}1.090 \pm 0.013 \\
1.105 \pm 0.030 \\
1.053 \pm 0.029 \\
1.096 \pm 0.040\end{array}$ & $\begin{aligned} 0.710 & \pm 0.009 \\
0.705 & \pm 0.009 \\
0.590 & \pm 0.049 \\
(0.707 & \pm 0.019)^{f}\end{aligned}$ & $\begin{array}{l}0.774 \pm 0.013 \\
0.779 \pm 0.023 \\
0.727 \pm 0.055 \\
0.775 \pm 0.035\end{array}$ & $\begin{array}{l}213 \\
213 \\
213.5 \\
213.5\end{array}$ & $\begin{array}{l}167.2 \pm 2.5 \\
168.2 \pm 4.7 \\
158.1 \pm 11.1 \\
167.3=7.1 \\
167.1 \pm 2.1^{9}\end{array}$ \\
\hline $\begin{array}{l}13 \\
14 \\
\vdots 5 \\
15\end{array}$ & $\begin{array}{l}\text { Sat } \\
\text { Sat } \\
\text { jat } \\
\text { Sat } \\
\text { Sat }\end{array}$ & $\begin{array}{l}\text { Mars } \\
\text { Mars } \\
\text { Mars } \\
\text { Mars }\end{array}$ & $\begin{array}{l}1979 \\
1979 \\
1980 \\
1980\end{array}$ & $\begin{array}{l}\text { Nov } 27 \\
\text { Nov } 28 \\
\text { Feo } 21 \\
\text { Feo } 22\end{array}$ & $\begin{array}{l}\mathrm{CH3} \\
\mathrm{CH} \\
\mathrm{CH} \\
\mathrm{CH} \\
\mathrm{OH} \\
\mathrm{CH}\end{array}$ & $\begin{array}{l}0.924=0.007 \\
0.931 \div 0.003 \\
0.897 \pm 0.027 \\
0.915 \pm 0.30\end{array}$ & $\begin{aligned} 0.525 & \pm 0.006 \\
0.526 & \pm 0.009 \\
0.471 & \pm 0.037 \\
(0.524 & \pm 0.015)^{8}\end{aligned}$ & $\begin{array}{l}0.485 \pm 0.007 \\
0.490 \pm 0.009 \\
0.422 \pm 0.036 \\
0.479 \pm 0.021\end{array}$ & $\begin{array}{l}213 \\
213 \\
213.5 \\
213.5\end{array}$ & $\begin{array}{l}112.9 \pm 1.4 \\
113.9 \pm 1.8 \\
10 C .3 \pm 7.1 \\
112.0 \pm 4.1 \\
112.9 \pm 1.19\end{array}$ \\
\hline $\begin{array}{l}17 \\
18\end{array}$ & $\begin{array}{l}\text { Sat } \\
\text { Sat } \\
\text { Sat }\end{array}$ & $\begin{array}{l}\text { Mars } \\
\text { Mars }\end{array}$ & $\begin{array}{l}1980 \\
1980\end{array}$ & $\begin{array}{ll}\text { Fed } & 21 \\
\text { Fed } 22\end{array}$ & $\begin{array}{l}\mathrm{CH} 4 \\
\mathrm{CH} 4 \\
\mathrm{OH} 4\end{array}$ & $\begin{array}{l}0.970 \pm 0.008 \\
0.953 \pm 0.020\end{array}$ & $\begin{aligned} 0.471 & \pm 0.037 \\
(0.524 & \pm 0.015)^{f}\end{aligned}$ & $\begin{array}{l}0.457 \pm 0.026 \\
0.499 \pm 0.018\end{array}$ & $\begin{array}{l}213.5 \\
213.5\end{array}$ & $\begin{array}{l}105.6 \pm 7.1 \\
114.0 \pm 3.5 \\
112.3 \pm 3.2^{9}\end{array}$ \\
\hline $\begin{array}{l}19 \\
20\end{array}$ & $\begin{array}{l}\text { Sat } \\
\text { Sat } \\
\text { Sat }\end{array}$ & $\begin{array}{l}\text { Mars } \\
\text { Mars }\end{array}$ & $\begin{array}{l}1979 \\
1979\end{array}$ & $\begin{array}{l}\text { Nov } 27 \\
\text { Nov } 29\end{array}$ & $\begin{array}{l}\mathrm{NO4} \\
\mathrm{NO4} \\
\mathrm{NO4}\end{array}$ & $\begin{array}{l}1.020 \pm 0.007 \\
1.043 \pm 0.005\end{array}$ & $\begin{array}{l}0.525 \pm 0.006 \\
0.526 \pm 0.009\end{array}$ & $\begin{array}{l}0.536 \pm 0.007 \\
0.549 \pm 0.010\end{array}$ & $\begin{array}{l}213 \\
213\end{array}$ & $\begin{array}{l}120.3 \pm 1.4 \\
: 22.9 \pm 2.0 \\
122.2 \pm 1.19\end{array}$ \\
\hline $\begin{array}{l}2 ! \\
22 \\
23 \\
24\end{array}$ & $\begin{array}{l}\text { Sat } \\
\text { Sat } \\
\text { Sat } \\
\text { Sat } \\
\text { Sat }\end{array}$ & $\begin{array}{l}\text { Mars } \\
\text { Mars } \\
\text { Mars } \\
\text { Mars }\end{array}$ & $\begin{array}{l}1979 \\
1979 \\
1980 \\
1980\end{array}$ & $\begin{array}{ll}\text { Nor } & 27 \\
\text { iNor } & 28 \\
\text { Feb } & 21 \\
\text { Feo } & 2 ?\end{array}$ & $\begin{array}{l}\text { C.15 } \\
\text { CH5 } \\
0+15 \\
0+5 \\
\text { Ci5 }\end{array}$ & $\begin{array}{l}1.160 \pm 0.017 \\
1.317 \pm 0.029 \\
1.204 \pm 0.016 \\
1.174=0.030\end{array}$ & $\begin{aligned} 0.525 & \pm 0.006 \\
0.526 & \pm 0.009 \\
0.471 & \pm 0.037 \\
(0.524 & \pm 0.015)^{f}\end{aligned}$ & $\begin{array}{l}0.609 \pm 0.011 \\
0.693 \pm 0.019 \\
0.567 \pm 0.045 \\
0.515 \pm 0.024\end{array}$ & $\begin{array}{l}213 \\
213 \\
213.5 \\
213.5\end{array}$ & $\begin{array}{l}: 33.3=2.2 \\
150.3=3.9 \\
125.5=9.1 \\
\vdots 35.3=4.9 \\
137.1 \pm 4.19\end{array}$ \\
\hline 25 & ur & juo & 1981 & Mar ! & $\mathrm{CH} 3$ & $0.780=0.034$ & $0.328=0.006$ & $0.303=0 . \mathrm{JI}$ & $165.5=2.5$ & $62.4=2.3$ \\
\hline : & Ur & Jup & $199 !$ & $\operatorname{Mar}$ i & $\mathrm{CH} 4$ & $1.259=0.083$ & $0.388=0.006$ & $0.489=0.033$ & $134.5 \pm 1.5$ & $13 . \therefore=1.3$ \\
\hline 7 & ur & Juo & 1981 & Mar 1 & CAS & $1.276=0.101$ & $0.289=0.006$ & $0.295=0.040$ & $167.2=2 . \therefore$ & $37.9=5.4$ \\
\hline & ivep & Jup & 1981 & $\operatorname{Mar} 1$ & $\mathrm{CH} 3$ & $0.330=0.042$ & $0.372=0.006$ & $0.20 ?=0.015$ & $165.5 \pm 2.5$ & $63.3: 2.5$ \\
\hline & ike & Juo & 1981 & Mar : & $\mathrm{CH} 4$ & $1.191=0.178$ & $0.372=0.006$ & $0.433=0.067$ & $134.5=4.5$ & $67.5=3.4$ \\
\hline 0 & ikp & jup & 1981 & Mar 1 & C.t5 & $1.128=0.151$ & $0.372=0.006$ & $0.420=0.05 i$ & $167.1=2.1$ & $76.1 \div 9.0$ \\
\hline
\end{tabular}

apilier y is Ciz in every case.

${ }^{S} S(a x) / S(a y)=$ ratio of slynal from glanet a with filter $x$ (column \$) so signal from planet a with filter y (Ct2), et:s. The siynal ratios have jeen corres:ea to $1 \mathrm{~mm} l$ ine-of-signt water vapor for filters CH2, CH3, CH4, NOA, and CH5. and :O

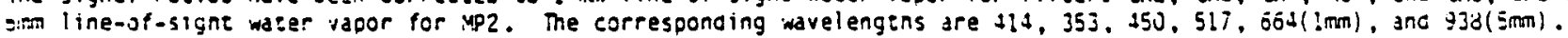

${ }_{g}(3 y)=$ origneness of planee a with filter $y$, ece. The values of the origniness ratios are taxen from idole ll colunn (11) using data from the saine dates except as otherwise noted (footnote $f$ ).

¿coluan (5) cines column (6).

eAssumed oriyneness temperacure of plane: 0 , filicer $x$ based on Wriynt's model (see Secion III of text), wnere plane: 0 is Mars, and on the results snown in Table $V$, where planet $b$ is Jupiter.

'iveraye of earlier aata on $B(a y) / B(b y)$ or same plare:s with error mulisipliea oy 3 . (No direc: neasurenen: af (iay)/B(Dy) on Feoruary 22.)

Yiveraye of vaives for same planet ard filter. 
anc $n$

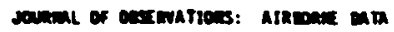

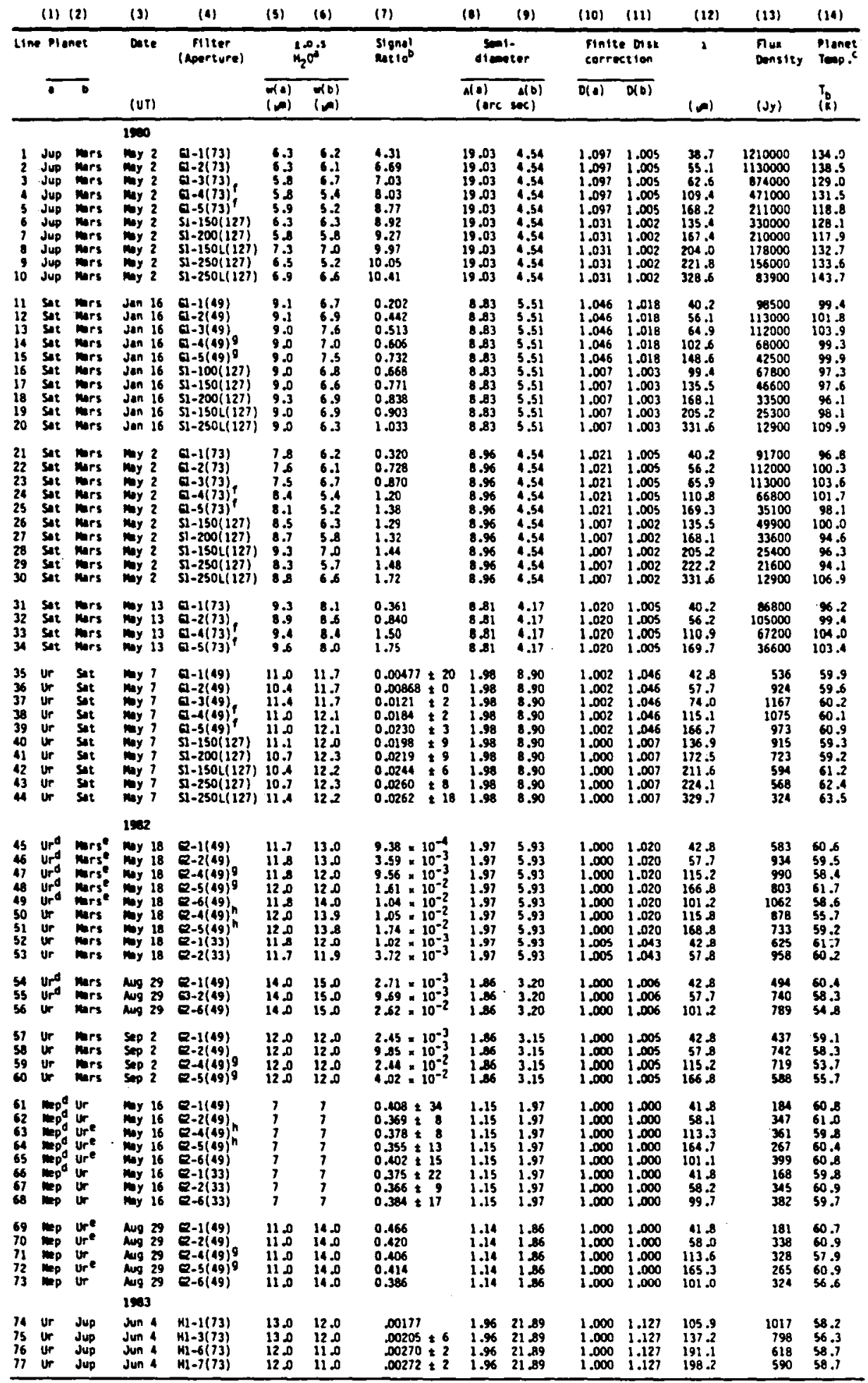

Line of sight wter vapor based on a borestght rwiometer for línes 1 to 44 and on a zenten rediometer and secant $z$ for lines is to 73 . On My 16 (11nes 61 to 68 ) the zenith radionter fallod before the planet observations. lines is to 73 . On Wy $16(1 \mathrm{lnes} 61$ to 68$)$ the zenith

b me errors in the least significant ofigits are shom in cases there repeated easureaents peraitted statistical error analysis.

cestiate the statistical errors (not incluoing the errors in the mars calibration) at $1.5 k$ for Juplter, Saturn ano uranus. ond 3.5k for motune.

diso coservations of planet averaged.

- To coservations of planet b averaged.

The short-wavelength blocking filter ws keflon.

Por these ceasurcaents fllters and 5 were used without any feflon or OF, for short-wavelength blocking.

The dats have been corrected taking into account asll measured leak at? 20 .

"The snort-welength blocking filter as $O F_{2}$. 
TABLE $V$

BRIGHTNESS TEMPERATURES ${ }^{\mathrm{a}}$

(Sumnary of Data from Tables II, III, and IV)

\begin{tabular}{|c|c|c|c|c|c|c|c|c|c|}
\hline \multirow[t]{2}{*}{ Line } & Jupiter & & \multicolumn{2}{|c|}{ Saturn } & \multicolumn{2}{|c|}{ Uranus } & \multicolumn{3}{|c|}{ Neptune } \\
\hline & $\left({ }_{\mu}^{\lambda}\right)$ & $\begin{array}{l}\text { Temp } \\
(x)\end{array}$ & $\stackrel{\lambda}{\lambda(m)}$ & $\begin{array}{l}\text { Temp } \\
(K)\end{array}$ & $\stackrel{\lambda}{\lambda(u)}$ & $\begin{array}{l}\text { Temp } \\
(\mathrm{x})\end{array}$ & $\stackrel{\lambda}{(\mu m)}$ & & K) \\
\hline 1 & 38.7 & 134.0 & 40.2 & $97.5 \pm 1.7^{b}$ & 42.8 & $60.3 \pm 0.7^{c}$ & 41.8 & 60.6 & $\pm 0.5^{c}$ \\
\hline 2 & 55.1 & 138.5 & 56.2 & $100.5 \pm 1.2^{b}$ & 57.7 & $59.2 \pm 0.7^{c}$ & 58.1 & 60.9 & $\pm 0.1^{c}$ \\
\hline 3 & 62.6 & 129.0 & 65.4 & $103.7 \pm 0.2^{b}$ & 74.0 & 60.2 & 100.8 & 58.9 & $\pm 2.1^{c}$ \\
\hline 4 & 109.4 & 131.5 & 99.4 & 97.3 & 102.8 & $57.2 \pm 2.1^{b}$ & 113.4 & 58.9 & $\pm 1.3^{b}$ \\
\hline 5 & 135.4 & 128.1 & 102.6 & 99.3 & 115.3 & $57.0 \pm 2.8^{b}$ & 165.0 & 60.7 & $\pm 0.4^{b}$ \\
\hline 6 & 168.0 & $118.4 \pm 0.6^{b}$ & 110.8 & $102.9 \pm 1.6^{b}$ & 137.0 & $57.8 \pm 2.1^{b}$ & & & \\
\hline 7 & 204.0 & 132.7 & 135.5 & $98.8 \pm 1.7^{b}$ & 167.3 & $59.4 \pm 2.7^{b}$ & & & \\
\hline 8 & 221.8 & 133.6 & 148.6 & 99.9 & 172.5 & 59.2 & & & \\
\hline 9 & & & & & 191.1 & 58.7 & & & \\
\hline 10 & & & & & 198.2 & 58.7 & & & \\
\hline $11^{\circ}$ & 328.6 & 143.7 & 168.6 & $97.2 \pm 3.3^{b}$ & 211.6 & 61.2 & & & \\
\hline 12 & & & 205.2 & $97.2 \pm 1.3^{b}$ & 224.1 & 62.4 & & & \\
\hline 13 & & & 222.2 & 94.1 & 329.7 & 63.5 & & & \\
\hline 14 & & & 331.6 & $108.4 \pm 2.1^{b}$ & & & & & \\
\hline 15 & 353 & $165.5 \pm 2.5$ & 353 & $112.9 \pm 1.1$ & 353 & $62.4 \pm 2.3$ & 353 & 63.3 & \pm 2.5 \\
\hline 16 & 414 & $155.3 \pm 1.3$ & 414 & $119.2 \pm 1.2$ & 414 & $70.1 \pm 1.3$ & 414 & 67.9 & \pm 1.2 \\
\hline 17 & 450 & $135 \pm 5$ & 450 & $112.3 \pm 3.2$ & 450 & $73 \pm 5$ & 450 & 68 & \pm 8 \\
\hline 18 & 517 & $149.9 \pm 2.6$ & 517 & $122.2 \pm 1.1$ & & & & & \\
\hline 19 & 664 & $167.1 \pm 2.1$ & 664 & $137 \pm 4$ & 664 & $88 \pm 6$ & 664 & 76 & \pm 9 \\
\hline 20 & 968 & \pm 10 & 968 & $134.5 \pm 3.2$ & 968 & $94.5 \pm 2.3$ & 968 & 103 & \pm 7 \\
\hline
\end{tabular}

${ }^{a}$ None of the errors shown in this table includes the uncertainty in the Mars calibration. Errors for IRTF data ( 1 ines 13-18) are computed as specified in Appendix D. Errors shown for KAO data (lines 1-12) are standard deviations of two or more measurements from Table IV where the effective wavelengths fall within a range of $2 \mathrm{\mu m}$. (See foctnotes $b$ and $c$ concerning weighting.) The mean of the 19 errors for KAO data is $1.5 \mathrm{~K}$ (see discussion in text).

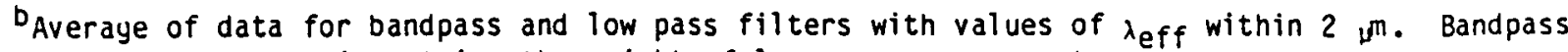
measurements are given twice the weight of low pass measurements.

CAveraye of data for $33^{\prime \prime}$ and $49^{\prime \prime}$ apertures ( $\lambda_{\text {eff }}$ within $2 \mathrm{um}^{\mathrm{m}}$ ). To allow for possible guiding errors the $33^{\prime \prime}$ measurements are given half the weight of $49^{\prime \prime}$ measurements. 




-For sale by the National Technical Information Service, Springfield, Virginia 22161 
End of Document 